\title{
Institute for Advanced Development Studies
}

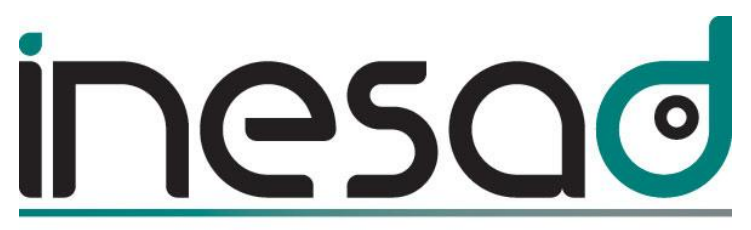

$10 / 2015$

The Bounty of the Sea and Long-Run Development

\author{
by: \\ Carl-Johan Dalgaard \\ Anne Sofie B.Knudsen \\ Pablo Selaya \\ Development Research Working Paper Series \\ $10 / 2015$
}

September 2015

The views expressed in the Development Research Working Paper Series are those of the authors and do not necessarily reflect those of the Institute for Advanced Development Studies. Copyrights belong to the authors. Papers may be downloaded for personal use only. 


\title{
The Bounty of the Sea and Long-Run Development*
}

\author{
Carl-Johan Dalgaard $\quad$ Anne Sofie B. Knudsen Pablo Selaya ${ }^{\dagger}$
}

September 25, 2015

\begin{abstract}
What is the long run impact on development from differences in subsistence strategies during preindustrial times? Whereas this question has been explored from the point of view of agriculture, remarkably little attention has been paid to the complementary strategy of relying on marine resources. As a step towards closing this gap, we construct an index - "the Bounty of the Sea index - which captures the potential abundance of exploitable marine fish that individual countries have had access to, and proceed to explore its correlation with economic development. Our analysis reveals that a greater Bounty of the Sea stimulated pre-industrial development, and that countries inhabited by people with ancestry in regions with abundant marine resources are richer today. Probing possible underlying reasons, we find that populations with ancestry in regions rich in marine resources differ from societies with a purely agrarian legacy in terms of institutions, cultural values and average personality traits.
\end{abstract}

Keywords: Subsistence strategy; Fishing; Economic Development; Personality; Culture; Institutions JEL classification: O11, O13, O47, O57

\footnotetext{
${ }^{*}$ We would like to thank Quamrul Ashraf, Davide Cantoni, Matteo Cervellati, Melissa Dell, Oded Galor, Robert Klemmensen, Marc Klemp, Omer Licandro, Anastasia Litina, Stelios Michalopoulos, Nathan Nunn, Karl Gunnar Persson, David Weil, Asger Wingender and seminar participants at the Barcelona Summer Forum: "Towards Sustained Economic Growth: Geography, Demography and Institutions"; the CESifo workshop on "the Long Shadow of History"; the workshop on "Deep Rooted Factors in Comparative Economic Development" at Brown University; the 6th Annual Workshop on Growth, History and Development at the University of Southern Denmark, and, at the University of Luxemburg. Errors are ours. Pablo Selaya furthermore thanks the Danish Council for Independent Research for funding this research, and IQSS and MCZ at Harvard University for hospitality and help with access to data.

${ }^{\dagger}$ Contract information. Dalgaard: Department of Economics, University of Copenhagen and CEPR. Knudsen and Selaya: Department of Economics University of Copenhagen.
} 


\section{Introduction}

What is the impact of the subsistence strategy during pre-industrial times on long-run development? A sizable literature has analyzed this question from the point of view of agriculture. For example, studies have explored the ramifications of the timing of the introduction of agriculture (the Neolithic revolution) as well as a variety of aspects related to the type of agricultural activities undertaken. ${ }^{1}$ Meanwhile, the role played by the exploitation of "the Bounty of the Sea" - fishing - has recieved essentially no attention in the literature on comparative economic development. ${ }^{2}$ This is surprising since fishing has been a viable subsistence strategy for a very long time: during the Mesolithic (and likely during the Paleolithic as well) fishing was an alternative (or complement) to inland hunting and gathering, and after the Neolithic Revolution it remained as an alternative (or complement) to agriculture. ${ }^{3}$

In this paper we ask whether societies that could benefit from a rich bounty of the sea have followed a different development trajectory than societies which had to rely almost exclusively on agriculture. There are good reasons why this could have been the case, as discussed below. Aside from the obvious nutritional benefits from access to marine resources (conditional on land-based resources), a rich bounty of the sea has likely contributed to long-run development through the emergence of cities and growth of international trade. Consequently, due to its impact on the structure of the economy, a rich maritime environment may have helped shape the outlook of people in terms of e.g. values and preferred institutions.

Accordingly, we probe the answer to a range of questions pertaining to the long-run impact of the bounty of the sea: Did rich maritime ressources, conditional on inland charactaristics, lead to faster population growth during pre-Industrial times? Did the mode of subsistence influence the composition of individual populations in terms of average personality traits or cultural values? Did it leave an imprint on formal institutions? Do we see an impact on contemporary development from the bounty of the sea? The empirical analysis in this paper suggests the answer to all of these questions is in the affirmative.

At the heart of this study is a new index : "The Bounty of the Sea index". Conceptually, this index is similar in spirit to indices speaking to the suitability of land for agriculture. The underlying data derive from the AquaMaps database, which contains information about the habitat suitability of most species of marine fish in the world. The raw data is provided at a 0.5 degree latitude by 0.5 degree longitude resolution, and reports the probability that any specific species can survive under local geographical conditions, such as

\footnotetext{
${ }^{1}$ On the timing of the Neolithic and development, see Diamond (1997); Olsson and Hibbs (2005); Putterman (2008), Ashraf and Galor (2011) and Chanda et al. (2014). The land suitability for agriculture and its impact on development has been examined for instance by Masters and McMillan (2001). On the type of crops and long term development, see e.g. Engermann and Sokolof (2002) and Easterly (2001). On rain fed vs irrigation fed crops, see e.g. Bentzen et al. (2015). On herding vs agriculture, see Michalopoulos et al. (2014).

${ }^{2}$ Previous work has examined the implications of having access to sea or navigatable river (see e.g., Rappaport and Sachs, 2003). In the present paper we draw attention to the fact that what is below the surface of the sea seems to matter as well.

${ }^{3}$ See Erlandson (2001) for an overview of the archeological evidence on early human exploitation of aquatic ecosystems.
} 
sea depth and temperature of the local ocean. Hence, the underlying data speaks to the potential presence of a specific species, not whether it is actually found in a particular location. The raw data are available for more than 20,000 species. Yet many species are hard to exploit by humans, and some may even be poisonous. Hence, we proceed by selecting a subset, and propose a baseline index based on the unweighted average survival probability of the 15 most important species in terms of worldwide landings during the 1950s, which is the earliest period for which we have data on global landings by species; these 15 species alone accounted for more than 50\% of total global landings between 1950 and 1959. The baseline index is aggregated to the country level based on each individual nations' Exclusive Economic Zone. ${ }^{4}$ In order to check the robustness of our results to different measures of the bounty of the sea, we provide alternative indices that are distinguishable by how the relevant species are selected; how the index is aggregated to the country level; and also in terms of the weighting strategy. In the latter respect, we compute indices where each individual species is weighted by its nutritional characteristics: calories, fat, and protein, respectively.

With the Bounty of the Sea (BoS) index in hand, we subsequently provide a series of checks of whether it sucessfully predicts actual exploitation of marine ressources. Specifically, we examine the explanatory power of the index vis-á-vis fish landings in a cross-section of countries after the 1950s, where the globally most important fish species differ substantially from those selected for the index. We also examine whether the index appears to be relevant during the period 1900-1940, where we have data on landings for a smaller group of countries. In a seperate set of tests, we examine whether the index also explains the extent to which local communities in different regions of the world have relied on fishing for subsistence. This seems to be the case both when we employ regional data for the North Atlantic area during the 19th century, and when we exploit data pertaining to traditional societies recorded in the Standard Cross-Cultural Sample of Murdock's (1967) Ethnographic Atlas. Overall, the tests paint a coherent picture, consistently supporting the relevance of the developed index for the purpose at hand.

Against this background, we take a first step in gauging the long-run impact from the Bounty of the Sea on economic development. We begin by examining the explanatory power of the index for population density in the pre-Columbian era, for a large cross-section of countries. ${ }^{5}$ Controlling for land suitability for agriculture, along with a set of auxiliary geographical and climatic covariates of productivity, we find that the BoS index is positively correlated with population density in 1500 C.E. While our estimates suggest that agriculture had an economically more significant impact on population density than fishing, the point estimate for the BoS index is of a similar order of magnitude. This result is robust to the further inclusion of a range of well established determinants of economic development during the pre-Columbian period.

\footnotetext{
${ }^{4}$ The Exclusive Economic Zone is a sea zone prescribed by the United Nations Convention on the Law of the Sea over which a state has special rights regarding the exploration and use of marine resources. It stretches from the baseline out to 200 nautical miles from its coast.

${ }^{5}$ We focus on population density for Malthusian reasons. See e.g. Ashraf and Galor (2011) or Dalgaard and Strulik (2015) for a similar approach and dicussion.
} 
Subsequently, we turn our attention to the contemporary era, thereby asking if the BoS index remains a correlate of economic development in the 21st century. While the suitability of land for agriculture turns out to be negatively correlated with GDP per capita today, the BoS index remains positively correlated with contemporary levels of economic development. This finding suggests that societies that could rely on the bounty of the sea for subsistence (or at least as a complement to agriculture) have indeed followed a different development trajectory than fully agro-based societies. ${ }^{6}$

At first sight these results may seem puzzling. In most places around the world today fishing activities do not account for a very substantial share of current GDP; just as is the case for agriculture. Hence, one might suspect that the real reason why indicators of the potential for various pre-industrial subsistence strategies nevertheless carry significant explantory power in terms of living standards today is because they have shaped the outlook of people: their personality traits, their culture, and perhaps also the sort of institutions they favor. In fact, such links can be motivated by existing work in anthropology, political science as well as in economics, as detailed below.

As a result, we proceed by examining whether ancestry adjusting the BoS index improves its performance, following Putterman and Weil (2010). If indeed the BoS index exerts its contemporary influence via factors that are embodied in individuals (such as cultural values) we would expect to see a more economically significant link emerge when we invoke the ancestry adjusted index, than when we rely on the unadjusted counterpart. Our analysis reveals that this is indeed the case; the ancestry adjusted BoS index is considerably more economically significant in explaining GDP per capita than the unadjusted index. Moreover, when both indices are introduced simultanously in the regression model, only the ancestry adjusted index remains significant. Accordingly, we infer that it is not the current geographic environment of a country that seems to matter to present economic development, but rather the geographic and maritime environment of the ancestors of the current population. These results are robust to a very demanding set of controls, as documented below.

As a further check of these results, we explore the link between the ancestry adjusted BoS index and a broad set of - non-geographic - fundamental determinants of productivity (Acemoglu, 2008; Ch. 4). Specifically, we examine the link between the BoS index and measures of institutions, cultural values as well as mean score values for the so-called "Big Five" personality traits. In each dimension we find that marine ressources, appropriately ancestry adjusted, carries significant explantory power, consistent with the reduced form results. Moreover, the uncovered correlations appear consistent with priors based on existing research in anthropology, political science and economics.

\footnotetext{
${ }^{6}$ The negative link between measures of agricultural productivity and contemporary development is well known. Litina (2013) argues the "reversal" of the impact from agricultral productivity was caused by differential cultural adaptations across populations exposed to different levels of land productivity. Olsson and Paik (2014) find that an early Neolithic revolution, while initially being an advantage, eventually stifled economic development. The authors propose an institutional explanation for this reversal.
} 
The present study contributes to the literature on long term persistence in economic development; recent surveys are provided in Nunn (2014) and Wacziarg and Spolaore (2013). More specifically, it contributes to the literature which argues, similar to what the present study suggests, that pre-industrial subsistence strategies have left a lasting imprint on development, which still can be detected today. Important contributions include Durante (2010), Michalopoulos (2012), Bentzen et al. (2015), Alesina et al. (2013), Littina (2013), Galor and Özak (2014), Michalopoulos et al. (2014), and Talhelm et al. (2014).

The rest of the paper is organized as follows. In Section 2 we discuss why the bounty of the sea might matter for long term economic development. In Section 3 we describe the construction of the Bounty of the Sea Index after which we present a number of validation exercises in Section 4. Section 5 presents the main findings of the paper, which pertain to the relationship between the bounty of the sea and economic development during pre-industrial times and in the industrial era. In lieu of our main findings in Section 5, Section 6 studies the link between our index and broad-based measures of institutions, culture and personality traits. We conclude the paper in Section 7.

\section{Why Would the Bounty of the Sea Matter?}

\subsection{Nutrition}

The most direct way that rich marine ressources could influence development is through nutrition. Ceteris paribus, places with access to rich martime fishing grounds have had the opportunity to support a greater population density, conditional on inland resources. This would especially be true during historical and pre-historical times, where the ability to transport food was rather limited compared to today.

Fish is very rich in protein, making it a vital dietary component (see e.g., Tidwell and Allan, 2001). Moreover, at the level of micronutrients, fish is the best dietary source of Vitamin D, which works to prevent a range of chronic diseases (Ruxton, 2011). The dietary importance of marine fish in ancient times is difficult to gauge, but in the Mediterranean and Black Sea area, fish were by all accounts a more important source of food than other forms of meat during antiquity (Holm et al., 2010). ${ }^{7}$ Even today, fish intake makes up for nearly 20 pct of the worlds animal protein intake on average (FAO, 2014).

Accordingly, if access to a rich bounty of the sea helped support greater population densities in some parts of the world, one may envision additional benefits in terms of e.g. division of labor and technology adoption, along Smith-Boserupian lines.

\footnotetext{
${ }^{7}$ In fact, severe depletion of marine species, in this region of the world, started occuring more than 2000 years B.P., testifying to the non-negligible role played by fishing during the Neolithic period (Lotze et al., 2006).
} 


\section{$2.2 \quad$ International trade, market expansion and cities}

A rich bounty of the sea may also have had a more indirect influence by instigating the emergence of cities and trade. If so, the presence of the resource would have further implications beyond those narrowly connected with the fisheries themselves and the potential nutritional benefits. In some instances this sort of "amplification" of the impact from marine resources would be gradual. Initially, rich marine resources may have drawn people to the sea for the purpose of hunting and gathering. Coastal urban centers may have emerged. Over time the maritime orientation would create knowledge about boat-making and navigation, eventually enabling long distance trade. Initially due to the fish trade, but perhaps eventually involving trade in other commodities as well. ${ }^{8}$ While these sort of processes are difficult to track during pre-historical times, it is possible for the historical period.

\subsubsection{The Old World}

During the 10th century the exploitation of the bounty of the sea expands appreciably in Western Europe; the period is sometimes dubbed the "fish event horizon" (see e.g., Barret et al., 2004a,b). Multiple factors may have played a role in unleashing the elevated importance of fish from the sea. First, the expanding population of Europe, prompted by higher agricultural yields during the Medieval Warm Period, increasingly depleted inland fishing resources, thereby creating demand for new sources of (animal) protein (e.g., Bolster, 2012, Ch. 1). Second, during the Medieval period the Church encouraged fasting for a substantial part of the year during which meat was not allowed to be consumed. Fish, however, was not considered "meat". This too surely stimulated demand. ${ }^{9}$ Third, a particular group of warriors and traders may have played a separate role: The Vikings. Bolster (2012, p. 25) explains:

Viking invaders [...] became the fishmongers to Britain and the Continent, providing technology and expertise that made deep sea fishing possible. As early as the eighth century Scandinavians were catching, drying and distributing Codfish from the Norwegean Sea in a pre-commercial "web of obligation and exchange" [...] Stockfish became the staple of Viking civilizations and the food supporting notoriously long voyages. And it was the first sea fish traded over extended distances in Northern Europe, predating the Hanseactic League's Herring business.

\footnotetext{
${ }^{8}$ For example, trade in fish produce was arguably quite extensive during antiquity in the Mediterranean area. Some fish were salted and transported, but other landings went into the production of a fish sauce called "garum", which required relatively large production sites. The sauce was a commonplace dietary element throughout the Roman Empire. In terms of economic scale, one assessments of amphoras that were used to transport the produce over longer distances suggests that about $70 \%$ was used for wine, $20 \%$ was olive oil and $10 \%$ garum (see Holm et al., 2010, and references cited therein).

${ }^{9}$ In fact, during nearly 150 days per year fish would be the only kind of meat that could be consumed, by an observing Christian during the late Medieval period (e.g., Hoffman, 1996).
} 
Knowledge of the new marine opportunities could easily spread from Viking diasporas in Faroes, Shetland, Orkneys, Hebrides, Ireland, Iceland and Greenland as well as from conquered parts of England and France. Over time trade in marine fish gradually expands in Europe, and serves to influence the emergence of markets and urban areas.

One example is found in the Medieval orgins of Copenhagen, the capital of Denmark. Given its location and history, there is little reason to doubt that the city owes its relative importance to its proximity to the sea and to trade. ${ }^{10}$ But it turns out that the rise of the city in importance almost surely was critically influenced by the rich fishing grounds in the Sound ("Øresund"), the small strait that seperates Denmark from Sweden today. To be sure, during the late medieval period the fisheries around Copenhagen appear to have been remarkably productive. Saxo, in his Introduction to the history of Denmark from the early 13th century, writes that: "The whole Sound is apt to be so thronged with fish that any craft which strikes on them is with difficulty got off by hard rowing, and the prize is captured no longer by tackle, but by simple use of the hands..". It seems unlikely that this passage is to be taken literately but rather as conveying the percieved importance of the resource at the time. In fact, recent historical studies have made probable, based on medieval tax records, that Danish exports of herring at its peak around 1400 C.E. amounted to about 27,000 tonnes of fresh fish per year, from the Sound alone (Holm, 1998). In terms of export earnings, the contribution from Sound herring landings appears to have exceeded national export earnings from agriculture (grain and oxen) by nearly a factor of two (Holm, 1998). Initially, the trade flows involved the intervention of Hansean cities (Lübeck in particular) who both provided the salt for the preservation process, and were instrumental in selling off the product to other parts of Europe. Eventually, however, Danish merchants came to play an increasing role in the latter respect. Moreover, the trade in fish also served to draw in other merchants to Copenhagen. At the dawn of the 16th century, Copenhagen was the most important city in the country, as witnessed by the fact that it had become the royal residence. During the 17th century, however, herring lost its significance as an export commodity. ${ }^{11}$ Nevertheless, Copenhagen remained the capital of the country, and a focal point for foreign trade. ${ }^{12}$

\footnotetext{
${ }^{10}$ In the earliest records from the 11th century, Copenhagen, or "København" as it is called in Danish, is referred to as "Hafn" ("Harbor"), which within two centuries develops into "Køpmannæhafn", or "the habor of merchants", and ultimately into "København". Being located at the center of the Kingdom between two important medieval cities, Roskilde on Zealand and Lund in Scania, probably contributed to the expansion of trade within the walls of the city.

${ }^{11}$ The precise reason is unknown. But two factors probably played a key role. First, the Reformation likely served to lower demand, which instigated declining prices. Second, to compensate for lower prices larger landings were nessesary requiring larger vessels beyond the economic reach of Danish fishermen. As a result, Dutch fishermen (living in the major economic power at the time) essentially took over (Holm, 1998).

${ }^{12}$ Another important source of revenue from the Sound, starting in the 15th century, was the so-called "Sound dues". This source of revenue dries out around 1660 due to Denmark's loss of Scania to Sweden. Hence, both sources of income, fish trade and sound dues, decline around the same time. The relative royal revenues from the two components in difficult to assess. The best guess is probably records from the reign of King Hans (1481-1531), which suggest that revenue from the fish market and the sound dues constituted about $25 \%$ of total royal revenues, of which $2 / 3$ were sound dues (Hybel and Poulsen, 2007, Table 13). While the direct revenue from the fish market can be corroborated by other sources, the sound dues may be exaggerated. Moreover, a fraction of toll revenue would naturally derive from merchants involved directly or indirectly in the fish trade.
} 
It is worth stressing that the importance of fish trade, during the late Medieval period, is not unique to Copenhagen. In fact, a case can be made that international trade in fish was quite possibly the third largest trade flow in Europe, after textiles and grain (Holm, 1998). As observed by Hoffman (2005, p. 23-4)

In about the tenth century, records from several European regions show people catching fish for sale to nearby consumers... Local markets for fish were an integral, indeed often precocious, element in the early rise of an exchange sector, i.e. the start of what historians call the 'Commercial Revolution of the Middle Ages' which became fully visible as it grew during the eleventh and twelfth centuries. Artisan fishers first appeared at inland and coastal sites with access to consuming centres, especially emerging towns such as Ravenna, Gdansk, Dieppe, Lincoln or Worms, and such people 'who make their living from fishing' spread and multiplied from there.

The rising importance of fish in international trade is further supported by archeological evidence, which shows that fishbones from non-local marine fish rises in importance in the diet in Europe during the late Medieval period (e.g., Barret et al., 2004a,b). Hence, during the early phases of the second millenium C.E international trade in fish arguably helped develop markets across Europe, which served to draw in other forms of trade as well. In its own way, this may have helped support an emerging Commercial Revolution.

\subsubsection{The New World}

The influence from marine resources was not limited to the Old World. For example, the bounty of the sea had a significant role to play in the context of the colonialization and development of parts of North America. In 1602 Bartholomew Gosnold, searching for a passage to Asia, comes across a place he chooses to call "Cape Cod". Roughly a decade later, in 1614, Captain John Smith arrives and eventually publishes a map of the region, in 1616, which allow others to follow. Moreover, Smith apparently becomes a wealthy man by selling the proceeds from the trip, which involves 7,000 green cod and 40,000 stockfish. Curiously, John Smith thereby seems to have served as an impetus for the establishment of the Plymouth colony at Cape Cod, in 1620. As Kurlansky (1997, p. 67) observes: ${ }^{13}$

... studying the famous captain's map, the Pilgrims decided to ask England for a land grant to North Viginia, where there was this Cape Cod. Bradford wrote: "The major part inclined to go to Plymouth, chiefly for the hope of present profit to be made by the fish that was found in that country". When the British court asked them what profitable activity they could engage in with the land grant, they said fishing.

\footnotetext{
${ }^{13}$ The quote refers implicitly to chronicles made by the governor of Massachusetts, William Bradford.
} 
The apparent "allure" of rich fishing grounds should be appreciated in light of the international market for fish in Europe, which, as discussed above, had been around for a long time by the 17th century. The Pilgrims almost surely would have been keenly aware of these development as they prior to their "exodus" were living in the Netherlands, perhaps the leading maritime power at the time.

There is nothing much to suggest, however, that the "Pilgrim Farthers" were particularly successful in the fishing enterprise. But the New England region eventually becomes deeply influenced by fishing. Indeed, as observed by Adam Smith (1776, Chapter 7, part II: Causes of the Prosperity of New Colonies):

To increase the shipping and naval power of Great Britain by the extension of the fisheries of our colonies, is an object which the legislature seems to have had almost constantly in view. Those fisheries, upon this account, have had all the encouragement which freedom can give them, and they have flourished accordingly. The New England fishery, in particular, was, before the late disturbances, one of the most important, perhaps, in the world. ... Fish is one of the principal articles with which the North Americans trade to Spain, Portugal, and the Mediterranean.

Hence, marine resources clearly contributed to the development of New England, through foreign trade. Kurlansky (1997, p. 74) puts it succinctly:

New England was perfectly positioned for trade. In cod it had a product that Europe and European colonies wanted, and because of cod it had a population with spending power that was hungry for European products. This was what built Boston.

Hence, via the evolution of international markets and cities, a rich bounty of the sea may therefore have had significant effects on long-term development, in some regions of the world. This impact could be very persistent, since urban development appears to be charactarized by a considerable degree of path-dependence (e.g., Bleakley and Lin, 2012).

\subsection{Formal and Informal Institutions}

If marine resources have served to influence the structure of the economy, as the historical evidence suggests, one might suspect that the bounty of the sea also could have left an imprint on the outlook of the people; i.e., in terms of their values, and perhaps also with respect to preferred institutions. If so, marine opportunities would impact on economic activity through non-geographic fundamental determinants of productivity (Acemoglu, 2008, Ch. 4).

The field of maritime anthropology has long drawn attention to the fact that fishermen and their families across the globe share certain personality traits and values. ${ }^{14}$ As a result, this reserach program has developed

\footnotetext{
${ }^{14}$ See Acheson (1981) and McGoodwin (1990) for overviews of the early literature.
} 
the notion of a distinct "fisherman culture". The underlying idea is that fishermen psychoculturally adapt to their occupation, which is similar in spirit to the idea that agricultural activities have influenced values and beliefs (e.g., Alesina et al., 2013; Bentzen et al., 2015; Galor and Özak, 2014; Talhelm et al., 2014). There are three particularly oft-cited charactaristics of a fishermen culture: Risk tolerance, individualism and a comparatively high degree of gender equality.

The idea that fishermen tend to be more risk tolerant than agriculturalists is based on the simple observation that (marine) fishing is a risky activity since changing weather and sea conditions jeopardizes personal safty, as well as physical capital and catch. Simply put, all seagoing fishermen risk having their vessel sink, or having themselves or their catch swept overboard. These types of risks are arguably not found to the same extent in agrarian occupations. This view is supported by experimental evidence. For example, in a study of fishing communities around Lake Victoria, Eggert and Lokina (2007) documents how fishermen tend to be risk seekers if fishing constitute the main source of household income. In fact, it would appear that seamen more generally tend to be charactarized by more risky behavior (Rafnsson and Gunnarsdottir, 1993). Hence, if a rich bounty of the sea eventually led to other ocean-going occupations, beyond the fisheries, this might have helped further a more risk tolerant culture. ${ }^{15}$

Another central theme of the maritime anthropological literature is that fishermen psychologically adapt to the risky work environment by valuing independence and self-reliance, which are core aspects of an individualistic culture. At sea fishermen are forced to make rapid decisions, which have immediate consequences for the success of fishing and the well-being of one-self and other crew members. Independence arguably help fishermen cope with this requirement. Early ethnographic evidence is widespread and found in fishing communities from very different parts of the world such as the Caribbean Islands, Malaysia, Thailand, Brazil, Panama, and Northeastern USA (Poggie, 1980). Based on participant observation and survey data, the studies document how fishermen percieve themselves as independent and highlight the ability to be independent as an attractive component of their profession. Later studies in maritime anthropology have confirmed the early findings, using alternative methodologies. An example is McConney (1997), who examines different groups involved in the small-scale pelagic fishery in Barbados. Based on surveys, social network analysis, and participant observation, he provides evidence that fishermen are engaged in more individualistic social networks than for instance fish product vendors. He argues that this is a social strategy to cope with uncertainties associated with fishing.

The third charactaristic of a fishermen culture concerns gender roles. A majority of fishermen are male, and with men being absent on fishing trips, women tend to assume a more independent and powerful role in the household and society (McGoodwin, 1990). For instance, women often contribute to the marketing and

\footnotetext{
${ }^{15}$ As Rafnsson and Gunnarsdottir (1993, p. 1379) conclude: "The association between fatal accidents other than at sea and length of employment as seamen indicates that seamen are modified by their occupation towards hazardous behaviour or a risky lifestyle."
} 
distribution of fish. Recently, BenYishay et al. (2014) has provided empirical evidence that ethnic groups relying on fishing are more likely to be characterized by matrilineal inheritance.

From previous work in political science and economics one may deduce another pathway of influence from marine resource: via institutions. As discussed in the last section marine ressources may well have helped propel international trade and city growth, thereby supporting a growing class of merchants and traders. If merchants and traders have keen interests in institutions supporting property rights, as argued by Acemoglu et al. (2005), creating and maintaining institutions protective of property rights may have been relatively easier in regions abundant in marine resources. Another possibility is that a relatively low degree of transparency of the exact return on marine fishing, from the point of view of a ruling elite, might support property rights institutions. Maysha et al. (2013) propose a theory of the scale of the state, and in terms of property rights institutions, according to which low transparency in productive outcomes tend to generate "better" institutional outcomes. Quite possibly, the outcome of marine fishing is less transparent than most forms of agricultural production. An impact on institutions could also emerge in a more indirect way. If marine ressource have served to advance individualistic values, as suggested by the anthropological literature, this could also serve to advance the formation of democratic institutions (Gorodnichenko and Roland, 2013).

More broadly, if a rich Bounty of the Sea has stimulated economic development, property rights supporting institutions (democracy) may emerge as a direct result thereof in keeping with Lipset's (1959) modernization hypothesis. A virtuous circle of improving institutions and economic growth may thus be envisioned. ${ }^{16}$ This process may also include cultural change as suggested by Inglehart and Welzel (2005) in their alternative view of the consequences of modernization. They argue that the link from economic growth to democratic institutions is indirect and mediated by changing cultural and social values, which are deeply linked with the development process. Individualism and risk tolerance is for instance predicted to rise as the external constraints on human choice become weaker.

If indeed a rich bounty of the sea eventually has helped shape values and institutions, an impact on economic development is to be anticipated. In particular, if marine resources has served to promote a relatively individualistic culture, either directly or indirectly, a positive impact on economic development would be the reduced form prediction, as the level of individualism arguably is conducive to growth (Gorodnichenko and Roland, 2011). Similarly, if marine resources has supported property rights supporting institutions this too would support a positive impact on long-run economic development (e.g., Acemoglu et al., 2001; 2002; Acemoglu et al., 2014). Whether these predictions are borne out in the data is explored in the remaining.

${ }^{16}$ The Lipset-hypothesis remains controversial however; see e.g. Acemoglu et al. (2008) vs. Barro (forthcoming). 


\section{The Bounty of the Sea Index}

Assessing how reliant societies have been on the exploitation of marine resources is associated with several obstacles. Obtaining global historical data on marine fish landings and fishing activities is difficult - and even if such data were easy to collect, its usefulness for a study like this would be limited by the fact that actual landings of fish would likely be endogenous to regional productivity levels. We therefore construct the Bounty of the Sea (BoS) Index as a measure of the potential abundance of exploitable marine fish resources in the oceans. The informational content of our index rests, then, on the assumption that societies adjacent to oceans richer in marine fish resources were more likely to engage in fishing activities. We test this assumption in a variety of ways in the next section.

Underlying the construction of the BoS index is the well established marine biological fact that differences in oceanographic and climatic conditions are key drivers of the abundance as well as composition of marine resources in the global oceans, thus shaping the productivity of marine fisheries (Cheung et al., 2010). While all marine resources are limited in abundance by the requirement for nutrition and space, individual species exhibit distinctive preference profiles with relevant ocean conditions. The most favourable combination of such conditions tend to coincide with the midpoint of a species' actual geographical range (Jennings et al., 2009). On top of that, migratory species migrate along their calculated areas of habitat suitability (Cheung et al., 2010).

Following these insights, we make use of a database constructed by AquaMaps that predicts the global habitat suitability of most marine fish species by matching knowledge of their preference profiles with local environmental conditions. Specifically, based on the environmental parameters sea depth, seawater temperature, salinity, primary production, and ice cover, the survival probability of individual species is calculated at a 0.5 by 0.5 decimal degree grid level. Accordingly, the data speaks to whether a particular species of fish could be observed in a particular location, not to whether the species in actual fact is observed in that location. ${ }^{17}$ With the AquaMaps database in hand, the BoS index is calculated as the composite habitat suitability of marine fish species that are identified as carrying substantial weight in the global fisheries.

For the baseline BoS index we selected 15 species, which together made up a majority of the global marine fish landings in the 1950s according to FAO. ${ }^{18}$ Naturally, the more abundant, accessible and (nutritionally) valuable a species is, the more likely it is to be associated with large fishery catches. ${ }^{19}$ By focusing on such species, the BoS index will not only reflect the general productivity level of the oceans, but also ocean conditions that support species that share the characteristics of being particularly exploitable. Furthermore,

\footnotetext{
${ }^{17}$ In the Supplementary Appendix we provide further details on the raw data from AquaMaps.

${ }^{18}$ A list of these species are reported in Table A1 in the Supplementary Appendix. The 15 species accounted for $52 \%$ of the global marine fish catch according to the the FAO FIGIS database, which reports the catch volume (tons) of fish landed by individual countries, by species or higher taxonomic levels, for the period 1950-2012.

${ }^{19}$ See the discussion and evidence by Sethi et al. (2010), Branch et al. (2010), and Pauly et al. (2013).
} 
limiting our attention to important species of the 1950s, which is the earliest period for which global landings statistics at the species level exist, is important. Since the 1970s modern fishing technology has developed rapidly (McGoodwin, 1990) and a targeting of smaller species of lower trophic levels has been documented (Pauly et al., 1998). By focusing on an earlier period we hope to ensure that the BoS index is a sensible proxy of potential marine resource abundance historically. Several arguments can be made in favor of the desired historical usefulness of the index.

First, a majority of the species included in the baseline BoS Index did carry importance before 1950, as evidenced by archeological studies of fish bones. Codfish (cod, haddock, and pollack among others) were for instance among the most commonly caught marine fish species during the Stone Age in Denmark (Enghoff et al. 2007). In England the catch of Atlantic cod and herring expanded greatly around the year 1000 C.E. (Barrett et al. 2004a, Barrett et al. 2008). Before this period and dating back to $3500 \mathrm{BCE}$, codfish have consistently made up the majority of bone assemblages found in Northern Scotland (Barrett et al. 1999). On other continents, remains of the Peruvian anchovy have been detected in the coastal parts of the Incan Empire for the years 1100-1450 C.E. (Marcus 1987) and in ancient settlements on the Peruvian coast dating back to 10,000 BP (Keefer et al. 1998). Second, it seems that pressure caused by human fishing activity on local availability of marine resources does not cause long term differences in the global pattern of oceanic productivity. As Huston and Wolverton (2009) explain, when some species tend to be depleted in a region: "they are typically replaced by a fishery based on a lower trophic level that is often more productive than the original fishery, consistent with ecological theories of trophic dynamics" (p. 344). In other words, the relatively more productive oceans today are likely to have been the relatively more productive ones in the past as well, even if the nature of the exact target species changed over time; it is therefore plausible that areas judged as most productive based on relatively contemporary landings, were also the most productive areas in the past.

Our baseline BoS index is calculated as an unweighted average of the habitat suitability of the 15 species identified as being most important to the global fisheries in the 1950s. The index is aggregated to country level using each nations exclusive economic zone (EEZ). ${ }^{20}$ Landlocked countries are assigned a BoS value of zero. Figure 1 illustrates our baseline BoS index for the world's oceans and the country specific EEZ.

Several observations are worth making in light of the revealed worldwide distribution of exploitable marine fish. First, one observes a higher potential abundance along the coasts and in particular associated with the continental shelf. ${ }^{21}$ This is in accordance with the marine biological literature as shelf waters are characterized by a high content of nutrients that are derived from the continental landmasses and released by

\footnotetext{
${ }^{20}$ The EEZs are prescribed areas by the United Nations and represent territories over which coastal countries have exclusive fishing rights and jurisdiction over natural resources, and that stretch up to 200 nautical miles from each individual country's coastline. A shapefile for exclusive economic zones is found at http://www.marineregions.org/downloads.php

${ }^{21}$ The continental shelves are underwater landmasses that extend from the continents and ends with a steep slope towards the deep ocean floor. The shelf is characterized by being very flat and located at depths no larger than 150 meters.
} 

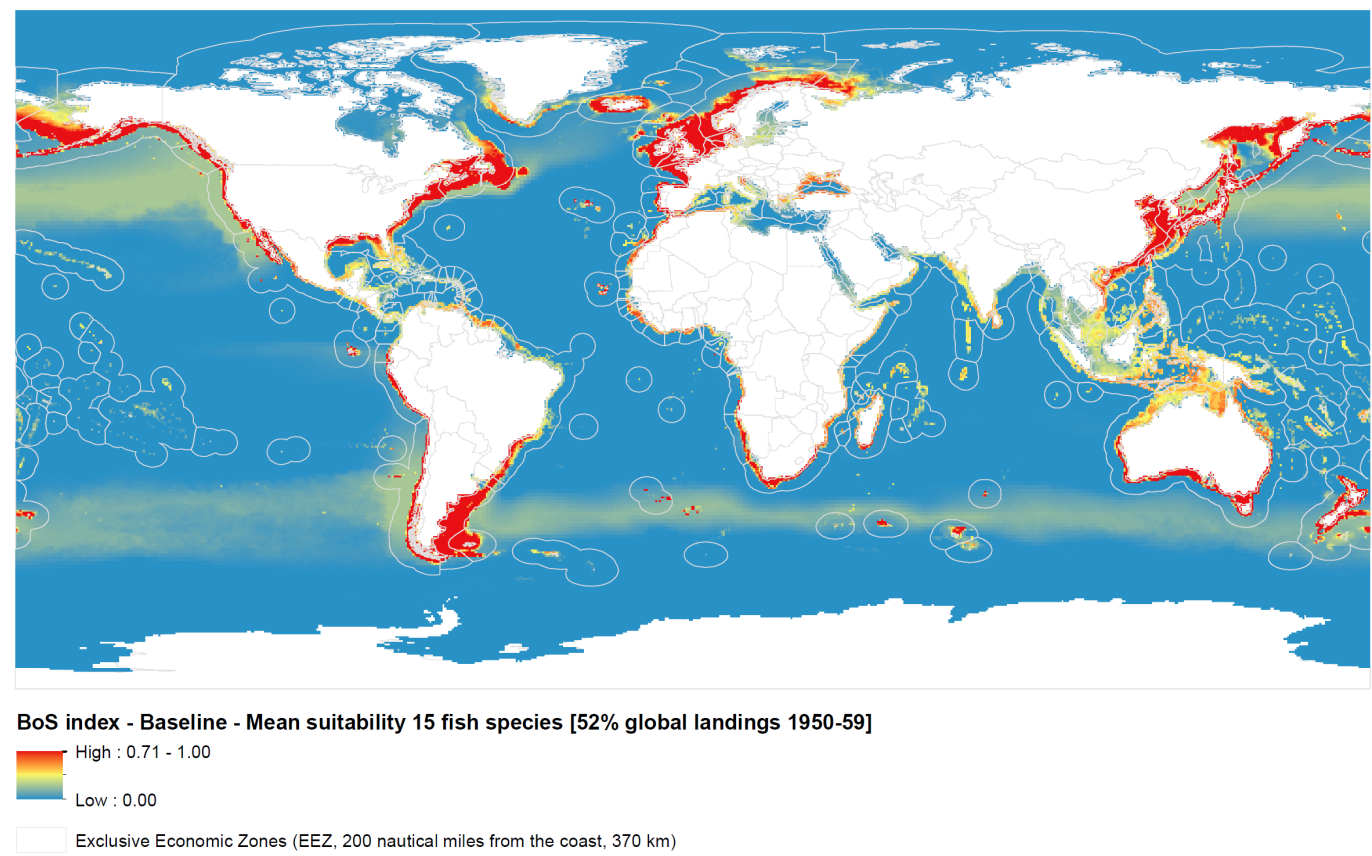

Figure 1: The Bounty of the Sea index, baseline measure. Notes: The index captures the (unweighted) average survival probability for 15 major fish species.

coastal upwelling effects. ${ }^{22}$ Combined with the accessibility to humans of its shallow waters and proximity to land, the continental shelf is the most exploited and productive ocean area in terms of fishing globally (Watson et al., 2004, King, 2013). The width of the shelf varies considerably from being very narrow around the African continent to stretching the entire North Sea in Europe. Second, there appears to be a latitude gradient in the BoS index: places further away from the equator are associated with having access to relatively richer maritime envionments. This resonates with marine biological insights on the impact of temperature. Warmer waters tend to be less productive due to wider vertical temperature differences, which prevents nutritious bottom layers from mixing with surface layers (Valavanis et al., 2004). Moreover, it has been observed that temperate and colder waters generally host larger aggregations of single species, which naturally are more easily exploitable (King, 2013). ${ }^{23}$ This corresponds with the fact that species diversity declines with increasing latitude and distance from southeast Asia and the Caribbean (Tittensor et al., 2010). ${ }^{24}$ Finally, regional hotspots of marine productivity identified by the literature are reflected in the BoS index. Such hotspots are the outcome of strong upwelling effects, nutrient terrestrial runoff, and the

\footnotetext{
22 "Upwelling" is an oceanographic phenomenon that involves wind or current driven motion of dense, cooler, and usually nutrient-rich water towards the ocean surface, replacing the warmer, usually nutrient depleted surface water.

${ }^{23}$ Research has even documented how marine fish in higher latitudes are more mobile as they respond to seasonal changes in temperature, making them more likely to form tight shoals and thereby become easier targets for fisheries (Floeter et al., 2004).

${ }^{24}$ South East Asia has especially been identified as a centre of evolution and specification of marine resources as it is home to some of the oldest marine ecosystems of the world (Ursin, 1984).
} 
redistribution of nutrients by ocean currents. ${ }^{25}$ These processes also produce regional spots of relatively low productivity like the Mediterranean Sea, where nutrient depleted Atlantic surface waters flow in through the Strait of Gibraltar in exchange for deep and more nutrious Mediterranean waters (Estrada, 1996). Overall, there appears to be substantial variation in the BoS index across and within continents and these patterns are in accordance with key marine biological principles.

Naturally, concerns may be raised in the context of our baseline measure. First, one may worry that our particular selection of species suffers from selection bias: if the most technologically sophisticated nations in the world (in the 1950s) also were the most productive in fishing, the species found in these regions might well end up dominating global landings and therefore our BoS index. ${ }^{26}$ To address this concern, we identify the most caught fish in every country around the world in the 1950s, thus avoiding a potential "technology bias" in the selection of species. The downside of this measure is, of course, that this alternative index may involve species that only to a very limited extent are exploitable, as reflected in a potentially very low number of global landings. Consequently, this measure may be somewhat noisy, making the regression results sensitive to measurement error. This proceedure leads to an alternative list of 41 different species (cf. Table A1 in the Supplementary Appendix). Hence, our first alternative BoS index is the unweighted average habitat suitability index of these 41 species.

Second, one may worry that the size of the EEZ is endogenous (just like country borders usually are). To be sure, the extent of the EEZ is at times the source of conflict - the "cod-wars" between Iceland and England during the 1960s being a case in point. ${ }^{27}$ To address this concern our second alternative BoS index aggregates the average survival probability of the top 15 fish during the 1950 s using a $10 \mathrm{~km}$ buffer zone around countries' coastlines. This reduction in "relevant fishing area" also works to diminish the concern that, in historical times, the exploitation of marine resources occured somewhat closer to the coast than what is implied by the current EEZ area.

Finally, one may wonder if "all fish are equally important"? That is, perhaps a superiour index would weigh the individual survival probabilities in some way? To adress this issue we also construct nutritionweighted BoS indices. The nutritional value of commercially important fish species are reported by FAO (1989) in a comparable manner. These values are used to weigh the baseline Bounty of the Sea index according to calorie content, fat content, and protein content of each species, respectively. ${ }^{28}$

\footnotetext{
${ }^{25}$ Major upwelling area are associated with the Canary (off Northwest Africa), Benguela (off Sourthern Africa), California (off California and Oregon), and Humboldt (off Peru and Chile) currents (King, 2013). Nutrient terrestrial runoff is particularly associated with glaciated, high-latitude soils and, globally, the outflow of major rivers including the Ob, Mackenzie, Mississippi, Amazon, Parana, Congo, Tigris and Euphrates, Indus, Ganges, Irrawaddy, Yangtze, and Huang (Huston and Wolverton, 2009).

${ }^{26}$ Note that similar concerns might be raised in the context of the selection of key crops for indices involving land suitability, see Nunn (2014, p. 370).

${ }^{27}$ See Kurlansky (1997, Ch. 10) for a vivid account.

${ }^{28}$ Of the 15 marine fish species in the original Bounty of the Sea Index only 12 are associated with nutritional values in FAO (1989). The species not included are the Gulf menhaden, Atlantic menhaden, and Alaska pollock.
} 
In sum, in addition to our baseline measure we construct five alternatives, which differ in terms of: (i) the selection of relevant species; (ii) how we aggregate average survival probabilities to the country level, and, (iii) the weightning scheme involved in calculating the average survival probability (fats, protein, calories, respectively). Importantly, each of these indicies involve changes in assumptions in one dimension at a time, compared with the baseline index. By comparing regression results when alternative indicies are invoked, we are thereby able to gauge which of our baseline assumptions (if any) may seem critical.

\section{Validating the BoS Index}

The BoS index is by construction developed to capture the potential for marine exploitation. A natural question to ask is whether this potential seems to have been borne out. This is the question we ask in the present section.

We begin by exploring the predictive power of the BoS index vis-á-vis actual landings during the 20th century. Subsequently, we explore whether the BoS index predicts the allocation of labor during the 19th century, in coastal regions around the North Atlantic, and if the index predicts the contribution from fishing to subsistence in traditional societies recorded in the Ethnographic Atlas.

\subsection{The Harvesting of Marine Ressources}

Comparable data on total marine fish landings across countries can be obtained back to the year 1900. For the period from 1950 the source is the FAOs FIGIS database, and for the period before 1950 two historical collections are available: ICES Historical Landings 1903-1949 (ICES dataset) for 17 European countries and Mitchell's International Historical Statistics (IHS dataset) for 48 countries across the globe. ${ }^{29}$ We use these data sets to assess how well the Bounty of the Sea Index predict actual landings across the $20^{\text {th }}$ century.

Table 1 reports the results of regressing the log of yearly marine fish landings in tons on the Bounty of the Sea Index, controlling for the log of the sea area (EEZ or buffer area). In columns 1 and 2 the outcome variables are historical landings during the period prior to the $1950 \mathrm{~s}^{30}$

Table 1

As seen the BoS index indeed predicts yearly landings during the period from 1900-1940; along with the EEZ area the BoS index accounts for in between $25 \%$ and $40 \%$ of the variation. This is reassuring in that the species included in our index were not selected on the basis of actual landings during this period. Naturally, the sample sizes are of somewhat limited size.

\footnotetext{
${ }^{29}$ See the appendix for a description of these data collections.

${ }^{30}$ We disregard the 1940s in order to avoid how the Second World War hampered landings in an assymmetric manner.
} 
Column 3 confirms that the BoS index exhibits a positive correlation with landings during the 1950s, as expected; this remains the case when we explore within continent variation (column 5). Along with sea area, the BoS index accounts for about $1 / 3$ of the variation in the global data set on actual landings.

As a second out-of-sample check, we explore whether the BoS index remains significantly correlated with observed landings after the 1950s; see column 4 and 6 . Once again the answer is in the affirmative, and the $R^{2}$ even increases to about 0.5 . As can be seen from Table A1 the most important species for world wide fisheries diversified considerably after the 1950s. Hence, the significant explantory power of the BoS index during this period both supports the prior that data on the potential abundance of marine resources carry predicting power of actual marine fish landings, and the prior that the index most likely proxies the riches of local oceans more broadly than what pertains to the exact species selected for the index.

\subsection{Labor force allocation}

Besides predicting marine fish landings across countries throughout the 20th century, the Bounty of the Sea Index can be compared to data going further back in time reflecting the allocation of societies' labor resources to activities related to the harvest of marine fish. Using historical survey data from the North Atlantic Population Project ${ }^{31}$ and based on the reported occupation codes, we compute the number of people engaged in fishing across regions within six North Atlantic countries (Norway, Sweden, Iceland, United Kingdom, United States, and Canada), for different years within the period 1801-1910. ${ }^{32}$ Disregarding landlocked regions, we aggregate the Bounty of the Sea Index within a $100 \mathrm{~km}$ buffer zone from each region, and proceed to test how well the Bounty of the Sea index explains variation in the employment share of fishermen across 80 regions within these 6 countries.

Conditioning on the buffer area of the sea, survey year fixed effects, country fixed effects, and total population or total employment in each regions, the results in Table 2 document that the BoS index is positively correlated with the number of fishermen across regions in the six North Atlantic countries throughout the 19th century, and during the beginning of the 20th century.

Table 2

\subsection{Food supply in traditional ethnic societies}

In the checks above we have focused on whether the BoS index appears to carry explanatory power vis-á-vis the actual bounty of the sea, measured by observed landings, and if the BoS index seems to correlate in

\footnotetext{
${ }^{31}$ Collected by the Minnesota Population Center, this data contains census microdata from Canada, Great Britain, Germany, Iceland, Norway, Sweden, and the United States from 1801 to 1910. Germany, which is actually just the region MecklenburgSchwerin, is left out in the present analysis.

${ }^{32}$ The subnational regions in the data set compare to the present day first-level divisions of these countries.
} 
the expected way with what people do; i.e., whether areas adjacent to rich maritime waters also seem to be charactarized by more people preoccupied with exploiting them. Another issue is whether the BoS index also predicts the extent to which societes have relied on fishing for subsistence.

To explore this issue we turn to data on traditional societies recorded in the Ethnographic Atlas (EA) and the Standard Cross Cultural Sample (SCCS), respectively, and identify those located within $200 \mathrm{~km}$ from the coast. ${ }^{33}$ We find the appropriate value of the Bounty of the Sea Index for all traditional societies with centroids located within $200 \mathrm{~km}$ from the coast, by creating a $100 \mathrm{~km}$ buffer from the point on the coastline which is nearest to the centroid of each respective ethnic society, and computing the average BoS within that buffer. With this procedure we obtain data for 100 traditional societies in the SCCS, and 546 in the EA, which we can use to test whether the potential abundance of marine resources is correlated with the extent to which traditional and ethnic societies across the globe rely on fishing (and thus more broadly hunting and gathering) relative to agriculture. This is feasible as both data sets provide information on the contribution of gathering, hunting, fishing, animal husbandry, and agriculture to the total food supply. ${ }^{34}$

Table 3

Columns 1-5 of Table 3 show a clear pattern: controlling for the area of the BoS buffer, distance from the centroid of each society to the coastline, and the year in which data for each respective society was collected (which ranges from $800 \mathrm{BCE}$ to 1960 C.E.), the BoS index is negatively associated with the contribution of animal husbandry and agriculture to the food supply, but positively correlated with the contribution from hunting and gathering, and, importantly, fishing.

For the group of traditional societies included in the Ethnographic Atlas, which involves a larger selection of societies, we find the same pattern (cf Column 6-10): the potential abundance of marine resources is positively correlated with hunting, gathering and fishing, and negatively correlated with animal husbandry and agriculture.

Overall, these results suggest that in areas charactarized by a greater BoS index it would be more likely to see societies that relied (to a significant extent, albeit not nessesarily exclusively) on the exploitation of marine ressources for subsistence.

\footnotetext{
${ }^{33}$ The geographical coordinates of the ethnic group centroids are reported in the SCCS. From this point we calculate the distance to the nearest coast and disregard those with a distance of more than $200 \mathrm{~km}$. The use of $200 \mathrm{~km}$ as the radius within which the ethnic groups have been likely to move around follows Alesina et al. (2013).

${ }^{34}$ Specifically, the indices range from $0-9$, where 0 represents $0-5 \%$ dependence, 1 represents $6-15 \%, 2$ represents $16-25 \%$, so on up to 8 , which represents $76-85 \%$ dependence, and 9 , which represents $86-100 \%$ dependence.
} 


\section{The Bounty of the Sea and Economic Development}

\section{$5.1 \quad$ Empirical Strategy}

In the remainder of this study we explore the links between the BoS index and various outcomes at the country level $\left(y_{i}\right)$ : population density, GDP per capita and a range of measures pertaining to personality traits, cultural values and institutional outcomes, respectively.

Formally, the regression model that we take to the data can be written

$$
y_{i}=\beta_{1} \mathrm{BoS}_{i}+\beta_{2} \mathrm{AG}_{i}+\mathbf{X}_{i}^{\prime} \gamma+\varepsilon_{i}
$$

where $y_{i}$ is the outcome of interest, "AG" is a measure of agricultural land productivity, whereas the vector $\mathbf{X}_{i}$ comprises a set of control variables and a constant term.

In the main body of the analysis we restrict $\mathbf{X}_{i}$ to comprise a relatively limited set of covariates; in the appendix we extend it considerably whenever deemed relevant, as explained below. Accordingly, our baseline controls include, in addition to land productivity and the BoS index: the timing of the Neolithic revolution; sea area and land area; a full set of continental fixed effects; the distance to the equator; a dummy variable which takes on the value one if the country is landlocked, and finally, the fraction of land area within 100 $\mathrm{km}$ of the ocean or navigatable river.

Land productivity is included in all specifications, alongside the BoS index since we are interested in comparing the long-run impact from potentially relying on a maritime subsistence strategy rather than (solely) agriculture; i.e., the relative size and sign of $\beta_{1}$ and $\beta_{2}$. Similarly, we control for both sea area and land area in all cases, since we are interested in the importance of greater "quality" of the environment, for its size given. The timing of the Neolithic Revolution is added since it allows us to assess the importance of sea and land productivity, conditional on the time at which agriculture entered the scene. Distance to the equator (absolute latitude) is in the control set to capture in a parsimonious way climatic conditions that may (through a variety of mechanisms) have influenced productivity in the past, as well as exert an impact on outcomes today. Moreover, since there appears to be something of a latitude gradient in our baseline BoS index, the omission of absolute latitude would increase the risk that our results become tainted by omitted variable bias. In light of the discernible continental-wide differences in marine productivity, continental fixed effects are included to capture unobserved heterogeneity. Finally, in order to control for the potential access to the sea we include the percentage of land within $100 \mathrm{~km}$ of coasts and waterways and a dummy variable which takes on the value of 1 if the country is landlocked. Data description, summary statistics, and sources for our control variables are found in the Supplementary Appendix. 


\subsection{Pre-Industrial Development}

In Table 4 we report the results from estimating equation (1) when log population density in 1500 C.E. is the outcome of interest. The regression parameters are standardized throughout. Accordingly, the individual regression coefficient speaks to the change in the left hand side variable, measured in standard deviations, that results from a change in the right hand side variable by one standard deviation. This facilitates a simple comparison of the economic significance of the individual controls. Statistical significance are reported in parenthesis (p-values).

Table 4

In the first five columns we add the auxiliary controls sequentially, and then collectively (column 5). The BoS index is in all settings significant at the five percent level of significance, or better, and carries a positive point estimate. The same is true both for our measure of soil suitability for agriculture, and for the timing of the Neolithic. Hence, these results suggest that, for given land productivity and length of agrarian history, countries that could rely on a relatively richer Bounty of the Sea were more densely settled in 1500 C.E. ${ }^{35}$ Economically, the influence from the timing of the Neolithic is greater than both that of the BoS index and the agricultural counterpart. Conditional on the timing of the Neolithic, the impact from soil conditions is greater than that of the BoS, though the point estimates are of similar order of magnitude.

In column 6 we restrict the sample by excluding all landlocked countries. Naturally, being landlocked may have hampered development in its own right, for which reason it is of interest to inquire whether the BoS index contains explanatory power only between countries that have access to the ocean. Interestingly, the point estimate for the BoS index does not seem to be much affected, statistically and economically. ${ }^{36}$

In columns 7-10 we employ our alternative BoS indices, with and without landlocked nations being present in the sample. The results are very similar. This is reassuring in that it indicates that our BoS index probably is not haunted by selection bias in any substantial way via of the selection of species, nor by a potential endogeneity bias due to the geographical unit we aggregate to.

In the Supplementary Appendix we explore the robustness of these results in several ways. First, we examine if the results hold up if we solely focus on Europe and Asia, respectively. This check is motivated by the potential concern that the quality of the data on population density in 1500 C.E. may be lower outside these areas. Reassuringly, however, the size and significance of the BoS indices is very similar, albeit more

\footnotetext{
${ }^{35}$ It is interesting to note that the parameter estimate for absolute latitude is negative, suggesting greater economic development close to the equator in 1500 C.E.. This finding, suggestive or a climatic reveral in economic activity during the last half millennium, was first noticed in Ashraf and Galor (2011). See Dalgaard and Strulik (2014) for a possible explanation for the reversal, and discussion of alternative accounts.

${ }^{36}$ Throughout we include a control for being landlocked, which means we partial out the average difference in population density between coastal and non-coastal nations. When we exclude landlocked nations entirely we push matters a bit further by exploring the impact from the BoS index solely within coastal countries.
} 
economically significant (Tables A2-A3). ${ }^{37}$

Second, we study whether the results change if we rely on alternative BoS indices, which weigh individual species by their calorie content, their fat content, or their protein content. As documented in the Supplementary Appendix, the results are qualitatively and quantiatively similar to those reported above (Table A4).

Third, we examine the consequence of expanding the set of controls. In order to tie our own hands in the context of choosing specifications, we opted for those invoked by Ashraf and Galor (2013), who in turn build on Ashraf and Galor (2011), in the context of their study of pre-industrial development. That is, we simply add the BoS index (along with EEZ area) on top of their controls. As in Table 4, we also explore the consequences of omitting landlocked nations. The message from Table 4 carries over (see Table A5). ${ }^{38}$

Finally, we revert to our full specification and explore the influence from additional controls with direct bearing on marine conditions: an island dummy; average distance to coast or rivers; ocean biodiversity; the extent of tidal movements; the length of coastline and inland waterways to land area, respectively; the number of natural harbours relative to land area; and the percentage of the EEZ area which constitutes shelf area or is covered by estuaries, respectively. The BoS index remains significantly correlated with population density in 1500 C.E. despite the inclusion of these additional controls (See Table A6). ${ }^{39}$

\subsection{Contemporary Development}

Table 5 report the results from exchanging log population density in 1500 C.E. for log real GDP per capita in 2005 as the dependent variable. The specifications are, to begin, exactly the same as those invoked in Table 4 .

Table 5

The link between the BoS index and economic development is rather similar to that detected for the preindustrial period: a positive correlation emerges. In contrast, the sign of the correlation involving agricultural productivity has reversed, whereas the timing of the Neolithic no longer carries any significant explanatory power, statistically speaking.

\footnotetext{
${ }^{37}$ If the measurement error (in the dependent variable) is classical, one would only expect to see more imprecisely estimated parameters, not changes in point estimates (in contrast to measurement error on the independent variables). A priori, however, the measurement error could be non-classical. Our results can therefore be interpreted as indicating that the measurement error on population density in 1500 C.E. is classical in nature.

${ }^{38}$ To be clear, this approach is not to meant to suggest that we believe the specifications chosen by Ashraf and Galor (2011, 2013) necessarily are the "specifications to end all specifications", in the context of understanding population density in 1500 C.E. What this approach does demonstrate, however, is that our novel results are robust to the inclusion of the most commonly agreed upon determinants of pre-industrial development, at present.

${ }^{39}$ Estuaries are places where rivers run into the ocean and thus produces brackish water. The "Shelf" area constitutes relatively shallow waters (up to 200 meters in depth).
} 
In comparison with the pre-industrial setting, however, the estimates appear more sensitive to the chosen specification, and in some instances statistical significance is not attained. This finding raises the question of whether, in the 21st century, the local environment is really what matters to economic activity. Alternatively, the historical subsistence strategy may have affected the outlook of people, as discussed in Section 2, which perhaps is a more important source of influence on economic outcomes in the contemporary world. Yet the past 500 years has witnessed a considerable amount of international migration: In many countries around the world the current inhabitants have ancestry from elsewhere. As a result, a purely geographic variable may be a poor indicator of the environment within which the ancestors of the current population were found. This may explain why the BoS index seems less robustly correlated with economic outcomes today than what is the case for 1500 C.E..

Accordingly, Table 6 examines the consequences of ancestry adjusting the BoS index using using the population migration matrix constructed by Putterman and Weil (2010). The ancestry adjusted BoS index thus reflects the bounty of the sea of the countries from which the ancestors to the populations of today's countries have migrated during the past 500 years. ${ }^{40}$ In fact, in the model we ancestry adjust all variables that potentially speak to the historical subsistence strategy.

Table 6

The change in the nature of the results is noticable. In particular, the estimates become more stable, and increase in size. Moreover, whereas land productivity continues to enter with a negative sign after the migration adjustment, the ancestry adjusted timing of the Neolithic now also carries explanatory power and enters with a positive sign. Overall, these results suggest that the positive correlation detected in Table 5 largely reflect the influence from the historical legacy of the people of the country rather than the place itself.

To follow up, Table 7 reports the results from "horse-race" regressions where we simultanously control for the environment, and the environment of the ancestors of the current population.

\section{Table 7}

Intriguingly, the point estimate for the ancestrial BoS index maintains its statistical and economic significance whereas the purely geographical indicator ceases to be statistically significant. These results suggest that the importance of the BoS index today is not driven by local geographic conditions per se.

In the Supplementary Appendix we explore the robustness of these results in various ways. First, we study if the impact from the ancestry adjusted BoS index changes if we employ indices where individual species are weighted by their nutritional value. This is not the case (cf Table A7).

\footnotetext{
${ }^{40}$ Suppose the fraction $\pi_{i j}$ of the population in country $i$ decends from country $j$, the ancestor adjusted BoS index is calculated as $\sum_{j} \pi_{i j} B o S_{j}$, where $\sum_{j} \pi_{j}=1$.
} 
Second, we include controls for additional marine conditions, as in the previous section. The impact from the ancestral BoS index is unaffected by augmentating the control set this way (Table A8).

Third, we experiment with a different specification. Again, we chose to follow the specifications adopted in Ashraf and Galor (2013), in the context of their analysis of contemporary development, to limit our degrees of freedom, and to ensure that we capture the most of the commonly agreed upon (fundamental) determinants of development (tables A9-A10). Broadly speaking, the results are similar to the ones reported above, with an important corollary. In some specifications Ashraf and Galor (2013) include a measure of institutional quality: the Social Infrastructure index, due to Hall and Jones (1999). In these settings, the ancestry adjusted BoS index (with or without the simultaneous inclusion of the unadjusted BoS index) tends to loose significance. To the extent that differences in historical subsistence strategies have affected the outlook of people, this result need not be surprising, as a manifestation of such differences may be differences in the institutional infrastructure. We return to this issue below.

In way of concluding this section, Figure 2 depicts the partial correlation between the ancestry adjusted BoS index (baseline measure, as well as the indicator involving the top fish in each country), in both our full basic specification and when we employ the Ashraf and Galor (2013) specification omitting the social infrastructure variable. As is visually clear, the results do not seem fragile to any particular influential observation.
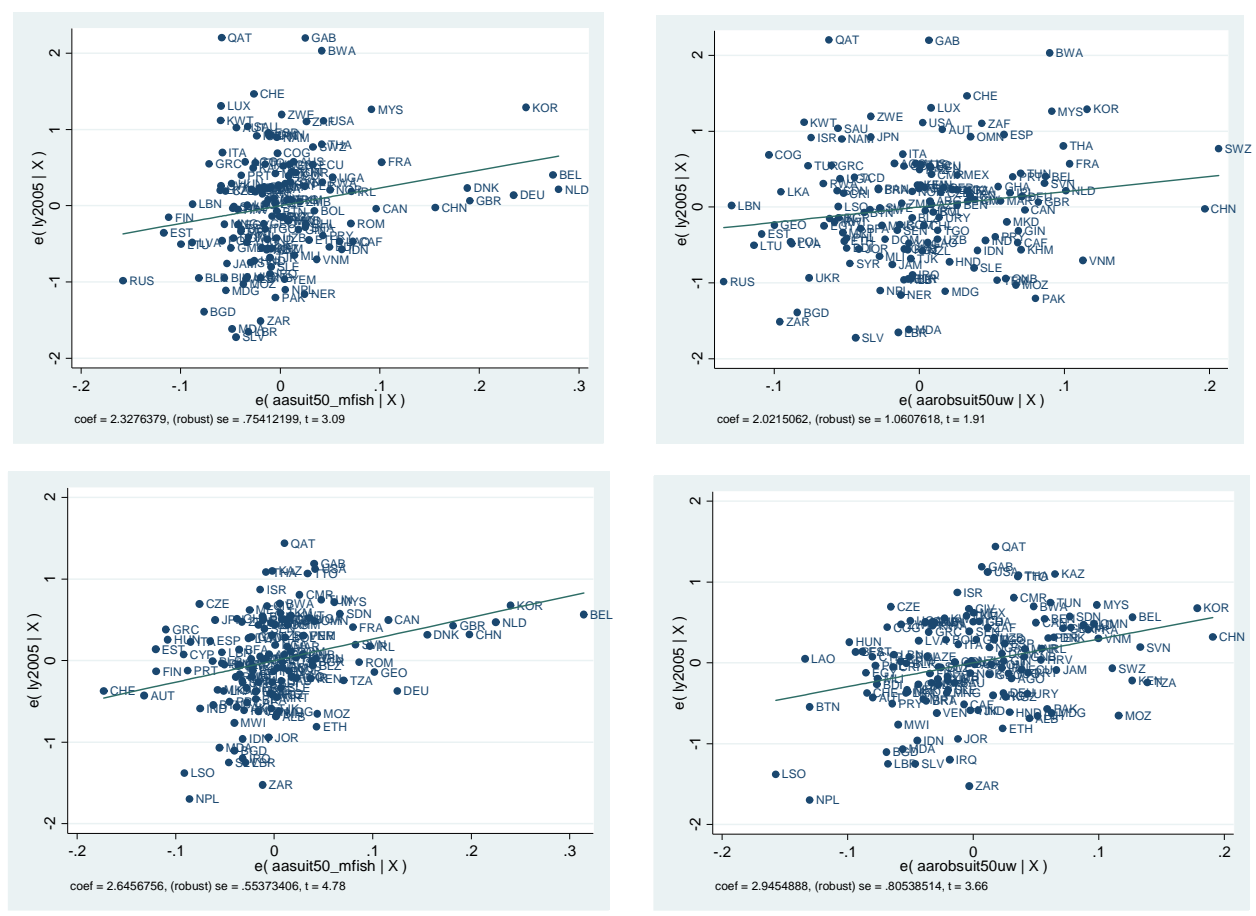
Figure 2. The partial correlation between ancestral BoS index and GDP per capita.

Notes: Top left hand side (LHS) picture depicts the baseline full specification and baseline measure whereas the top right hand side (RHS) figure shows the baseline full specification where the "top fish" BoS index is employed (Table 6, cls 5 \& 7). Lower LHS shows the result when we employ the baseline measure and controls from Ashraf and Galor (2013) short of Social infrastructure; the lower RHS figure shows the same though employing the "top fish" BoS index (cf Table A9, cls $8 \& 10)$.

\section{The Bounty of the Sea and Fundamental Determinants of Pros- perity}

The results above suggest that the contemporary influence from the Bounty of the Sea is most likely due to factors embodied in people. A meaningful check of this interpretation is to assess whether the bounty of the sea of current populations' ancestors explain cross-country differences in fundamental determinants of prosperity that are of a non-geographical nature. That is, does the ancestry adjusted BoS index correlate with measures of individuals' personality characteristics, societies' cultural values, and contemporary formal institutions?

As discussed in Section 2 there are reasons why one would expect to see a positive impact from the bounty of the sea on property rights supporting institutions on a priori grounds. To gauge whether such a link could be viable we therefore examine the conditional correlation between the BoS index and three commonly employed (countrywide) indicators of property rights: constraints on the executive; democracy and the rule of law index.

Similarly, work in anthropology suggests that the bounty of the sea could have left an imprint on cultural values. In order to inquire whether this is supported by cross country data, we employ the often used "cultural dimensions" developed by Geert Hofstede: Individualism; Power distance; Masculinity, Uncertainty Avoidance and Long-Term Orientation. Based on the discussion in Section 2 one might expect links to individualism (+), uncertainty avoidance (-) and masculinity (-).

Finally, recognizing that personality traits and culture likely are narrowly connected (Hofstede and McCrae, 2004), it seems worth exploring a possible link between the bounty of the sea and personality as well. In this context we rely on research done within psychology. The so-called Five Factor Model (FFM) proposes that the personality of individuals can be summarized by five personality dimensions, often referred to as the "Big Five": Openness to Experience, Concienciousness, Extraversion, Agreeableness and Neurotisim. In the analysis below we use data constructed by McCrae et al. (2005), which speaks to population level mean scores for each of these personality traits; the Supplementary Appendix provides details on the exact 
definition of each of these dimensions and offers a brief introduction to the "Big Five" literature. ${ }^{41}$

While the anthropological literature does not speak to the Big Five personality traits directly, it may still help form priors. In particular, the personality trait "Openness to Experience" seems to require a degree of risk tolerance on a priori grounds (McCrae, 1990). Consistent with this assessment, empirical work has found that entrepreneurs tend to score relatively highly on the "O-factor" (Zhao and Siebert, 2006). Indeed, studies that examine individuals' overall propensity to take on risk find a positive correlation with "Openness" (Nicholson et al., 2015). Furthermore, as individuals who score highly on the "O-factor" tend to be open to new ideas and values, a link to individualism might also be anticipated since deviations from the status quo are tolerated to a greater extent in individualistic cultures (e.g., Cukur et al., 2004). Accordingly, in the context of personality traits one would expect a positive correlation between the BoS index and "Openness to Experience".

\subsection{Institutions}

Table 8 report our results on institutional outcomes. We rely on three specifications: a stripped down version that only involve maritime and land productivity (in addition to continental fixed effects); our full baseline specification, and a specification which conditions for (log) GDP per capita.

Table 8

As can be seen, the BoS index is positively correlated with all three institutional measures, albeit most strongly with democracy and the Rule of law index. Seemingly, countries inhabited by populations with ancestry in regions featuring rich marine ressources tend to have institutions more favorable to private property rights. This correlation persists when we control for GDP per capita today, and we do not see a similar correlation with measures of agricultural legacy.

These results are broadly consistent with the prior that societies that are inhabited by people from regions rich on marine resources may have had an advantage in terms of developing (or adopting) property rights supporting institutions. Moreover, the results also indicate that the correlation is not driven by an impact on prosperity, as might be suggested by Lipset (1959) for example; controlling for income per capita does not render the BoS index insignificant. Beyond this, of course, the results provide little insight as to the exact mechanism behind the detected correlation. Exploring the link between marine resources and the evolution of institutions in depth seems like a worthwhile topic for future research.

\footnotetext{
${ }^{41}$ Briefly, the five factor model in psychology provides a hierarchical way of organizing personality traits. Each of the five factors (often referred to as "the Big Five") subsumes 30 underlying dimensions of personality (six for each of the Big Five), which in turn "aggregates" an even wider range of personality tendencies. See McCrae and John (1992) and Goldberg (1993) for an Introduction to the literature, and a description of its origins, which streches back to the 1930s.
} 


\subsection{Cultural Values}

Table 9 reports the results on cultural values.

Table 9

As can be seen, the only cultural variable that the ancestry adjusted BoS index appears to be significantly correlated with is "Individualism"; in all specifications a positive correlation emerges, as expected. The correlation becomes insignificant in the specification that controls for current income levels. We cannot therefore rule out that the association is driven by the modernization process as proposed by Inglehart and Welzel (2005). But as individualism has been found to spur economic growth (Gorodnichenko and Roland, 2011), obvious endogeneity issues arise, and the modernization hypothesis cannot be confirmed either. In contrast, ancestry adjusted land productivity consistently appears strongly and positively correlated with e.g. "Long Term Orientation". ${ }^{42}$ Hence, in the context of cultural values we also see a difference between the apparent ancestrial influence from a rich bounty of the sea and high agricultural productivity, respectively.

As discussed above one would also a priori anticipate a negative link to uncertainty avoidance. While this indeed is what we find, the estimate is usually insignificant (cf Table 9). ${ }^{43}$ Finally, there is no clear link to "Masculinity". ${ }^{44}$

\subsection{Personality Traits}

In Table 10 we report the results from examining the impact from the ancestry adjusted BoS index on personality traits.

Table 10

As can be seen, the ancestry adjusted BoS index only appears robustly correlated with the personality trait "Openness to Experience". In all specifications a positive correlation emerges, suggesting that populations with ancestry in regions with substantial maritime resources are on average characterized by a greater willingness and desire to engage with new ideas. Meanwhile, countries with populations descending from areas with high land productivity do not seem to be similarly inclined, over average.

\footnotetext{
${ }^{42}$ The link to long term orientation is consistent with the findings of Galor and Özak (2014).

${ }^{43}$ Some support in favor of the risk channel is found in that we do detect a significant positive link between ancestral land productivity and uncertainty avoidance (cf Table 9). If societies with high land productivity, for marine resources given, were characterized by less marine oriented occupations, this would be consistent with the contentions of the anthropological literature in terms of occupationally related risk attitudes.

${ }^{44}$ Still, in all fairness to the anthropological hypothesis, the Hofstede Masculinity index is not a measure of gender inequality per se. Besides being an indicator of how divisoned gender roles are, it also cover aspects such a general emphasis on achievement and assertiveness, which are facets of individualism as well. The inconclusive evidence on "Masculinity" is likely due to these contradicting characteristics of fishermen culture. For a much more direct test of the link to gender roles, see BenYishay et al. (2014).
} 
These findings support the impression from the analysis in the preceeding section that different subsistence strategies in the past may have led societies to develop in different ways vis-a-vis fundamental determinants of productivity; in the present context in terms of average personality traits. Importantly, based on the insights from maritime anthropology summarized in Section 2, "Openness to Experience" is indeed the personality dimension where we would expect the strongest correlation.

We are unaware of any efforts to establish a causal effect of "openness to experience" on growth, and attempting this feat is beyond the scope of the present paper. But it seems plausible a priori that the trait could play a conducive role. For instance, a willingness to engage with new ideas should intuitively support faster technology adoption (Weil, 2009, p. 408-10). Consistent with this prior, individuals with a greater Openness factor tend to be more inclined to entrepreneurial activities as noted above, and micro evidence exists that Openness supports educational achievement (see Almlund et al., 2011 for an overview). Moreover, if the latter result implies a greater inherent inclination towards education, it might have worked to expedite the demographic transition and thus the take-off to sustained growth in societies with a relatively greater mean level of Openness to Experience. ${ }^{45}$ Further work on the link between personality and macroeconomic outcomes, as well as on the possible origins of differences in average personality, would seem like an interesting topic for future analysis.

\section{Conclusions}

We have taken a first pass at examining the long-term consequences of a society having access to a rich "Bounty of the Sea". We find that maritime resources influenced development in the past, and that they still seem to do so today. In the latter respect, however, it appears that it is the bounty of the sea of the ancestors of the current populations which drives the link, not geography per se. These reduced-form results appear to be very robust, and represent - along with the construction of the BoS index itself - the main contribution of the present study.

As a consistency check of our reduced form results, we also explore the link between our ancestry adjusted BoS index and personality traits (individual level charactaristics), culture (group level charactaristics), and institutions supporting property rights (country-wide charactaristics), respectively. Greater "Openness to Experience", a more Individualistic culture, and institutions supportive of private property rights may all have a hand in explaining our reduced form results, as dicussed above. Moreover, the detected correlations seem plausible in light of existing work in anthropology, political science and economics.

\footnotetext{
${ }^{45}$ See Galor (2010) on the link between the inherrent return on skills and comparative development in terms of the timing of the fertility decline and long-run development. See Dalgaard and Strulik (2013) for empirical evidence on the link between the timing of the fertility transition and contemporary comparative development. On climate induced differences in the return to skills, the timing of the fertility transition and contemporary income differences, see Andersen et al. (2015).
} 
The present study may form the basis for future research in a number of directions. First, it would be interesting to explore the link between the bounty of the sea and the spacial distribution of economic activity. In particular, it would be interesting to see if access to rich marine waters, coupled with local inland geography, influenced the location of cities, and helped encourage international trade.

Second, a more disaggregate analysis would also make it possible to offer progress in terms of identification vis-a-vis a link between the bounty of the sea and individual fundamental determinants of productivity. Knudsen (2015) pursues this line of inquiry with respect to the link between the bounty of the sea and individualism; the findings corroborate the macro-level evidence provided above.

Third, in the analysis above we have focused on marine ressources though fishing naturally also can take place in rivers and lakes. It would clearly be interesting to extend the analysis of the present study in this direction. Indeed, this extension may importantly enrich our understanding of how subsistence strategies influences values, as recent experimental work has documented differences within groups of fishermen, depending on whether they are marine fishermen, or fishing in lakes and rivers. ${ }^{46}$ Hence, just as cultural values seem to differ at a more subtle level between agriculturalists specializing in different types of crops (e.g. Talhelm et al., 2014), one may expect to see differences between fishermen targeting different fish species, in different environments.

Finally, one may hypothesize that having had access to a rich bounty of the sea may have influenced the diet (and ultimately dietary traditions) across different societies, which could impact on health - and economic outcomes. This too seems worth exploring in future studies.

\section{References}

[1] Acemoglu, D., 2008. An Introduction to Modern Economic Growth. Princeton University Press.

[2] Acemoglu, D., S. Johnson and J. Robinson, 2001. The Colonial Origins of Comparative Development: An Empirical Investigation. American Economic Review 91, 1369-1401.

[3] Acemoglu, D., S. Johnson and J. Robinson, 2002. Reversal of Fortune: Geography and Institutions in the Making of the Modern World Income Distribution. Quarterly Journal of Economics. 117, 1231-1294.

[4] Acemoglu, D., S. Johnson and J. Robinson, 2005. The Rise of Europe: Atlantic Trade, Institutional Change, and Economic Growth. American Economic Review 95, 546-579.

[5] Acemoglu, D. and S. Johnson, J. Robinson and P. Yared, 2008. Income and Democracy. American Economic Review 98, 808-842

\footnotetext{
${ }^{46}$ See Gneezy, Leibbrandt and List (forthcoming) on the difference between groups of fishermen and Fehr and Leibrandt (2011) on the behavioral traits of lake fishermen.
} 
[6] Acemoglu, D., S. Naidu, P. Restrep and J. Robinson, 2014. Democracy does cause growth. Mimeo (MIT)

[7] Acheson, J. M., 1981. Anthropology of fishing. Annual review of anthropology, 275-316.

[8] Alesina A, P. Giuliano, and N. Nunn, 2013. On the Origins of Gender Roles: Women and the Plough. Quarterly Journal of Economics 128, 469-530.

[9] Andersen, T.B., C-J Dalgaard and P. Selaya, 2015. Climate and the Emergence of Global Income Differences. Review of Economic Studies (Forthcoming)

[10] Almlund, M., A. L. Duckworth, J. J. Heckman, and T. Kautz, 2011. Personality Psychology and Economics. In E. A. Hanushek, S. Machin, and L. Woessmann (Eds.), Handbook of the Economics of Education, Vol. 4, pp. 1-181. Elsevier B.V.

[11] Ashraf, Q. and O. Galor, 2011. Dynamics and Stagnation in the Malthusian Epoch. American Economic Review 101 (5): 2003-41

[12] Ashraf, Q and O. Galor, 2013. The 'Out of Africa' Hypothesis, Human Genetic Diversity, and Comparative Economic Development. American Economic Review 103, 1-46.

[13] Barro, R., forthcoming. Convergence and Modernization. Economic Journal.

[14] Barrett, James H., Rebecca A. Nicholson, and Ruby Cerón-Carrasco, 1999. Archaeo-ichthyological evidence for long-term socioeconomic trends in northern Scotland: 3500 BC to AD 1500. Journal of Archaeological Science $26,353-388$.

[15] Barrett, James H., Alison M. Locker, and Callum M. Roberts, 2004a. The origins of intensive marine fishing in medieval Europe: the English evidence. Proceedings of the Royal Society of London B: Biological Sciences 271, 2417-2421.

[16] Barrett, James H., Alison M. Locker, and Callum M. Roberts, 2004b. Dark Age Economics' revisited: the English fish bone evidence AD 600-1600. Antiquity 78, pp 618-636

[17] Barrett, James, Johnstone, C., Harland, J., Van Neer, W., Ervynck, A., Makowiecki, D., Makowiecki and Richards, M., 2008 Detecting the medieval cod trade: a new method and first results. Journal of Archaeological Science $35,850-861$

[18] BenYishay, A., P. Grosjean, and J. Vecci, 2014. The Fish is the Friend of Matriliny: Reef density predicts matrilineal inheritance across the world and its persistence in Melanesia. Mimeo.

[19] Bleakley, H. and J. Lin, 2012. Portage and path dependence. Quarterly Journal of Economics, 127, 587-644. 
[20] Bolster, J., 2012. The Mortal Sea: Fishing the Atlantic in the Age of Sail. Harvard University Press

[21] Branch, Trevor A., Watson, R., Fulton, E. A., Jennings, S., McGilliard, C. R., Pablico, G. T., R., Daniel, and Tracey, S. R. The trophic fingerprint of marine fisheries. Nature 468.7322 (2010): 431-435.

[22] Bentzen, J., N. Kaarsen and A. Wingender, 2015. Irrigation and Autocracy. Forthcoming: Journal of the European Economic Association.

[23] Chanda, A., C. J. Cook \& L. Putterman, 2014. Persistence of fortune: Accounting for population movements, there was no post-Columbian reversal. American Economic Journal: Macroeconomics, 6, 1-28.

[24] Cheung, William WL, Lam, V. W., Sarmiento, J. L., Kearney, K., Watson, R. E. G., Zeller, D., \& Pauly, D. Large-scale redistribution of maximum fisheries catch potential in the global ocean under climate change. Global Change Biology 16.1 (2010): 24-35.

[25] Cukur, C. S., De Guzman, M. R. T., and Carlo, G., 2004. Religiosity, Values, and Horizontal and Vertical Individualism-Collectivism: A Study of Turkey, the United States, and the Philippines. Journal of social psychology, 144, 613-634.

[26] Dalgaard C-J and H. Strulik, 2013. The History Augmented Solow model. European Economic Review 63, 2013, 134-49

[27] Dalgaard, C-J. and H. Strulik, 2014. Physiological Constraints and Comparative Development. University of Copenhagen Discussion paper No. 14-21.

[28] Dalgaard C-J. and H. Strulik, 2015. The Physiological Foundations of the Wealth of Nations. Journal of Economic Growth 20, 37-73.

[29] Diamond, J., 1997. Guns, Germs and Steel. Penguin Books.

[30] Durante, R., 2010. Risk, Cooperation and the Economic Origins of Social Trust. Mimeo.

[31] Easterly, W., 2001. The middle class consensus and economic development. Journal of Economic Growth 6, $317-335$.

[32] Eggert, Håkan, and Razack B. Lokina. "Small-scale fishermen and risk preferences." Marine Resource Economics (2007): 49-67.

[33] Engerman, S. L. and K. Sokoloff, 2002. Factor Endowments, Inequality, and Paths of Development Among New World Economies. Working Paper 9259, National Bureau of Economic Research.

[34] Enghoff, Inge B., Brian R. MacKenzie, and Einar Eg Nielsen, 2007. The Danish fish fauna during the warm Atlantic period (ca. 7000-3900bc): Forerunner of future changes?. Fisheries Research 87, 167-180. 
[35] Erlandson, J., 2001. The Archaeology of Aquatic Adaptations: Paradigms for a New Millennium. Journal of Archaeological Research 9, 287-350.

[36] Estrada, Marta. 1996 Primary production in the northwestern Mediterranean. Scientia Marina 60.S2: 55-64.

[37] FAO: Torry Research Station, Aberdeen (UK). Yield and nutritional value of the commercially more important fish species. FAO Fisheries Technical Paper. No. 309. Rome, FAO. 1989. 187p.

[38] Food and Agricultural Organization, 2014. The State of World Fisheries and Aquaculture.

[39] Fehr, E. and Leibbrandt, A., 2011. A Field Study on Cooperativeness and Impatience in the Tragedy of the Commons. Journal of Public Economics, 95, 1144-55

[40] Galor, O., 2010. 2008 Lawrence R. Klein Lecture -Comparative Economic Development: Insights from Unified Growth Theory. International Economic Review 51, p. 1-44.

[41] Galor, O. and O. Özak, 2014. The Agricultural Origins of Time Preference. CEPR Discussion Papers 10122.

[42] Goldberg, L. R., 1993. The Structure of Phenotypic Personality Traits. American Psychologist, 48 (1), $26-34$.

[43] Gorodnichenko, Y. and G. Roland, 2011. Individualism, innovation, and long-run growth. Proceedings of the National Academy of Sciences 108, 21316-21319

[44] Gorodnichenko, Y. and G. Roland, 2013. Culture, Institutions and Democratization. Mimeo (University of California, Berkeley)

[45] Gneezy U., A. Leibbrandt J. A. List, Forthcoming. Ode to the Sea: Workplace orgianizations and norms of cooperation. Economic Journal.

[46] Hall, R.E. and C. I. Jones, 1999. Why Do Some Countries Produce So Much More Output Per Worker Than Others? Quarterly Journal of Economics 114, 83-116.

[47] Hoffmann R.C, 1996. Economic Development and Aquatic Ecosystems in Medieval Europe. American Historical Review, 101, pp. 631-669.

[48] Hoffmann, R.C., 2005. A brief history of aquatic resource use in medieval Europe. Helgoland Marine Research, 59 , p. $22-30$.

[49] Hofstede, Geert (2001), Culture's Consequences: Comparing Values, Behaviors, Institutions, and Organizations Across Nations. Second Edition, Thousand Oaks CA: Sage Publications

[50] Hofstede, G. and R. McCrae, 2004. Personality and culture revisited: Linking traits and dimensions of culture. Cross-Cultural Research 38, 52-88. 
[51] Holm, P., 1998. Fiskeriets økonomiske betydning i Danmark 1350-1650. Sjæk'len. Årbog for Fiskeri-og Søfartsmuseet: $8-42$.

[52] Holm P., A.M. Marboe, B. Poulsen and B. R. MacKenzie, 2010. Marine Animal Populations: A New Look Back in Time. Chapter 1 in: A. D. McIntyre (eds) "Life in the World's Oceans: Diversity, Distribution, and Abundance". Wiley Publishers.

[53] Huston, M. A. and S. Wolverton (2009), The global distribution of net primary production: resolving the paradox. Ecological Monographs 79: 343-377.

[54] Hybel, N. and B. Poulsen, 2007. Northern World, Volume 34 : Danish Resources c. 1000-1550 : Growth and Recession. Boston, MA, USA: Brill Academic Publishers.

[55] Inglehart, Ronald, and Christian Welzel. Modernization, cultural change, and democracy: The human development sequence. Cambridge University Press, 2005.

[56] Jennings, Simon, Michel Kaiser, and John D. Reynolds. Marine fisheries ecology. John Wiley \& Sons, 2009.

[57] Keefer, D. K., Moseley, M. E., Richardson, J. B., Satterlee, D. R., \& Day-Lewis, A. 1998. Early maritime economy and El Niño events at Quebrada Tacahuay, Peru. Science 281, 1833-1835.

[58] King, Michael. Fisheries biology, assessment and management. John Wiley \& Sons, 2013.

[59] Knudsen, A.S., 2015. Adapting to the Sea: The rise of individualism in martime societies. Mimeo (University of Copenhagen)

[60] Kurlansky, M., 1997. Cod. Penguin Books.

[61] Lipset, S. M., 1959. Some social requisites of democracy: Economic development and political legitimacy. American Political Science Review 53 69-105.

[62] Litina, A., 2013. Natural Land Productivity, Cooperation and Comparative Development. Mimeo (University of Luxemburg)

[63] Lotze,H., Hunter S. Lenihan, Bruce J. Bourque, Roger H. Bradbury, Richard G. Cooke, Matthew C. Kay, Susan M. Kidwell, Michael X. Kirby, Charles H. Peterson and Jeremy B. C. Jackson, 2006. Depletion, Degradation, and Recovery Potential of Estuaries and Coastal Seas. Science 312, 1806-09.

[64] Marcus, J., 1987. Prehistoric Fishermen in the Kingdom of Huarco: An ancient town on the coast of Peru exported dried fish as part of a regional economic network that predated the Inca conquest American Scientist, 393-401. 
[65] Masters, W. and M. S. McMillan. 2001. Climate and Scale in Economic Growth. Journal of Economic Growth $6(3): 167-86$

[66] Maysha, J., O. Moav and Z. Nieman, 2013. Geography, Transparency and Institutions. CEPR Discussion Paper 9625.

[67] McConney, P., 1997. Social strategies for coping with uncertainty in the barbados small-scale pelagic fishery. In Proceedings of the Gulf and Caribbean Fisheries Institute. Vol. 49. Gulf and Caribbean Fisheries Institute, pp. $99-113$.

[68] McCrae, R.R., 1990. Trait and Trait names: how well is openness to experience represented in natural languages? European Journal of Psychology 4, 119-29.

[69] McCrae, R. R. and O. P. John, 1992. An Introduction to the Five-Factor Model and Its Applications. Journal of Personality 60 (2), 175-215.

[70] McCrae RR, A. Terracciano, and 78 Members of the Personality Profiles of Cultures Project, 2005. Universal features of personality traits from the observer's perspective: Data from 50 cultures. Journal of Personality and Social Psychology 88, 547-561.

[71] McGoodwin, J., 1990. "Crisis in the world's fisheries: People, Problems, and Policies".

[72] Michalopoulos, S., 2012.The origins of ethnolinguistic diversity. American Economic Review 102, 1508-1539.

[73] Michalopoulos, S, L. Putterman and D. Weil, 2014. The Influence of Ancestral Lifeways on Individual Economic Outcomes in Sub-Saharan Africa. Mimeo.

[74] Murdock, G., 1967. Ethnographic atlas. University of Pittsburgh Press

[75] Nicholson, N., E. Soane, M. Fenton-O'Creevy and P. Willman, 2015. Personality and domain-specific risk taking. Journal of Risk Research 8, 157-176

[76] Nunn N, 2014. Historical Development. In: Aghion P, Durlauf S, Handbook of Economic Growth Vol. 2, pp. 347-402. Elsevier, North-Holland.

[77] Olsson, Ola, and D. A. Hibbs, Jr. 2005. Biogeography and Long-Run Economic Development. European Economic Review 49, 909-38

[78] Olsson O. and C. Paik, 2014. A Western Reversal Since the Neolithic? The Long-Run Impact of Early Agriculture. Mimeo (University of Gothenburg)

[79] Pauly, Daniel, Christensen, V., Dalsgaard, J., Froese, R., \& Torres, F. Fishing down marine food webs. Science 279.5352 (1998): 860-863. 
[80] Pauly, Daniel, Ray Hilborn, and Trevor A. Branch. Fisheries: Does catch reflect abundance?. Nature 494.7437 (2013): 303-306.

[81] Poggie Jr, J. J., 1980. Small-scale fishermen's psychocultural characteristics and cooperative formation. Anthropological Quarterly, 20-28.

[82] Putterman, L., 2008. Agriculture, diffusion and development: ripple effects of the Neolithic Revolution. Economica $75,729-748$.

[83] Putterman, L. and D. Weil, 2010. Post-1500 Population Flows and the Long Run Determinants of Economic Growth and Inequality. Quarterly Journal of Economics 125 , 1627-82.

[84] Rafnsson, V. and H. Gunnarsdottir, 1993. Risk of fatal accidents occurring other than at sea among Icelandic seamen. British Medical Journal 306,1379-81.

[85] Rappaport, J. and J.D. Sachs, 2003. The United States as a coastal nation. Journal of Economic growth 8, 5-46.

[86] Ruxton, C.H.S., 2011. The benefits of fish consumption. British Nutrition Foundation Nutrition Bulletin 36, 6-19.

[87] Sethi, Suresh A., Trevor A. Branch, and Reg Watson. Global fishery development patterns are driven by profit but not trophic level. Proceedings of the National Academy of Sciences 107.27 (2010): 12163-12167.

[88] Smith, Adam. "An Inquiry into the Nature and Causes of the Wealth." London 17S6 (1776).

[89] Spolaore, E. and R. Wacziarg, 2013. How Deep are the Roots of Development? Journal of Economic Literature $51,1-45$

[90] Talhelm, T., X. Zhang, S. Oishi, C. Shimin, D. Duan, X. Lan and S. Kitayama, 2014. Large-Scale Psychological Differences Within China Explained by Rice Versus Wheat Agriculture. Science 344, 603-08.

[91] Tittensor, Derek P., Mora, C., Jetz, W., Lotze, H. K., Ricard, D., Berghe, E. V., \& Worm, B. Global patterns and predictors of marine biodiversity across taxa. Nature 466.7310 (2010): 1098-1101.

[92] Tidwell, J.H. and Geoff L. Allan, 2001. Fish as food: aquaculture's contribution: Ecological and economic impacts and contributions of fish farming and capture fisheries. The European Molecular Biology Organization Report 15; 2(11): 958-963.

[93] Ursin, Erik. The tropical, the temperate and the arctic seas as media for fish production. Dana 3 (1984): 43-60.

[94] Valavanis, Vasilis D, Argyris Kapantagakis, Isidora Katara and Andreas Palialexis, 2004. Critical regions: A GIS-based model of marine productivity hotspots. Aquatic Sciences 66: 139-148. 
[95] Watson, Reg, et al. Mapping global fisheries: sharpening our focus. Fish and fisheries 5.2 (2004): 168-177.

[96] Weil, D., 2009. Economic Growth (2nd ed). Persson.

[97] Zhao, H. and S. E. Seibert, 2006. The Big Five Personality Dimensions and Entrepreneurial Status: A MetaAnalytical Review. Journal of Applied Psychology 91, 259-71. 
Table 1. Validation of BoS: Harvesting marine resources

\begin{tabular}{|c|c|c|c|c|c|c|}
\hline \multirow[b]{2}{*}{ Dep. variable: (log) } & 1 & 2 & 3 & 4 & 5 & 6 \\
\hline & \multicolumn{2}{|c|}{ Fish landings (tons/year) } & \multicolumn{4}{|c|}{ Fish landings (tons/year) } \\
\hline \multirow{2}{*}{$\begin{array}{l}\text { Dataset: } \\
\text { Period: }\end{array}$} & \multirow{2}{*}{$\begin{array}{c}\text { ICES } \\
1903-1939\end{array}$} & \multirow{2}{*}{$\begin{array}{c}\text { IHS } \\
1900-1939\end{array}$} & \multicolumn{4}{|c|}{ FAO } \\
\hline & & & $1950 s$ & 1960-2009 & 1950s & 1960-2009 \\
\hline \multirow[t]{2}{*}{ BoS index } & 0,665 & 0,443 & 0,35 & 0,412 & 0,302 & 0,282 \\
\hline & $(0.001)$ & $(0.005)$ & $(0.000)$ & $(0.000)$ & $(0.000)$ & $(0.000)$ \\
\hline \multirow[t]{2}{*}{ (log) EEZ area (sq km) } & 0,49 & 0,401 & 0,446 & 0,566 & 0,56 & 0,728 \\
\hline & $(0.095)$ & (0.019) & $(0.000)$ & $(0.000)$ & $(0.000)$ & $(0.000)$ \\
\hline 1 [Continent = Africa $]$ & & & & & 0,02 & $-0,22$ \\
\hline \multirow[t]{2}{*}{$1[$ Continent $=$ Asia $]$} & & & & & 0,177 & 0,022 \\
\hline & & & & & $(0.102)$ & $(0.698)$ \\
\hline \multirow[t]{2}{*}{$1[$ Continent $=$ Oceania $]$} & & & & & $-0,275$ & $-0,419$ \\
\hline & & & & & $(0.006)$ & $(0.000)$ \\
\hline \multirow[t]{2}{*}{$1[$ Continent $=$ Americas $]$} & & & & & $-0,071$ & $-0,299$ \\
\hline & & & & & $(0.513)$ & $(0.000)$ \\
\hline Continental FEs & No & No & No & No & Yes & Yes \\
\hline Observations & 17 & 36 & 162 & 162 & 162 & 162 \\
\hline R-squared & 0,38 & 0,25 & 0,31 & 0,47 & 0,42 & 0,63 \\
\hline
\end{tabular}

Notes: OLS regressions. All regressions include a constant. Robust standard errors. Standardized beta coefficients displayed.

P-values in parentheses. 
Table 2. Validation of BoS: Labor force allocation

\begin{tabular}{|c|c|c|c|c|}
\hline & 1 & 2 & 3 & 4 \\
\hline Dep. Variable: (log) & \multicolumn{4}{|c|}{ Fishermen } \\
\hline \multirow[t]{2}{*}{ BoS index (100 km buffer) } & 0,349 & 0,363 & 0,336 & 0,352 \\
\hline & $(0.000)$ & $(0.000)$ & $(0.000)$ & $(0.000)$ \\
\hline \multirow{2}{*}{ (log) Population } & 0,289 & 0,500 & & \\
\hline & $(0.000)$ & $(0.000)$ & & \\
\hline \multirow[t]{2}{*}{ (log) Employment } & & & 0,34 & 0,605 \\
\hline & & & $(0.000)$ & $(0.000)$ \\
\hline \multirow[t]{2}{*}{ (log) $100 \mathrm{~km}$ buffer area (sq km) } & 0,308 & 0,352 & 0,309 & 0,348 \\
\hline & $(0.000)$ & $(0.000)$ & $(0.000)$ & $(0.000)$ \\
\hline Observations & 309 & 309 & 309 & 309 \\
\hline R-squared & 0,58 & 0,62 & 0,57 & 0,61 \\
\hline Survey year fixed effects & Yes & Yes & Yes & Yes \\
\hline Country fixed effects & No & Yes & No & Yes \\
\hline Number of regions & 80 & 80 & 80 & 80 \\
\hline
\end{tabular}

Notes: OLS regressions. All regressions include a constant. Robust standard errors. Standardized beta coefficients

$\mathrm{P}$-values in parentheses. 
Table 3. Validating the BoS Index: Food supply in traditional ethnic societies

\begin{tabular}{|c|c|c|c|c|c|c|c|c|c|c|}
\hline \multirow[b]{3}{*}{ Dep. Var: } & 1 & 2 & 3 & 4 & 5 & 6 & 7 & 8 & 9 & 10 \\
\hline & \multicolumn{10}{|c|}{ Dependence on: } \\
\hline & Gathering & Hunting & Fishing & $\begin{array}{c}\text { Animal } \\
\text { Husbandry }\end{array}$ & Agriculture & Gathering & Hunting & Fishing & $\begin{array}{c}\text { Animal } \\
\text { Husbandry }\end{array}$ & Agriculture \\
\hline Dataset: & \multicolumn{5}{|c|}{ Standard Cross Cultural Sample } & \multicolumn{5}{|c|}{ Ethnographic Atlas } \\
\hline \multirow[t]{2}{*}{ BoS index, 100 km buffer } & 0,291 & 0,283 & 0,205 & $-0,175$ & $-0,286$ & 0,466 & 0,212 & 0,083 & $-0,132$ & $-0,329$ \\
\hline & $(0.008)$ & $(0.003)$ & $(0.024)$ & $(0.052)$ & $(0.003)$ & $(0.000)$ & $(0.000)$ & $(0.083)$ & $(0.000)$ & $(0.000)$ \\
\hline \multirow[t]{2}{*}{ (log) Buffer ocean area } & 0,091 & $-0,065$ & 0,008 & $-0,012$ & $-0,007$ & $-0,024$ & $-0,14$ & $-0,02$ & 0,063 & 0,051 \\
\hline & $(0.478)$ & $(0.596)$ & $(0.921)$ & $(0.908)$ & $(0.954)$ & $(0.558)$ & $(0.007)$ & $(0.598)$ & (0.109) & $(0.243)$ \\
\hline \multirow[t]{2}{*}{ (log) Distance to coast } & 0,032 & 0,058 & $-0,557$ & 0,259 & 0,189 & 0,084 & 0,034 & $-0,483$ & 0,182 & 0,159 \\
\hline & $(0.783)$ & $(0.671)$ & $(0.000)$ & $(0.030)$ & $(0.116)$ & $(0.058)$ & $(0.437)$ & $(0.000)$ & $(0.000)$ & $(0.000)$ \\
\hline Survey year FEs & Yes & Yes & Yes & Yes & Yes & Yes & Yes & Yes & Yes & Yes \\
\hline Continent FEs & No & No & No & No & No & Yes & Yes & Yes & Yes & Yes \\
\hline Observations & 100 & 100 & 100 & 100 & 100 & 545 & 545 & 545 & 545 & 545 \\
\hline R-squared & 0,09 & 0,10 & 0,35 & 0,10 & 0,12 & 0,36 & 0,39 & 0,42 & 0,36 & 0,35 \\
\hline
\end{tabular}

Notes: OLS regressions. All regressions include a constant. Robust standard errors. Standardized beta coefficients displayed.

P-values in parentheses. 


\begin{tabular}{|c|c|c|c|c|c|c|c|c|c|c|}
\hline \multirow[b]{2}{*}{ Dep. Var.: (log) } & (1) & (2) & (3) & (4) & (5) & (6) & (7) & (8) & (9) & (10) \\
\hline & \multicolumn{10}{|c|}{ Population density 1500 C.E. } \\
\hline \multirow[t]{2}{*}{ BoS index } & 0.204 & 0.137 & 0.154 & 0.154 & 0.187 & 0.183 & & & & \\
\hline & $(0.029)$ & $(0.051)$ & $(0.040)$ & $(0.012)$ & $(0.004)$ & $(0.010)$ & & & & \\
\hline \multirow[t]{2}{*}{ Bos index, top fish } & & & & & & & 0.214 & 0.208 & & \\
\hline & & & & & & & $(0.010)$ & $(0.002)$ & & \\
\hline \multirow[t]{2}{*}{ Bos index, $10 \mathrm{~km}$ buffer } & & & & & & & & & 0.263 & 0.235 \\
\hline & & & & & & & & & $(0.000)$ & $(0.000)$ \\
\hline \multirow[t]{2}{*}{ Soil suitability } & 0.239 & 0.225 & 0.238 & 0.251 & 0.247 & 0.304 & 0.236 & 0.284 & 0.239 & 0.292 \\
\hline & $(0.001)$ & $(0.002)$ & $(0.001)$ & $(0.000)$ & $(0.000)$ & $(0.000)$ & $(0.000)$ & $(0.001)$ & $(0.000)$ & $(0.000)$ \\
\hline \multirow[t]{2}{*}{ EEZ area } & -0.084 & 0.098 & 0.206 & 0.017 & 0.133 & 0.103 & 0.119 & 0.089 & & \\
\hline & $(0.553)$ & $(0.405)$ & $(0.077)$ & $(0.895)$ & $(0.274)$ & $(0.403)$ & $(0.317)$ & $(0.447)$ & & \\
\hline \multirow[t]{2}{*}{ Buffer area } & & & & & & & & & 0.032 & -0.014 \\
\hline & & & & & & & & & $(0.599)$ & $(0.816)$ \\
\hline \multirow[t]{2}{*}{ Land area } & -0.304 & -0.335 & -0.402 & -0.139 & -0.197 & -0.209 & -0.193 & -0.209 & -0.120 & -0.118 \\
\hline & $(0.064)$ & $(0.004)$ & $(0.000)$ & $(0.209)$ & $(0.061)$ & $(0.068)$ & $(0.060)$ & $(0.051)$ & $(0.114)$ & $(0.163)$ \\
\hline \multirow[t]{2}{*}{ Latitude (abs) } & & & & -0.525 & -0.525 & -0.385 & -0.372 & -0.190 & -0.540 & -0.389 \\
\hline & & & & $(0.000)$ & $(0.000)$ & $(0.000)$ & $(0.000)$ & $(0.082)$ & $(0.000)$ & $(0.000)$ \\
\hline \multirow[t]{2}{*}{ Landlocked } & & & & 0.016 & 0.074 & & 0.129 & & 0.127 & \\
\hline & & & & (0.829) & $(0.278)$ & & $(0.092)$ & & $(0.076)$ & \\
\hline \multirow[t]{2}{*}{ Land near waterways (\%) } & & & & 0.174 & 0.215 & 0.184 & 0.209 & 0.186 & 0.227 & 0.198 \\
\hline & & & & $(0.042)$ & $(0.014)$ & $(0.040)$ & $(0.014)$ & (0.031) & $(0.007)$ & $(0.019)$ \\
\hline \multirow[t]{2}{*}{ Yrs since Neolithic } & & & 0.336 & & 0.351 & 0.296 & 0.373 & 0.336 & 0.355 & 0.299 \\
\hline & & & $(0.000)$ & & $(0.000)$ & $(0.001)$ & $(0.000)$ & $(0.000)$ & $(0.000)$ & $(0.001)$ \\
\hline Continental FE's & No & Yes & Yes & Yes & Yes & Yes & Yes & Yes & Yes & Yes \\
\hline Sample & Full & Full & Full & Full & Full & No landlock & Full & No landlock & Full & No landlock \\
\hline Observations & 150 & 150 & 150 & 150 & 150 & 113 & 150 & 113 & 150 & 113 \\
\hline R-squared & 0.255 & 0.511 & 0.549 & 0.622 & 0.661 & 0.702 & 0.654 & 0.704 & 0.678 & 0.723 \\
\hline
\end{tabular}

Notes: standardized regressions coefficients reported; p-values in paranthesis. All specifications include a constant term. Columns marked

"No Landlock" excludes landlocked nations. 
Table 5. Bounty of the Sea and Contemporary Development
(1)
(2)
(3)
(4)
(5)
(6)
(7)
(8)
(10)

Dep. Var.: $(\log )$

GDP per capita, 2005

\begin{tabular}{|c|c|c|c|c|c|c|c|c|c|c|}
\hline BoS index & $\begin{array}{c}0.381 \\
(0.000)\end{array}$ & $\begin{array}{c}0.176 \\
(0.000)\end{array}$ & $\begin{array}{c}0.178 \\
(0.000)\end{array}$ & $\begin{array}{c}0.088 \\
(0.038)\end{array}$ & $\begin{array}{c}0.092 \\
(0.026)\end{array}$ & $\begin{array}{c}0.136 \\
(0.005)\end{array}$ & & & & \\
\hline BoS index, top fish & & & & & & & $\begin{array}{c}0.074 \\
(0.357)\end{array}$ & $\begin{array}{c}0.077 \\
(0.294)\end{array}$ & & \\
\hline BoS index, $10 \mathrm{~km}$ buffer & & & & & & & & & $\begin{array}{c}0.111 \\
(0.023)\end{array}$ & $\begin{array}{c}0.139 \\
(0.007)\end{array}$ \\
\hline Soil suitability & $\begin{array}{c}0.020 \\
(0.819)\end{array}$ & $\begin{array}{l}-0.205 \\
(0.001)\end{array}$ & $\begin{array}{c}-0.206 \\
(0.001)\end{array}$ & $\begin{array}{l}-0.256 \\
(0.000)\end{array}$ & $\begin{array}{l}-0.259 \\
(0.000)\end{array}$ & $\begin{array}{l}-0.313 \\
(0.000)\end{array}$ & $\begin{array}{c}-0.262 \\
(0.000)\end{array}$ & $\begin{array}{c}-0.314 \\
(0.000)\end{array}$ & $\begin{array}{l}-0.259 \\
(0.000)\end{array}$ & $\begin{array}{c}-0.312 \\
(0.000)\end{array}$ \\
\hline EEZ area & $\begin{array}{c}0.282 \\
(0.011)\end{array}$ & $\begin{array}{c}0.118 \\
(0.337)\end{array}$ & $\begin{array}{c}0.129 \\
(0.309)\end{array}$ & $\begin{array}{c}0.058 \\
(0.491)\end{array}$ & $\begin{array}{c}0.071 \\
(0.435)\end{array}$ & $\begin{array}{c}0.093 \\
(0.441)\end{array}$ & $\begin{array}{c}0.061 \\
(0.500)\end{array}$ & $\begin{array}{c}0.070 \\
(0.542)\end{array}$ & & \\
\hline Buffer area & & & & & & & & & $\begin{array}{c}0.033 \\
(0.603)\end{array}$ & $\begin{array}{c}0.042 \\
(0.626)\end{array}$ \\
\hline Land area & $\begin{array}{l}-0.116 \\
(0.232)\end{array}$ & $\begin{array}{c}-0.042 \\
(0.661)\end{array}$ & $\begin{array}{l}-0.048 \\
(0.621)\end{array}$ & $\begin{array}{c}0.014 \\
(0.858)\end{array}$ & $\begin{array}{c}0.008 \\
(0.923)\end{array}$ & $\begin{array}{l}-0.000 \\
(0.999)\end{array}$ & $\begin{array}{c}0.014 \\
(0.869)\end{array}$ & $\begin{array}{c}0.015 \\
(0.891)\end{array}$ & $\begin{array}{c}0.038 \\
(0.577)\end{array}$ & $\begin{array}{c}0.039 \\
(0.649)\end{array}$ \\
\hline Latitude (abs) & & & & $\begin{array}{c}0.411 \\
(0.000)\end{array}$ & $\begin{array}{c}0.409 \\
(0.000)\end{array}$ & $\begin{array}{c}0.395 \\
(0.000)\end{array}$ & $\begin{array}{c}0.471 \\
(0.000)\end{array}$ & $\begin{array}{c}0.495 \\
(0.000)\end{array}$ & $\begin{array}{c}0.408 \\
(0.000)\end{array}$ & $\begin{array}{c}0.402 \\
(0.000)\end{array}$ \\
\hline Landlocked & & & & $\begin{array}{l}-0.010 \\
(0.866)\end{array}$ & $\begin{array}{c}-0.002 \\
(0.972)\end{array}$ & & $\begin{array}{c}0.006 \\
(0.941)\end{array}$ & & $\begin{array}{c}0.016 \\
(0.807)\end{array}$ & \\
\hline Land near waterways (\%) & & & & $\begin{array}{c}0.238 \\
(0.010)\end{array}$ & $\begin{array}{c}0.243 \\
(0.008)\end{array}$ & $\begin{array}{c}0.215 \\
(0.019)\end{array}$ & $\begin{array}{c}0.245 \\
(0.009)\end{array}$ & $\begin{array}{c}0.228 \\
(0.015)\end{array}$ & $\begin{array}{c}0.249 \\
(0.006)\end{array}$ & $\begin{array}{c}0.225 \\
(0.012)\end{array}$ \\
\hline Yrs since Neolithic & & & $\begin{array}{c}0.036 \\
(0.733)\end{array}$ & & $\begin{array}{c}0.041 \\
(0.652)\end{array}$ & $\begin{array}{c}0.097 \\
(0.361)\end{array}$ & $\begin{array}{c}0.044 \\
(0.644)\end{array}$ & $\begin{array}{c}0.096 \\
(0.383)\end{array}$ & $\begin{array}{c}0.041 \\
(0.654)\end{array}$ & $\begin{array}{c}0.097 \\
(0.352)\end{array}$ \\
\hline Continental FE's & No & Yes & Yes & Yes & Yes & Yes & Yes & Yes & Yes & Yes \\
\hline Sample & Full & Full & Full & Full & Full & No landlocked & Full & No landlocked & Full & No landlocked \\
\hline Observations & 140 & 140 & 140 & 140 & 140 & 103 & 140 & 103 & 140 & 103 \\
\hline R-squared & 0.203 & 0.627 & 0.628 & 0.692 & 0.692 & 0.686 & 0.689 & 0.676 & 0.694 & 0.688 \\
\hline
\end{tabular}

Notes: standardized regressions coefficients reported; $p$-values in paranthesis. All specifications include a constant term. Columns marked

"No Landlock" excludes landlocked nations. 


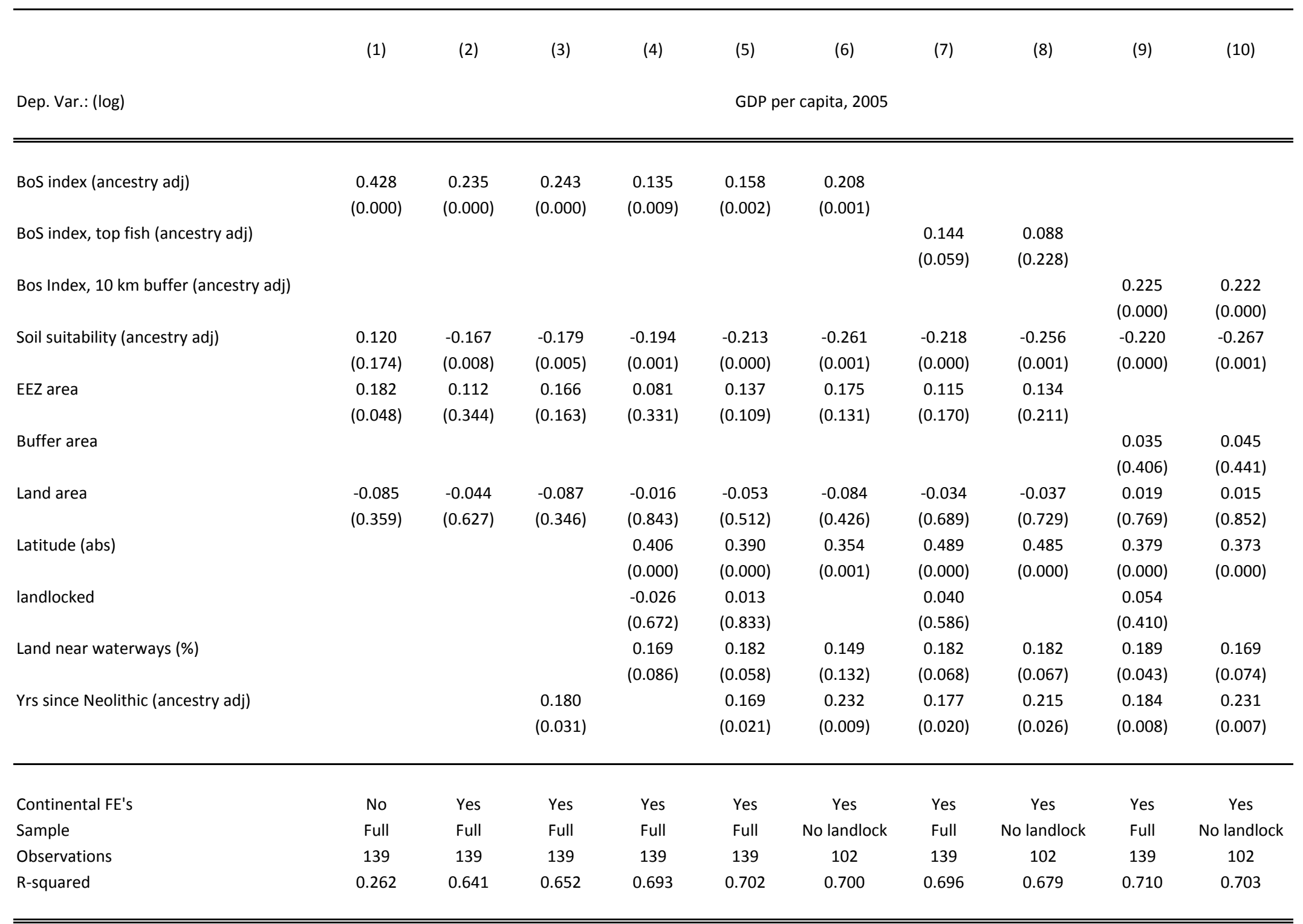

Notes: standardized regressions coefficients reported; p-values in paranthesis. All specifications include a constant term. Columns marked "No landlock"

excludes landlocked nations. 
Table 7. Bounty of the Sea and Contemporary Development: Place or People?

$\begin{array}{llllllllll}(1) & (2) & \text { (3) } & \text { (4) } & \text { (5) } & \text { (6) } & \text { (7) } & \text { (8) } & \text { (9) } & \text { (10) }\end{array}$

Dep. Var.: $(\log )$

GDP per capita, 2005

\begin{tabular}{|c|c|c|c|c|c|c|c|c|c|c|}
\hline Bos Index (ancestry adj) & $\begin{array}{c}0.479 \\
(0.000)\end{array}$ & $\begin{array}{c}0.379 \\
(0.020)\end{array}$ & $\begin{array}{c}0.431 \\
(0.008)\end{array}$ & $\begin{array}{c}0.260 \\
(0.052)\end{array}$ & $\begin{array}{c}0.304 \\
(0.026)\end{array}$ & $\begin{array}{c}0.311 \\
(0.010)\end{array}$ & & & & \\
\hline BoS index & $\begin{array}{l}-0.055 \\
(0.579)\end{array}$ & $\begin{array}{l}-0.150 \\
(0.359)\end{array}$ & $\begin{array}{c}-0.194 \\
(0.230)\end{array}$ & $\begin{array}{l}-0.133 \\
(0.294)\end{array}$ & $\begin{array}{l}-0.154 \\
(0.231)\end{array}$ & $\begin{array}{l}-0.107 \\
(0.313)\end{array}$ & & & & \\
\hline Bos Index, top fish (ancestry adj) & & & & & & & $\begin{array}{c}0.274 \\
(0.027)\end{array}$ & $\begin{array}{c}0.146 \\
(0.306)\end{array}$ & & \\
\hline Bos index, top fish & & & & & & & $\begin{array}{c}-0.173 \\
(0.231)\end{array}$ & $\begin{array}{l}-0.065 \\
(0.681)\end{array}$ & & \\
\hline Bos index, $10 \mathrm{~km}$ buffer (ancestry adj) & & & & & & & & & $\begin{array}{c}0.370 \\
(0.004)\end{array}$ & $\begin{array}{c}0.262 \\
(0.007)\end{array}$ \\
\hline Bos Index, $10 \mathrm{~km}$ buffer & & & & & & & & & $\begin{array}{c}0.014 \\
(0.772)\end{array}$ & $\begin{array}{c}0.038 \\
(0.539)\end{array}$ \\
\hline Soil suitability (ancestry adj) & $\begin{array}{c}0.122 \\
(0.174)\end{array}$ & $\begin{array}{c}-0.164 \\
(0.010)\end{array}$ & $\begin{array}{c}-0.176 \\
(0.006)\end{array}$ & $\begin{array}{l}-0.187 \\
(0.003)\end{array}$ & $\begin{array}{c}-0.206 \\
(0.001)\end{array}$ & $\begin{array}{l}-0.254 \\
(0.001)\end{array}$ & $\begin{array}{l}-0.207 \\
(0.001)\end{array}$ & $\begin{array}{l}-0.253 \\
(0.001)\end{array}$ & $\begin{array}{c}-0.214 \\
(0.001)\end{array}$ & $\begin{array}{l}-0.265 \\
(0.001)\end{array}$ \\
\hline EEZ area & $\begin{array}{c}0.170 \\
(0.090)\end{array}$ & $\begin{array}{c}0.105 \\
(0.373)\end{array}$ & $\begin{array}{c}0.162 \\
(0.166)\end{array}$ & $\begin{array}{c}0.074 \\
(0.375)\end{array}$ & $\begin{array}{c}0.132 \\
(0.127)\end{array}$ & $\begin{array}{c}0.171 \\
(0.140)\end{array}$ & $\begin{array}{c}0.098 \\
(0.274)\end{array}$ & $\begin{array}{c}0.126 \\
(0.274)\end{array}$ & & \\
\hline Buffer area & & & & & & & & & $\begin{array}{c}-0.154 \\
(0.184)\end{array}$ & $\begin{array}{c}-0.041 \\
(0.625)\end{array}$ \\
\hline Land ara & $\begin{array}{l}-0.082 \\
(0.389)\end{array}$ & $\begin{array}{c}-0.046 \\
(0.603)\end{array}$ & $\begin{array}{l}-0.095 \\
(0.293)\end{array}$ & $\begin{array}{l}-0.023 \\
(0.770)\end{array}$ & $\begin{array}{l}-0.063 \\
(0.424)\end{array}$ & $\begin{array}{l}-0.092 \\
(0.374)\end{array}$ & $\begin{array}{l}-0.025 \\
(0.775)\end{array}$ & $\begin{array}{l}-0.034 \\
(0.756)\end{array}$ & $\begin{array}{c}0.019 \\
(0.781)\end{array}$ & $\begin{array}{c}0.015 \\
(0.855)\end{array}$ \\
\hline Latitude (abs) & & & & $\begin{array}{c}0.406 \\
(0.000)\end{array}$ & $\begin{array}{c}0.389 \\
(0.000)\end{array}$ & $\begin{array}{c}0.354 \\
(0.001)\end{array}$ & $\begin{array}{c}0.461 \\
(0.000)\end{array}$ & $\begin{array}{c}0.477 \\
(0.000)\end{array}$ & $\begin{array}{c}0.378 \\
(0.000)\end{array}$ & $\begin{array}{c}0.374 \\
(0.000)\end{array}$ \\
\hline landlocked & & & & $\begin{array}{c}-0.042 \\
(0.490)\end{array}$ & $\begin{array}{l}-0.004 \\
(0.948)\end{array}$ & & $\begin{array}{c}0.000 \\
(0.999)\end{array}$ & & $\begin{array}{c}0.033 \\
(0.614)\end{array}$ & \\
\hline Land near waterways (\%) & & & & $\begin{array}{c}0.154 \\
(0.119)\end{array}$ & $\begin{array}{c}0.166 \\
(0.086)\end{array}$ & $\begin{array}{c}0.138 \\
(0.170)\end{array}$ & $\begin{array}{c}0.175 \\
(0.067)\end{array}$ & $\begin{array}{c}0.178 \\
(0.063)\end{array}$ & $\begin{array}{c}0.173 \\
(0.065)\end{array}$ & $\begin{array}{c}0.164 \\
(0.086)\end{array}$ \\
\hline Yrs since Neolithic (ancestry adj) & & & $\begin{array}{c}0.198 \\
(0.016)\end{array}$ & & $\begin{array}{c}0.177 \\
(0.017)\end{array}$ & $\begin{array}{c}0.236 \\
(0.008)\end{array}$ & $\begin{array}{c}0.170 \\
(0.028)\end{array}$ & $\begin{array}{c}0.213 \\
(0.027)\end{array}$ & $\begin{array}{c}0.188 \\
(0.007)\end{array}$ & $\begin{array}{c}0.231 \\
(0.007)\end{array}$ \\
\hline Continental FE's & No & Yes & Yes & Yes & Yes & Yes & Yes & Yes & Yes & Yes \\
\hline Sample & Full & Full & Full & Full & Full & No landlock & Full & No landlock & Full & No landlock \\
\hline Observations & 139 & 139 & 139 & 139 & 139 & 102 & 139 & 102 & 139 & 102 \\
\hline R-squared & 0.263 & 0.644 & 0.658 & 0.695 & 0.705 & 0.702 & 0.700 & 0.680 & 0.714 & 0.703 \\
\hline
\end{tabular}

Notes: Standardized regression coefficients; p-values in paranthesis. Underlying standard deviations robust to heteroscedasticity. In columns marked

"No Landlock" we omit all landlocked nations. 
Table 8. The Bounty of the Sea and Institutions

\begin{tabular}{|c|c|c|c|c|c|c|c|c|c|}
\hline \multirow[b]{2}{*}{ Dep. Var: } & (1) & $(2)$ & (3) & (4) & (5) & (6) & (7) & (8) & (9) \\
\hline & \multicolumn{3}{|c|}{ Constraints on the Executive } & \multicolumn{3}{|c|}{ Democracy } & \multicolumn{3}{|c|}{ Rule of Law } \\
\hline \multirow[t]{2}{*}{ BoS index (ancestry adj) } & 0.215 & 0.104 & 0.138 & 0.238 & 0.150 & 0.146 & 0.359 & 0.304 & 0.190 \\
\hline & $(0.000)$ & $(0.145)$ & $(0.025)$ & $(0.000)$ & $(0.032)$ & $(0.021)$ & $(0.000)$ & $(0.000)$ & $(0.000)$ \\
\hline \multirow[t]{2}{*}{ Soil suitability (ancestry adj) } & 0.109 & 0.111 & 0.160 & 0.047 & 0.038 & 0.109 & 0.231 & 0.245 & 0.150 \\
\hline & $(0.148)$ & $(0.139)$ & $(0.038)$ & $(0.535)$ & $(0.628)$ & $(0.161)$ & $(0.138)$ & $(0.047)$ & $(0.100)$ \\
\hline \multirow[t]{2}{*}{ EEZ area } & 0.182 & 0.058 & 0.147 & 0.184 & 0.086 & 0.142 & -0.097 & -0.150 & 0.024 \\
\hline & $(0.198)$ & $(0.626)$ & $(0.200)$ & $(0.270)$ & $(0.567)$ & $(0.290)$ & $(0.209)$ & $(0.055)$ & $(0.706)$ \\
\hline \multirow[t]{2}{*}{ Land area } & -0.167 & -0.060 & -0.153 & -0.136 & -0.039 & -0.120 & -0.204 & -0.201 & -0.172 \\
\hline & $(0.125)$ & $(0.592)$ & $(0.080)$ & $(0.268)$ & $(0.754)$ & $(0.221)$ & $(0.118)$ & $(0.131)$ & $(0.035)$ \\
\hline \multirow[t]{2}{*}{ Yrs since Neolithic (ancestry adj) } & & -0.260 & & & -0.195 & & & 0.061 & \\
\hline & & $(0.012)$ & & & $(0.044)$ & & & $(0.524)$ & \\
\hline \multirow[t]{2}{*}{ Latitude (abs) } & & 0.298 & & & 0.247 & & & 0.398 & \\
\hline & & $(0.013)$ & & & (0.029) & & & $(0.000)$ & \\
\hline \multirow[t]{2}{*}{ landlocked } & & -0.057 & & & -0.015 & & & 0.079 & \\
\hline & & $(0.467)$ & & & $(0.848)$ & & & $(0.347)$ & \\
\hline \multirow[t]{2}{*}{ Land near waterways (\%) } & & 0.151 & & & 0.160 & & & 0.181 & \\
\hline & & $(0.141)$ & & & (0.139) & & & $(0.084)$ & \\
\hline \multirow[t]{2}{*}{ log GDP per capita } & & & 0.312 & & & 0.374 & & & 0.719 \\
\hline & & & (0.019) & & & $(0.002)$ & & & $(0.000)$ \\
\hline Continental FE's & Yes & Yes & Yes & Yes & Yes & Yes & Yes & Yes & Yes \\
\hline Observations & 136 & 136 & 136 & 136 & 136 & 136 & 139 & 139 & 139 \\
\hline R-squared & 0.489 & 0.539 & 0.523 & 0.507 & 0.542 & 0.556 & 0.517 & 0.574 & 0.703 \\
\hline
\end{tabular}

Notes: Standardized regression coefficients; $p$-values in paranthesis. Underlying standard deviations robust to heteroscedasticity. 
Table 9. The Bounty of the Sea and Cultural Values

\begin{tabular}{|c|c|c|c|c|c|c|c|c|c|c|c|c|c|c|c|}
\hline & (1) & (2) & (3) & (4) & (5) & (6) & (7) & (8) & (9) & (10) & (11) & (12) & (13) & (14) & (15) \\
\hline Dep. Var.: & MAS & MAS & MAS & IDV & IDV & IDV & PDI & PDI & PDI & UAI & UAI & UAI & LTO & LTO & LTO \\
\hline BoS index (ancestry adj) & $\begin{array}{l}-0.147 \\
(0.324)\end{array}$ & $\begin{array}{c}0.063 \\
(0.678)\end{array}$ & $\begin{array}{l}-0.225 \\
(0.165)\end{array}$ & $\begin{array}{c}0.253 \\
(0.011)\end{array}$ & $\begin{array}{c}0.208 \\
(0.056)\end{array}$ & $\begin{array}{c}0.120 \\
(0.205)\end{array}$ & $\begin{array}{l}-0.179 \\
(0.133)\end{array}$ & $\begin{array}{l}-0.088 \\
(0.418)\end{array}$ & $\begin{array}{l}-0.012 \\
(0.922)\end{array}$ & $\begin{array}{l}-0.207 \\
(0.183)\end{array}$ & $\begin{array}{l}-0.276 \\
(0.149)\end{array}$ & $\begin{array}{l}-0.225 \\
(0.159)\end{array}$ & $\begin{array}{c}0.126 \\
(0.250)\end{array}$ & $\begin{array}{c}0.159 \\
(0.160)\end{array}$ & $\begin{array}{c}0.157 \\
(0.157)\end{array}$ \\
\hline Soil suitability (ancestry adj) & $\begin{array}{c}0.338 \\
(0.012)\end{array}$ & $\begin{array}{c}0.121 \\
(0.331)\end{array}$ & $\begin{array}{c}0.367 \\
(0.009)\end{array}$ & $\begin{array}{l}-0.119 \\
(0.175)\end{array}$ & $\begin{array}{l}-0.191 \\
(0.051)\end{array}$ & $\begin{array}{l}-0.069 \\
(0.387)\end{array}$ & $\begin{array}{c}0.325 \\
(0.000)\end{array}$ & $\begin{array}{c}0.433 \\
(0.000)\end{array}$ & $\begin{array}{c}0.263 \\
(0.001)\end{array}$ & $\begin{array}{c}0.467 \\
(0.000)\end{array}$ & $\begin{array}{c}0.483 \\
(0.002)\end{array}$ & $\begin{array}{c}0.474 \\
(0.000)\end{array}$ & $\begin{array}{c}0.283 \\
(0.000)\end{array}$ & $\begin{array}{c}0.268 \\
(0.001)\end{array}$ & $\begin{array}{c}0.266 \\
(0.001)\end{array}$ \\
\hline EEZ area & $\begin{array}{c}0.104 \\
(0.625)\end{array}$ & $\begin{array}{c}0.222 \\
(0.372)\end{array}$ & $\begin{array}{c}0.060 \\
(0.735)\end{array}$ & $\begin{array}{c}0.042 \\
(0.838)\end{array}$ & $\begin{array}{c}0.096 \\
(0.549)\end{array}$ & $\begin{array}{l}-0.033 \\
(0.802)\end{array}$ & $\begin{array}{c}0.103 \\
(0.526)\end{array}$ & $\begin{array}{c}0.027 \\
(0.799)\end{array}$ & $\begin{array}{c}0.197 \\
(0.050)\end{array}$ & $\begin{array}{c}0.195 \\
(0.260)\end{array}$ & $\begin{array}{c}0.276 \\
(0.139)\end{array}$ & $\begin{array}{c}0.185 \\
(0.268)\end{array}$ & $\begin{array}{c}0.152 \\
(0.283)\end{array}$ & $\begin{array}{c}0.050 \\
(0.711)\end{array}$ & $\begin{array}{c}0.167 \\
(0.236)\end{array}$ \\
\hline Land area & $\begin{array}{c}0.008 \\
(0.967)\end{array}$ & $\begin{array}{c}0.049 \\
(0.814)\end{array}$ & $\begin{array}{c}0.023 \\
(0.884)\end{array}$ & $\begin{array}{c}0.116 \\
(0.598)\end{array}$ & $\begin{array}{c}0.032 \\
(0.889)\end{array}$ & $\begin{array}{c}0.142 \\
(0.360)\end{array}$ & $\begin{array}{c}0.102 \\
(0.457)\end{array}$ & $\begin{array}{c}0.187 \\
(0.191)\end{array}$ & $\begin{array}{c}0.069 \\
(0.295)\end{array}$ & $\begin{array}{l}-0.146 \\
(0.379)\end{array}$ & $\begin{array}{l}-0.281 \\
(0.175)\end{array}$ & $\begin{array}{l}-0.143 \\
(0.389)\end{array}$ & $\begin{array}{c}0.105 \\
(0.384)\end{array}$ & $\begin{array}{c}0.204 \\
(0.106)\end{array}$ & $\begin{array}{c}0.099 \\
(0.407)\end{array}$ \\
\hline Yrs since Neolithic (ancestry adj) & & $\begin{array}{c}0.173 \\
(0.153)\end{array}$ & & & $\begin{array}{c}0.113 \\
(0.345)\end{array}$ & & & $\begin{array}{l}-0.198 \\
(0.101)\end{array}$ & & & $\begin{array}{c}0.152 \\
(0.349)\end{array}$ & & & $\begin{array}{l}-0.265 \\
(0.025)\end{array}$ & \\
\hline Latitude (abs) & & $\begin{array}{l}-0.220 \\
(0.235)\end{array}$ & & & $\begin{array}{c}0.635 \\
(0.000)\end{array}$ & & & $\begin{array}{l}-0.759 \\
(0.000)\end{array}$ & & & $\begin{array}{l}-0.006 \\
(0.974)\end{array}$ & & & $\begin{array}{c}0.113 \\
(0.280)\end{array}$ & \\
\hline landlocked & & $\begin{array}{c}0.544 \\
(0.000)\end{array}$ & & & $\begin{array}{c}0.228 \\
(0.015)\end{array}$ & & & $\begin{array}{l}-0.204 \\
(0.268)\end{array}$ & & & $\begin{array}{l}-0.277 \\
(0.012)\end{array}$ & & & $\begin{array}{c}0.218 \\
(0.004)\end{array}$ & \\
\hline Land near waterways (\%) & & $\begin{array}{c}0.163 \\
(0.284)\end{array}$ & & & $\begin{array}{c}0.136 \\
(0.210)\end{array}$ & & & $\begin{array}{l}-0.220 \\
(0.200)\end{array}$ & & & $\begin{array}{l}-0.101 \\
(0.521)\end{array}$ & & & $\begin{array}{c}0.069 \\
(0.439)\end{array}$ & \\
\hline log GDP per capita & & & $\begin{array}{c}0.272 \\
(0.041)\end{array}$ & & & $\begin{array}{c}0.467 \\
(0.001)\end{array}$ & & & $\begin{array}{l}-0.589 \\
(0.000)\end{array}$ & & & $\begin{array}{c}0.065 \\
(0.671)\end{array}$ & & & $\begin{array}{l}-0.107 \\
(0.314)\end{array}$ \\
\hline Continental FE's & Yes & Yes & Yes & Yes & Yes & Yes & Yes & Yes & Yes & Yes & Yes & Yes & Yes & Yes & Yes \\
\hline Observations & 64 & 64 & 64 & 64 & 64 & 64 & 64 & 64 & 64 & 64 & 64 & 64 & 84 & 84 & 84 \\
\hline R-squared & 0.162 & 0.390 & 0.198 & 0.515 & 0.684 & 0.623 & 0.289 & 0.517 & 0.460 & 0.348 & 0.431 & 0.350 & 0.623 & 0.704 & 0.627 \\
\hline
\end{tabular}


Table 10. The Bounty of the Sea and Personality traits

\begin{tabular}{|c|c|c|c|c|c|c|c|c|c|c|c|c|c|c|c|}
\hline & (1) & (2) & (3) & (4) & (5) & (6) & (7) & (8) & (9) & (10) & (11) & (12) & (13) & (14) & (15) \\
\hline Dep. Var: & 0 & $\mathrm{O}$ & 0 & c & c & c & $\mathrm{E}$ & $\mathrm{E}$ & E & A & A & A & $\mathrm{N}$ & $\mathrm{N}$ & $\mathrm{N}$ \\
\hline \multirow[t]{2}{*}{ Bos Index (ancestry adj) } & 0.509 & 0.630 & 0.543 & -0.341 & -0.221 & -0.310 & 0.182 & 0.167 & 0.097 & 0.139 & 0.466 & 0.128 & -0.197 & -0.128 & -0.239 \\
\hline & $(0.008)$ & $(0.007)$ & $(0.008)$ & $(0.026)$ & $(0.219)$ & $(0.068)$ & $(0.152)$ & $(0.281)$ & $(0.493)$ & $(0.393)$ & $(0.007)$ & $(0.459)$ & $(0.158)$ & $(0.570)$ & $(0.126)$ \\
\hline \multirow[t]{2}{*}{ Soil suitability (ancestry adj) } & -0.050 & -0.091 & -0.069 & 0.037 & 0.002 & 0.020 & -0.087 & -0.149 & -0.041 & -0.277 & -0.330 & -0.271 & -0.113 & -0.193 & -0.090 \\
\hline & $(0.707)$ & $(0.576)$ & $(0.620)$ & $(0.843)$ & $(0.991)$ & $(0.918)$ & $(0.624)$ & $(0.375)$ & $(0.802)$ & $(0.116)$ & $(0.077)$ & $(0.142)$ & $(0.557)$ & $(0.281)$ & $(0.640)$ \\
\hline \multirow[t]{2}{*}{ EEZ area } & 0.314 & 0.511 & 0.310 & 0.028 & 0.146 & 0.025 & -0.336 & -0.250 & -0.327 & -0.129 & 0.224 & -0.128 & 0.087 & 0.324 & 0.092 \\
\hline & $(0.159)$ & $(0.141)$ & $(0.202)$ & $(0.881)$ & $(0.583)$ & $(0.899)$ & $(0.183)$ & $(0.289)$ & $(0.097)$ & $(0.424)$ & $(0.338)$ & $(0.427)$ & $(0.718)$ & $(0.331)$ & $(0.700)$ \\
\hline \multirow[t]{2}{*}{ Land area } & -0.286 & -0.295 & -0.295 & -0.178 & 0.061 & -0.186 & -0.063 & -0.111 & -0.041 & 0.035 & -0.296 & 0.038 & 0.007 & 0.154 & 0.017 \\
\hline & $(0.072)$ & $(0.314)$ & $(0.089)$ & $(0.163)$ & $(0.805)$ & $(0.165)$ & $(0.770)$ & $(0.694)$ & $(0.818)$ & $(0.804)$ & $(0.307)$ & $(0.788)$ & $(0.979)$ & $(0.706)$ & $(0.944)$ \\
\hline \multirow[t]{2}{*}{ Yrs since Neolithic (ancestry adj) } & & 0.328 & & & 0.318 & & & 0.109 & & & 0.265 & & & 0.541 & \\
\hline & & $(0.121)$ & & & $(0.185)$ & & & $(0.473)$ & & & (0.173) & & & $(0.073)$ & \\
\hline \multirow[t]{2}{*}{ Latitude (abs) } & & -0.274 & & & -0.438 & & & 0.338 & & & -0.120 & & & -0.316 & \\
\hline & & $(0.285)$ & & & $(0.033)$ & & & $(0.085)$ & & & (0.574) & & & $(0.287)$ & \\
\hline \multirow[t]{2}{*}{ landlocked } & & 0.101 & & & 0.243 & & & 0.183 & & & 0.553 & & & 0.048 & \\
\hline & & $(0.442)$ & & & (0.159) & & & $(0.235)$ & & & $(0.003)$ & & & $(0.822)$ & \\
\hline \multirow[t]{2}{*}{ Land near waterways (\%) } & & 0.138 & & & 0.454 & & & 0.101 & & & -0.294 & & & 0.487 & \\
\hline & & $(0.593)$ & & & $(0.115)$ & & & $(0.676)$ & & & $(0.340)$ & & & $(0.106)$ & \\
\hline \multirow[t]{2}{*}{ log GDP per capita } & & & -0.135 & & & -0.121 & & & 0.337 & & & 0.047 & & & 0.168 \\
\hline & & & $(0.478)$ & & & $(0.553)$ & & & $(0.057)$ & & & $(0.824)$ & & & $(0.473)$ \\
\hline Continental FE's & Yes & Yes & Yes & Yes & Yes & Yes & Yes & Yes & Yes & Yes & Yes & Yes & Yes & Yes & Yes \\
\hline Observations & 44 & 44 & 44 & 44 & 44 & 44 & 44 & 44 & 44 & 44 & 44 & 44 & 44 & 44 & 44 \\
\hline R-squared & 0.418 & 0.465 & 0.424 & 0.438 & 0.553 & 0.443 & 0.537 & 0.603 & 0.575 & 0.267 & 0.483 & 0.268 & 0.109 & 0.243 & 0.118 \\
\hline
\end{tabular}




\title{
Supplementary Material: The Bounty of the Sea and Long-Run Development
}

\author{
Carl-Johan Dalgaard $\quad$ Anne Sofie Beck Knudsen $\quad$ Pablo Selaya ${ }^{1}$
}

September 10, 2015

${ }^{1}$ Dalgaard: University of Copenhagen and CEPR. Knudsen and Selaya: University of Copenhagen. 


\section{The Bounty of the Sea Index}

The Bounty of the Sea (BoS) index is a measure of the potential abundance of marine fish resources in the oceans. Its construction is essentially a two-step procedure: First the relevant marine fish species are identified using global fish landings statistics from FAO, and second the unweighted average habitat suitability of these species is calculated using gridded data from AquaMaps.

\section{$1.1 \quad$ Identifying the relevant species}

The Fisheries Global Information System (FIGIS) database maintained by FAO contains the collection Global Capture Production, which reports the volume of fish catches landed by country, species, and year for the period 1950-2013. Including landings for commercial, recreational and subsistence purposes, the collection is the most comprehensive of its kind in terms of coverage and quality. The data is available at www.fao.org/fishery/statistics/global-capture-production/en.

The FAO landings data are used to select the marine fish species on which the BoS indices are constructed. The 15 species included in the baseline BoS index are identified as those responsible for the highest reported volume across countries for the period 1950-1959. For an alternative BoS index, however, the top most caught marine fish species in each country of the world is identified. The resulting list of 41 species were thus the most important species in one or more of 91 countries. The geographical distribution of these species cover all continents with 12 being caught mostly by African countries, 13 by countries in the Americas, 8 by Asian countries, 4 by European countries, and 4 by countries in the Oceania.

Details on which species are included in the indices are given in Table A1.

Table A1

\subsection{Computing the average habitat suitability}

Global grids of half-degree cells, predicting the habitat suitability of specific geographic areas for each of the identified marine fish species, are obtained from AquaMaps by Kaschner et al. (2013). Predictions are generated by matching knowledge of the species' habitat usage with local environmental conditions. Knowledge is provided by experts within the field of marine biology ${ }^{1}$

\footnotetext{
${ }^{1}$ In collaboration with FishBase, an online database with detailed information on marine fish species.
} 
and embedded in so-called environmental envelopes.

An environmental envelope is a response curve that describes a species preferences with respect to a group of environmental parameters. In AquaMaps these response curves are of a trapezoidal shape as illustrated in Figure 1. Between the preferred parameter range $\left(\operatorname{Min}_{p}\right.$ to $\left.\operatorname{Max}_{p}\right)$ it assumes that the probability of a given species being present is highest and equal to one. Outside this range, the probability decreases linearly towards the species' absolute minimum and maximum parameter thresholds, beyond which the probability equals zero. The parameter specific probabilities thus lie in the range zero to one.

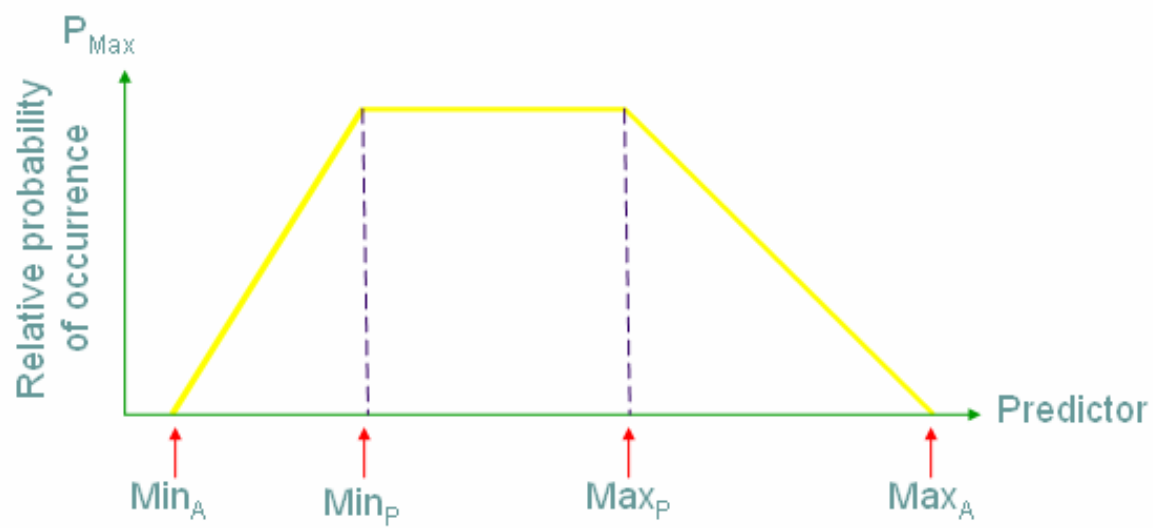

Figure 1: AquaMaps model of a species-specific environmental envelope. Notes: A species will have an envelope for each of the environmental parameters used to predict its occurrence. From Kesner-Reyes et al. (2012).

The environmental parameters incorporated in the envelopes and matching algorithms are sea depth, temperature, salinity, sea ice concentration, and primary production. For demersal fish species that live near the bottom of seas (of which all but one in the BoS index are) temperature and salinity refer to bottom instead of surface values. The underlying environmental data are annual means for periods of 10 years or more, mostly covering the 1980s and 1990s. The overall probability of occurrence for a given species, $P_{c}$, is calculated by mulitplying the environmental parameter specific probabilities according to the following formula:

$$
P_{c}=P_{\text {depth }_{c}} \times P_{\text {temperature }_{c}} \times P_{\text {salinityc }_{c}} \times P_{\text {primaryproduction }_{c}} \times P_{\text {iceconcentration }_{c}}
$$



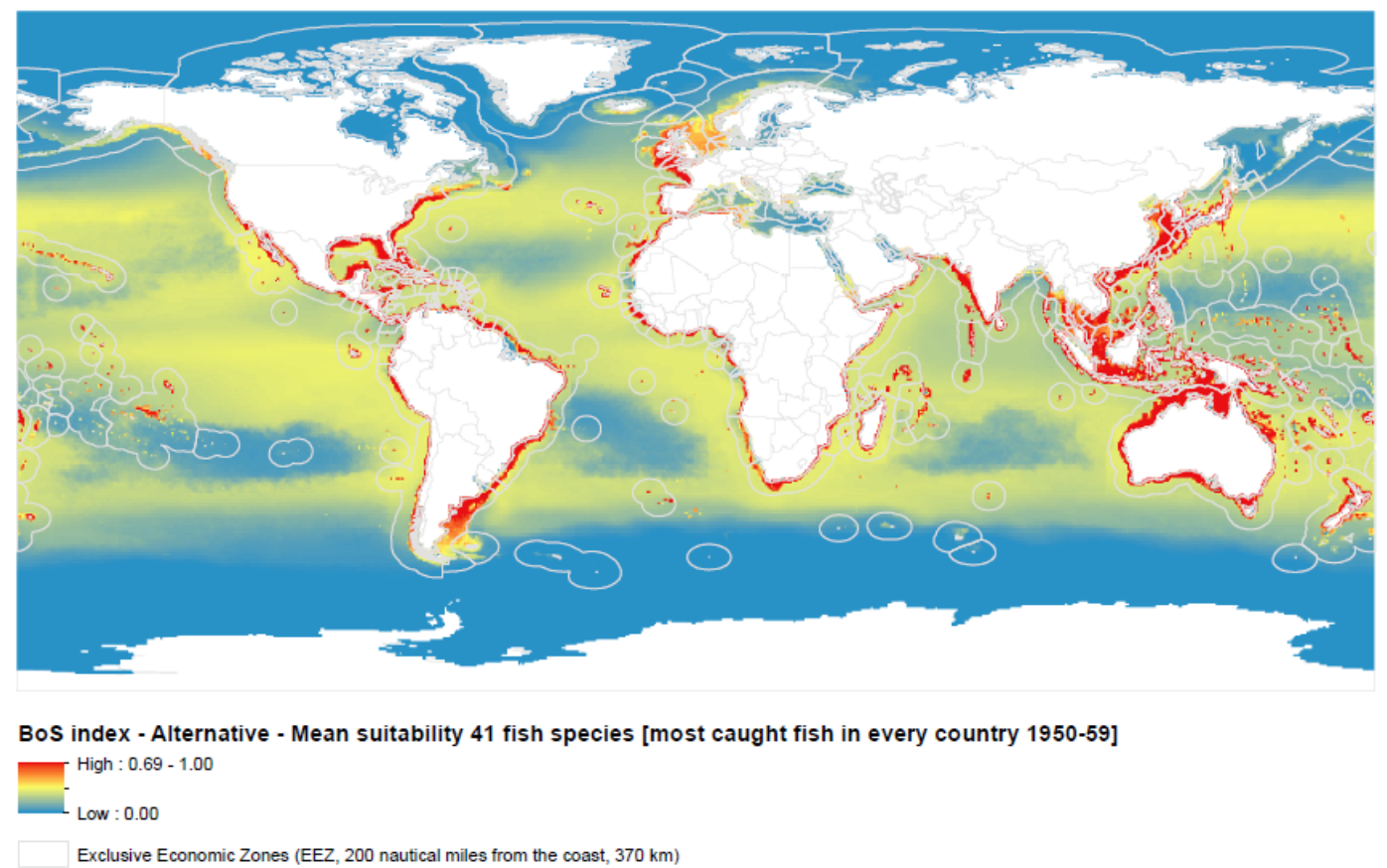

Figure 2: Alternative Bounty of the Sea index. Notes: The index captures the (unweighted) average survival probability for 41 fish species.

The Bounty of the Sea index is consequently calculated as the average probability of occurrence of the 15 identified marine fish species. Likewise, the alternative BoS index is calculated as the average probability of occurrence of the 41 marine fish species. A map of the latter index is presented in Figure 2.

\subsection{Nutrition weighting the BoS index}

Additional alternatives to the baseline BoS index are constructed by nutrition weighting the probabilities of occurrence for each species. Information of nutrition that is comparable across species is obtained from FAO food balance sheets (1989). Values of the yield of edible tissue alon with the fat and protein content is reported here for 130 commercialy important species. Of the 15 species in the BoS index all but three (Gulf menhaden, Atlantic menhaden, and Alaska pollock) are covered by this report. Calorie (kcal), fat, and protein content per gram of edible tissue are used as weights. 


\subsection{Data used for corroborating the BoS index}

The Bounty of the Sea index is validated by assessing its predictive power vis-á-vis actual landings in the $20^{\text {th }}$ century, the allocation of labor during the $19^{\text {th }}$ century, and the contribution from fishing to food supply in traditional societies. The following data sets are used in the exercise:

The FAO FIGIS database already described in Appendix section B.1.1 provides cross country information on actual landings for the periods 1950-1959 and 1960-2009.

Cross country data on 17 European countries ${ }^{2}$ for the period 1903-1949 is collected and provided by the International Council for the Exploration of the Sea (ICES). Only catches of marine fish species are kept in the analysis. Country-year observations with no numerical catch are treated as missing information. Annual average landings are calculated over the period 1903-1939, disregarding World War II years.

Global fish landings statistics for the period 1900-1939 covering 39 countries are collected from three volumes of Mitchell's International Historical Statistics. ${ }^{3}$ The data include landings of both freshwater and marine resources, although marine fish resources make up the majority. Parts of the data suffer from inconsistencies in terms of accounting method. As an example, only landings of cod or herring were recorded for the North Atlantic countries in the early periods. In order to ensure comparability across time and countries, country-year observations like that are discarded.

Data on the allocation of labor is gathered from the North Atlantic Population Project (NAPP), which is adminstrered by the Minnesota Population Center. It contains harmonized census microdata from Canada, Great Britain, Germany, Iceland, Norway, Sweden, and the United States from 1801-1910. The German census data, which just covers the region Mecklenburg-Schwerin, is left out. The individual-level data is aggregated to a level that corresponds to present days first level adminstrative units: States (United States), provinces (Canada), and counties (Norway, Sweden, Iceland, United Kingdom). For each region, the number of fishermen in the population is calculated from the individual occupation $\operatorname{codes}^{4}$, using person weights (variable "perwt"). Likewise, the size

\footnotetext{
${ }^{2}$ The countries are Belgium, Denmark, Faroe Islands, Finland, France, Germany, Greenland, Iceland, Latvia, Netherlands, Norway, Poland, Portugal, Russian Federation, Spain, Sweden, and United Kingdom.

${ }^{3}$ The collections are "Europe 1750-1993" (Denmark, Faeroe Islands, Germany, Iceland, Italy, Netherlands, Norway, Poland, Portugal, Russian Federation, Spain, Sweden, United Kingdom), "Americas 1750-1988" (Argentina, Brazil, Canada, Chile, Cuba, Ecuador, Mexico, Peru, United States), and "Africa, Asia \& Oceania 1750-1988" (Algeria, Angola, Australia, Egypt, Indonesia, Japan, Republic of Korea, Morocco, New Zealand, South Africa, Taiwan, Thailand, Turkey, Venezuela)

${ }^{4} \mathrm{~A}$ person is noted as being involved in fishing if for the US, the variable "occ50us" takes on the value 910
} 
of the total and working population was calculated.

The Ethnographic Atlas (EA) and its sub-collection, the Standard Cross-Cultural Sample (SCCS) by Murdock (1967) and Murdock \& White (1969) respectively, provide information on 1264 and 157 traditional societies respectively. In particular, records of the contribution to food supply of different subsistence strategies are used in the analysis. The variables are v1, v2, v3, v4, and v5 from the EA, and v203, v204, v205, v206, and v207 from the SCCS.

\section{Other Data}

\subsection{Baseline controls (data and description from Ashraf and Galor, 2013)}

- Land suitability for agriculture: Index of land suitability for agriculture, based on indicators of climate, suitability for cultivation (for instance growing degree days and the ratio of actual to potential evapotranspiration) and soil suitability for cultivation (for instance soil carbon density and soil $\mathrm{pH})$.

- Timing of the Neolithic revolution: Years elapsed until the year 2000, since the majority of the population within a country's modern national borders began practicing sedentary agriculture as the primary mode of subsistence. Originally calulated by Putterman (2008).

- Land area: Total land area, from the World Bank's World Development Indicators.

- Continental fixed effects: Indicators for countries belonging to Africa, Asia, America, Europe, or Oceania.

- Absolute latitude: Based on latitude calculated at the centroid of the country, as reported in the CIA's World Factbook.

- Landlocked country: Dummy variable taking the value 1 if the country is landlocked and 0 otherwise.

- Percentage of land area within $100 \mathrm{~km}$ from an ice-free coastline or a navigable navigable river. Originally calculated by Gallup, Sachs and Mellinger (1999).

("Fishermen and oystermen"), for the UK the variable "occgb" takes on the value 121 ("Fisherman"), and for the rest of the countries the variable "occhisco" takes on the value 64100 ("Fishermen"). 


\section{$2.2 \quad$ Additional controls}

- Natural harbors: Harbors sheltered from the wind and sea by virtue of its location within a natural coastal indentation or in the protective lee of an island, cape, reef or other natural barrier (NGA 2015). An example is the harbor of Kingston in Jamaica. Raw data from the US National Geospatial Intelligence Agency, which produces the World Port Index (Pub 150), a dataset containing the location, physical characteristics, facilities and services offered by major ports and oil terminals across the globe. The 2015 version contains 3689 entries, of which 2782 are coastal ports located in 191 countries and territories. We keep all entries related to coastal harbors (i.e., drop all entries related to harbors in rivers or laves), which leaves us with with data for 1177 natural harbours in 173 countries.

- Coastline lenght: km. From Parker (2000).

- Controls in alternative specifications:

- Genetic diversity: Expected heterozygosity (genetic diversity) of a given country as predicted by migratory distance from Addis Ababa, Ethiopia (Ashraf and Galor, 2013)

- Roughness: Average degree of terrain roughness across $1 \mathrm{x} 1$ degree lat lon cells in a country, calculated using geospatial surface undulation data from the G-ECON project (Ashraf and Galor, 2013, originally from Nordhaus, 2006)

- Percentage of arable land: \% of a country's total land area that is arable (Ashraf and Galor, 2013, originally from WB's WDI).

- Temperature: Average monthly temperature, degrees C, 1961-1990, from the GECON dataset (Ashraf and Galor, 2013, originally from Nordhaus, 2006).

- Precipitation: Average monthly precipitation, mm, 1961-1990, from the GECON dataset (Ashraf and Galor, 2013, originally from Nordhaus, 2006).

- Percentage of population of European descent: Fraction of the population in the year 2000 that can trace its ancestral origins to the European continent due to migrations occurring as early as the year 1500 CE. (Ashraf and Galor, 2013, originally constructed using data from the World Migration Matrix, 1500-2000 of Putterman and Weil, 2010). 
- Percentage of population at risk of contracting malaria: Percentage of a country's population in 1994 residing in regions of high malaria risk, multiplied by the proportion of national cases involving the fatal species of the malaria pathogen, P. falciparum, as opposed to other largely nonfatal species (Ashraf and Galor, 2013, originally constructed by Gallup and Sachs, 2001).

- Social infrastructure: Index calculated by Hall and Jones 1999, for the gap between private and social returns to productive activities. The measure is computed as the average of two separate indices. The first is a government anti-diversion policy index based on data from the International Country Risk Guide, across five categories, averaged over 1986-1995: law and order, bureaucratic quality, corruption, risk of expropriation, and government repudiation of contracts. The second is an index of openness, based on Sachs and Warner 1995, representing the fraction of years during 1950-1994 that the economy was open to trade with other countries, which includes nontariff barriers covering less than $40 \%$ of trade, average tariff rates being less than $40 \%$, any black market premium being less than $20 \%$ during the 1970 s and 1980s, the country not being socialist, and the government not monopolizing over major exports. (Ashraf and Galor, 2013)

- OPEC membership indicator (Ashraf and Galor, 2013).

- Share of Roman Catholics, Protestants, and Muslims in the population: (Ashraf and Galor, 2013, originally from La Porta et al.,1999).

- Legal origin fixed effects: British, French, German, Scandinavian, Socialist (Ashraf and Galor, 2013, originally from La Porta et al.,1999).

\subsection{Oceanic controls}

- Ocean biodiversity: Number of known marine fish species with a habitat suitability above 0.5 as computed in Aquamaps (Kaschner et al., 2013).

- Sea area (EEZ or buffer area): Own calculation, based on current boundaries of countries' Exclusive Economic Zones (EEZ), and buffer zones of 10 and $100 \mathrm{~km}$ from the coast of each country into the ocean. 
- Shelf area (\% of EEZ): Share of EEZ area that lies within the shelf zone $(0-200 \mathrm{~m}$ depth). Own calculation.

- Estuary: Share of EEZ area that is covered by estuaries (Kaschner et al., 2013).

- Tide (meters): Average extent of tides along the coastline of a country (Kaschner et al., 2013)

- Small island indicator: From Ashraf and Galor 2011.

- Distance to coast or river: Distance, in thousands of kilometers, from a GIS grid cell to the nearest ice-free coastline or navigable river, averaged across the grid cells of a country (Ashraf and Galor, 2011).

- Ratio of coastline length to land area: Own calculation based on data from Parker (2000).

- Lenght of inland waterways to land area: Own calculation based on Parker (2000).

\subsection{Dependent variables}

- Real GDP per capita 2005: from PWT 8.0.

- Population density in 1500: from Ashraf and Galor (2013).

- Personality traits: Indices from McCrae et al. (2005), for perceived ratings of differences in personality traits across 50 cultures, across the following dimensions:

- (O) Openness to experience: One's propensity to be intellectually curious, appreciative of novelty, interested in art, music,and beauty,and imaginative and creative.

- (C) Conscientiousness: One's propensity to be dutiful, orderly, self-disciplined,deliberate, and achievement striving.

- (E) Extraversion: One's propensity to be gregarious, assertive, friendly, excitementseeking, fast-paced, and high-spirited.

- (A) Agreeableness: One's propensity to be trusting, altruistic; compliant, modest, genuine, and sympathetic toward others. 
- (N) Neuroticism: One's propensity to be stressed, anxious, depressed, angry/hostile, and self-conscious

- Cultural values (decriptions following the Hofstede Centre descriptions of national culture, http://geert-hofstede.com/national-culture.html):

- Masculinity vs femininity:

A measure representing societal preferences for "achievement, heroism, assertiveness and material rewards for success", (associated with masculinity), as compared to preferences for "cooperation, modesty, caring for the weak and quality of life" (associated with femininity). (See Hofstede, 2001).

- Individualism vs collectivism:

Measure of preferences for "a loosely-knit social framework in which individuals are expected to take care of only themselves and their immediate families" (individualism), as opposed to preferences for "a tightly-knit framework in society in which individuals can expect their relatives or members of a particular in-group to look after them in exchange for unquestioning loyalty" (collectivism). (See Hofstede, 2001).

- Power distance:

A measure of hierarchical order in the society, aiming to capture the extent to which the less powerful members accept inequality and expect that power is distributed unevenly, as opposed to societies where people "strive to equalise the distribution of power and demand justification for inequalities of power." (See Hofstede, 2001).

- Uncertainty avoidance:

A measure of the extent to which societies tollerate uncertainty and ambiguity, and of tollerance of unorthodox behavior and ideas, in terms of trying "to control the future or just let it happen". (See Hofstede, 2001).

- Long term orientation vs short term orientation:

Measure of the approach with which societies deal with challenges of the present and the future, for example, by preferring "to maintain time-honoured traditions and norms while viewing societal change with suspicion" as opposed to taking an approach encouraging 
"thrift and efforts in modern education as a way to prepare for the future." (See Hofstede, 2001).

- Institutions (from the Polity IV dataset, averages 1960-2000)

- Constraints on chief executive:

1-7 index reflecting "the extent of institutionalized constraints on the decision making powers of chief executives, whether individuals or collectivities" (Marshall and Jaggers, 2002).

- Institutionalized democracy:

0-10 score reflecting the "presence of institutions and procedures through which citizens can express effective preferences about alternative policies and leaders", "the existence of institutionalized constraints on the exercise of power by the executive", and "the guarantee of civil liberties to all citizens in their daily lives and in acts of political participation" (Marshall and Jaggers, 2002).

- Rule of Law:

-2.5 to 2.5 score from World Bank's World Governance Indicators, average 1996-2013, capturing perceptions of the extent to which agents have confidence in and abide by the rules of society, and in particular the quality of contract enforcement, property rights, the police, and the courts, as well as the likelihood of crime and violence.

\section{Supplementary Results}




\section{References}

[1] Almlund, M., A. L. Duckworth, J. J. Heckman, and T. Kautz, 2011. Personality Psychology and Economics. In E. A. Hanushek, S. Machin, and L. Woessmann (Eds.), Handbook of the Economics of Education, Vol. 4, pp. 1-181. Elsevier B.V.

[2] Kaschner, K., J. Rius-Barile, K. Kesner-Reyes, C. Garilao, S.O. Kullander, T. Rees, and R. Froese. 2013. AquaMaps: Predicted range maps for aquatic species. World wide web electronic publication, www.aquamaps.org, Version 08/2013

[3] Ashraf, Q and O. Galor, 2013. The 'Out of Africa' Hypothesis, Human Genetic Diversity, and Comparative Economic Development. American Economic Review 103, 1-46.

[4] Bouchard, T Jr., and J. C. Loehlin, 2001. Genes, Evolution, and Personality. Behavior Genetics $31,243-73$.

[5] Costa, P. T., and McCrae, R. R., 1992. NEO PI-R professional manual. Odessa: Psychological Assessment Resources.

[6] Digman, J., 1990. Personality Strucgture: Emergence of the Five-Factor Model. Annual Review of Psychology, 41 :417-40

[7] Fisheries Global Information System (FAO-FIGIS) - Web site. About FIGIS. FI Institutional Websites. In: FAO Fisheries and Aquaculture Department [online]. Rome. Updated . [Cited 6 September 2015]. http://www.fao.org/fishery/topic/18043/en

[8] FAO: Torry Research Station, Aberdeen (UK). Yield and nutritional value of the commercially more important fish species. FAO Fisheries Technical Paper. No. 309. Rome, FAO. 1989. 187p.

[9] Gallup, John L., and Jeffrey D. Sachs. 2001. The Economic Burden of Malaria. American Journal of Tropical Medicine and Hygiene 64(1-2): 85-96.

[10] Gallup, John L., Jeffrey D. Sachs, and Andrew D. Mellinger. 1999. "Geography and Economic Development." International Regional Science Review 22(2): 179-232.

[11] Goldberg, L. R., 1993. The Structure of Phenotypic Personality Traits. American Psychologist, 48 (1), $26-34$. 
[12] Hofstede, Geert. 2001. Culture's Consequences: Comparing Values, Behaviors, Institutions, and Organizations Across Nations. Second Edition, Thousand Oaks CA: Sage Publications

[13] Hofstede, G. and R. McCrae, 2004. Personality and culture revisited: Linking traits and dimensions of culture. Cross-Cultural Research 38, 52-88.

[14] ICES Historical Landings 1903-1949. 2014. ICES, Copenhagen

[15] Kapogiannis, D., Sutin, A., Davatzikos, C., Costa, P. T., \& Resnick, S., 2013. The five factors of personality and regional cortical variability in the Baltimore longitudinal study of aging. Human Brain Mapping, 34, 2829-40.

[16] Kaschner, K., J. S. Ready, E. Agbayani, J. Rius, K. Kesner-Reyes, P. D. Eastwood, A. B. South, S. O. Kullander, T. Rees, C. H. Close, R. Watson, D. Pauly, and R. Froese. Editors 2008. AquaMaps Environmental Dataset: Half-Degree Cells Authority File (HCAF). World Wide Web electronic publication, www.aquamaps.org/data, Version 07/2010.

[17] Kesner-Reyes, K., K. Kaschner, S. Kullander, C. Garilao, J. Barile, and R. Froese. 2012. AquaMaps: algorithm and data sources for aquatic organisms. In: Froese, R. and D. Pauly. Editors. 2012. FishBase. World Wide Web electronic publication. www.fishbase.org, version $(04 / 2012)$.

[18] La Porta, Rafael, Florencio Lopez-de-Silanes, Andrei Shleifer, and Robert W. Vishny. 1999. The Quality of Government. Journal of Law, Economics, and Organization 15(1): 222-279.

[19] Marshall, Monty G. and Keith Jaggers (2002), Polity IV Project: Political Regime Characteristics and Transitions, 1800-2002 - Dataset Users' Manual. Available at http://www3.nd.edu/ mcoppedg/crd/PolityIVUsersManualv2002.pdf

[20] McCrae, R.R., 1990. Trait and Trait names: how well is openness to experience represented in natural languages? European Journal of Psychology 4, 119-29.

[21] McCrae, R. R. and O. P. John, 1992. An Introduction to the Five-Factor Model and Its Applications. Journal of Personality 60 (2), 175-215.

[22] Mitchell, B. R. 1993, International historical statistics : the Americas 1750-1988 / B.R. Mitchell Macmillan; Stockton Basingstoke : New York 
[23] Mitchell, B. R. 1995, International historical statistics : Africa, Asia 83 Oceania, 1750-1988 / B.R. Mitchell Macmillan ; Stockton Basingstoke : New York

[24] Mitchell, B. R. 1998, International historical statistics : Europe, 1750-1993 / B.R. Mitchell Macmillan Basingstoke, England

[25] Minnesota Population Center. North Atlantic Population Project: Complete Count Microdata. Version 2.0 [Machine-readable database]. Minneapolis: Minnesota Population Center, 2008

[26] Murdock, G., 1967. Ethnographic atlas. University of Pittsburgh Press

[27] Murdock, George P., and Douglas R. White, 1969. Standard cross-cultural sample. Ethnology (1969): 329-369.

[28] Nordhaus, William D. 2006. Geography and Macroeconomics: New Data and New Findings. Proceedings of the National Academy of Sciences 103(10): 3510-3517.

[29] NGA (US National Geospatial Intelligence Agency), 2015, World Port Index (Pub 150). Available at http://msi.nga.mil/NGAPortal/MSI.portal?_nfpb=true\&_pageLabel=msi_portal_page_62\&pu

[30] Ozer D. and V. Benet-Martínez, 2006. Personality and the prediction of consequential outcomes. Annual Review of Psychology 57, 401-21

[31] Parker, Philip M. (2000), Physioeconomics: The Basis for Long-Run Economic Growth, MIT Press

[32] Terracciano A, Costa PT, McCrae RR (2006): Personality plasticity after age 30. Personality and Social Psychology Bulletin 32, 999-1009. 
Table A1. Most caught marine fish species globally

Marine fish species

Alaska pollock; Atlantic cod; Atlantic herring; Atlantic menhaden; Chub mackerel; European pilchard; Gulf menhaden; Haddock; Japanese anchovy; Largehead hairtail; Pacific herring; Pacific saury; Peruvian anchovy; Pilchards; Saithe

Alaska Pollock; Atlantic cod; Atlantic herring; Atlantic mackerel; Blue whiting; Capelin; Chilean jack mackerel; Chub mackerel; European anchovy; European pilchard; European sprat; Gulf menhaden; Haddock; Japanese anchovy; Largehead hairtail; Pacific herring; Peruvian anchovy; Pilchards; Saithe; Skipjack tuna; Yellowfin tuna

Albacore; Argentine hake; Atlantic Bluefin tuna; Atlantic cod; Atlantic herring; Atlantic menhaden; Australian salmon; Bigeye grunt; Blackfin tuna; Blue marlin; Bonga shad; Brazilian sardinella; Chub mackerel; Cunene horse mackerel; European anchovy; European pilchard; Flathead

Top most caught species in each individual country 1950-59*** grey mullet; Indian mackerel; Indian oil sardine; Indian scad; Kawakawa; Largehead hairtail; Narrowbarred Spanish mackerel; Pacific anchoveta; Pacific saury; Peruvian anchovy; Pilchards; Red grouper; Red hind; Round sardinella; Serra Spanish mackerel; Short mackerel; Silver pomfret; Silver seabream; Skipjack tuna; Slender rainbow sardine; South Pacific hake; Southern red snapper; Surmullet; Unicorn cod; Yellowfin tuna

* These 15 species constituted $52,3 \%$ of the global catch

* These 22 species constituted $52,1 \%$ of the global catch

* These 41 species were the most caught in 91 individual countries 
Table A2. Summary Statistics

\begin{tabular}{|c|c|c|c|c|c|}
\hline & Obs. & Mean & S.D. & Min. & Max. \\
\hline \multicolumn{6}{|l|}{ Main variables and controls: } \\
\hline Population density 1500 C.E. & 184 & 0.88 & 1.42 & -3.82 & 4.14 \\
\hline GDP per capita, 2005 & 166 & 8.70 & 1.32 & 5.41 & 11.42 \\
\hline BoS index & 227 & 0.05 & 0.09 & 0.00 & 0.44 \\
\hline BoS index (ancestry adj) & 165 & 0.07 & 0.09 & 0.00 & 0.43 \\
\hline BoS index, top fish & 227 & 0.14 & 0.10 & 0.00 & 0.42 \\
\hline BoS index, top fish (ancestry adj) & 165 & 0.13 & 0.10 & 0.00 & 0.36 \\
\hline BoS index, $10 \mathrm{~km}$ buffer & 226 & 0.12 & 0.13 & 0.00 & 0.57 \\
\hline Bos Index, 10 km buffer (ancestry adj) & 165 & 0.14 & 0.12 & 0.00 & 0.52 \\
\hline EEZ area & 227 & $5.10 e+20$ & $1.10 \mathrm{e}+21$ & 0.00 & $7.63 e+21$ \\
\hline Buffer area & 226 & 26211.27 & 80611.32 & 0.00 & $8.21 e+05$ \\
\hline Soil suitability & 166 & 0.58 & 0.21 & 0.00 & 1.00 \\
\hline Soil suitability (ancestry adj) & 160 & 0.58 & 0.17 & 0.16 & 0.91 \\
\hline Land area & 211 & $6.14 e+05$ & $1.77 e+06$ & 1.95 & $1.64 \mathrm{e}+07$ \\
\hline Yrs since Neolithic & 164 & 4806.40 & 2432.47 & 362.00 & 10500.00 \\
\hline Yrs since Neolithic (ancestry adj) & 158 & 5448.56 & 2110.90 & 1356.99 & 10400.00 \\
\hline Latitude (abs) & 205 & 25.63 & 17.22 & 1.00 & 72.00 \\
\hline Landlocked & 236 & 0.17 & 0.38 & 0.00 & 1.00 \\
\hline Land near waterways (\%) & 160 & 0.46 & 0.38 & 0.00 & 1.00 \\
\hline \multicolumn{6}{|l|}{ Personality, culture, \& institutions } \\
\hline Big 5: Openness to Experience & 48 & 49.72 & 1.86 & 46.10 & 55.20 \\
\hline Big 5: Concienciousness & 48 & 49.75 & 2.01 & 45.50 & 53.50 \\
\hline Big 5: Extraversion & 48 & 49.70 & 2.46 & 44.40 & 53.90 \\
\hline Big 5: Agreeableness & 48 & 49.60 & 1.78 & 46.10 & 54.20 \\
\hline Big 5: Neurotism & 48 & 49.85 & 1.72 & 46.20 & 53.70 \\
\hline Hofstede: Masculinity & 69 & 48.72 & 19.83 & 5.00 & 110.00 \\
\hline Hofstede: Individualism & 69 & 43.72 & 24.01 & 6.00 & 91.00 \\
\hline Hofstede: Power Distance & 69 & 59.10 & 21.89 & 11.00 & 104.00 \\
\hline Hofstede: Uncertainty Avoidance & 69 & 67.78 & 23.71 & 8.00 & 112.00 \\
\hline Hofstede: Long Term Orientation & 91 & 45.59 & 24.00 & 0.00 & 100.00 \\
\hline Institutions: Constraints on the Executive & 158 & 3.87 & 2.00 & 1.00 & 7.00 \\
\hline Institutions: Democracy & 158 & 3.72 & 3.65 & 0.00 & 10.00 \\
\hline Institutions: Rule of Law & 211 & 0.02 & 0.99 & -2.36 & 1.94 \\
\hline
\end{tabular}


Table A3. The Bounty of the Sea and Pre-Industrial Development: Europe

\begin{tabular}{|c|c|c|c|c|c|c|c|c|c|}
\hline \multirow[b]{2}{*}{ Dep. Var.: (log) } & (1) & (2) & (3) & (4) & (5) & (6) & (7) & (8) & (9) \\
\hline & \multicolumn{9}{|c|}{ Population density 1500 C.E. } \\
\hline \multirow[t]{2}{*}{ BoS index } & 0.361 & 0.321 & 0.588 & & & & & & \\
\hline & $(0.002)$ & $(0.008)$ & $(0.000)$ & & & & & & \\
\hline \multirow[t]{2}{*}{ Bos Index, top fish } & & & & 0.417 & 0.317 & 0.619 & & & \\
\hline & & & & $(0.006)$ & $(0.047)$ & $(0.003)$ & & & \\
\hline \multirow[t]{2}{*}{ BoS index, $10 \mathrm{~km}$ buffer } & & & & & & & 0.322 & 0.357 & 0.448 \\
\hline & & & & & & & $(0.022)$ & $(0.009)$ & $(0.002)$ \\
\hline \multirow[t]{2}{*}{ Soil suitability } & 0.431 & 0.304 & -0.013 & 0.353 & 0.281 & 0.114 & 0.433 & 0.273 & 0.054 \\
\hline & $(0.013)$ & $(0.180)$ & $(0.957)$ & $(0.035)$ & $(0.222)$ & $(0.662)$ & $(0.009)$ & $(0.222)$ & $(0.845)$ \\
\hline \multirow[t]{2}{*}{ EEZ area } & -0.742 & 0.094 & 0.215 & -1.049 & -0.167 & -0.053 & & & \\
\hline & $(0.468)$ & $(0.916)$ & $(0.777)$ & $(0.253)$ & $(0.845)$ & (0.944) & & & \\
\hline \multirow[t]{2}{*}{ Buffer area } & & & & & & & -0.749 & -0.853 & -0.521 \\
\hline & & & & & & & $(0.166)$ & $(0.098)$ & $(0.320)$ \\
\hline \multirow[t]{2}{*}{ Land area } & 0.489 & -0.349 & -0.256 & 0.811 & -0.085 & -0.044 & 0.480 & 0.569 & 0.430 \\
\hline & $(0.627)$ & $(0.693)$ & $(0.742)$ & $(0.369)$ & $(0.920)$ & $(0.955)$ & $(0.360)$ & $(0.254)$ & $(0.418)$ \\
\hline \multirow[t]{2}{*}{ Yrs since Neolithic } & & 0.263 & -0.001 & & 0.198 & 0.128 & & 0.296 & 0.218 \\
\hline & & $(0.069)$ & $(0.992)$ & & $(0.200)$ & $(0.380)$ & & $(0.040)$ & $(0.167)$ \\
\hline \multirow[t]{2}{*}{ Latitude (abs) } & & & -0.584 & & & -0.110 & & & -0.238 \\
\hline & & & $(0.019)$ & & & $(0.608)$ & & & $(0.303)$ \\
\hline \multirow[t]{2}{*}{ landlocked } & & & 0.450 & & & 0.538 & & & 0.366 \\
\hline & & & $(0.008)$ & & & $(0.004)$ & & & $(0.038)$ \\
\hline \multirow[t]{2}{*}{ Land near waterways (\%) } & & & 0.126 & & & 0.099 & & & 0.236 \\
\hline & & & $(0.454)$ & & & $(0.581)$ & & & $(0.154)$ \\
\hline Observations & 37 & 36 & 36 & 37 & 36 & 36 & 37 & 36 & 36 \\
\hline R-squared & 0.391 & 0.475 & 0.678 & 0.425 & 0.460 & 0.640 & 0.352 & 0.488 & 0.618 \\
\hline
\end{tabular}

Notes: standardized regressions coefficients reported; $p$-values in paranthesis. 
Table A4. The Bounty of the Sea and Pre-Industrial Development: Asia.
(1)
(2) (3)
(4)
(5)
(6)
(7)
(8)
(9)

Dep. Var.: (log)

Population density 1500 C.E

\begin{tabular}{|c|c|c|c|c|c|c|c|c|c|}
\hline \multirow[t]{2}{*}{ BoS index } & 0.328 & 0.435 & 0.337 & & & & & & \\
\hline & $(0.005)$ & $(0.001)$ & $(0.019)$ & & & & & & \\
\hline \multirow[t]{2}{*}{ Bos index, top fish } & & & & 0.404 & 0.614 & 0.427 & & & \\
\hline & & & & $(0.007)$ & $(0.000)$ & $(0.048)$ & & & \\
\hline \multirow[t]{2}{*}{ BoS index, $10 \mathrm{~km}$ buffer } & & & & & & & 0.453 & 0.553 & 0.565 \\
\hline & & & & & & & $(0.001)$ & $(0.001)$ & $(0.010)$ \\
\hline \multirow[t]{2}{*}{ Soil suitability } & 0.338 & 0.377 & 0.571 & 0.447 & 0.554 & 0.571 & 0.283 & 0.320 & 0.528 \\
\hline & $(0.016)$ & $(0.004)$ & $(0.000)$ & $(0.000)$ & $(0.000)$ & $(0.000)$ & $(0.045)$ & $(0.015)$ & $(0.000)$ \\
\hline \multirow[t]{2}{*}{ EEZ area } & 0.242 & 0.358 & 0.232 & 0.126 & 0.227 & 0.189 & & & \\
\hline & $(0.119)$ & $(0.033)$ & $(0.274)$ & $(0.444)$ & (0.168) & $(0.300)$ & & & \\
\hline \multirow[t]{2}{*}{ Buffer area } & & & & & & & 0.050 & 0.145 & 0.001 \\
\hline & & & & & & & $(0.486)$ & $(0.080)$ & $(0.994)$ \\
\hline \multirow[t]{2}{*}{ Land area } & -0.084 & -0.195 & -0.184 & -0.080 & -0.240 & -0.189 & -0.015 & -0.107 & -0.110 \\
\hline & $(0.386)$ & $(0.043)$ & $(0.056)$ & $(0.366)$ & $(0.004)$ & $(0.089)$ & $(0.861)$ & $(0.195)$ & $(0.224)$ \\
\hline \multirow[t]{2}{*}{ Yrs since Neoltihic } & & 0.323 & 0.323 & & 0.454 & 0.322 & & 0.309 & 0.414 \\
\hline & & $(0.030)$ & $(0.063)$ & & $(0.002)$ & $(0.059)$ & & $(0.036)$ & $(0.021)$ \\
\hline \multirow[t]{2}{*}{ Latitude (abs) } & & & -0.281 & & & -0.022 & & & -0.443 \\
\hline & & & $(0.245)$ & & & $(0.918)$ & & & $(0.023)$ \\
\hline \multirow[t]{2}{*}{ landlocked } & & & -0.316 & & & -0.247 & & & -0.159 \\
\hline & & & (0.149) & & & $(0.202)$ & & & $(0.437)$ \\
\hline \multirow[t]{2}{*}{ Land near waterways (\%) } & & & -0.143 & & & -0.051 & & & -0.141 \\
\hline & & & $(0.440)$ & & & $(0.753)$ & & & $(0.447)$ \\
\hline Observations & 42 & 42 & 40 & 42 & 42 & 40 & 42 & 42 & 40 \\
\hline R-squared & 0.347 & 0.420 & 0.526 & 0.388 & 0.518 & 0.521 & 0.383 & 0.452 & 0.571 \\
\hline
\end{tabular}

Notes: standardized regressions coefficients reported; $p$-values in paranthesis. 
Table A5. The Bounty of the Sea and Pre-industrial Development: Alternative BoS indices

\begin{tabular}{|c|c|c|c|c|c|c|c|c|}
\hline \multirow[b]{2}{*}{ Dep. Var.: (log) } & (1) & (2) & (3) & (4) & (5) & (6) & (7) & (8) \\
\hline & \multicolumn{8}{|c|}{ Population density 1500 C.E. } \\
\hline \multirow[t]{2}{*}{ BoS index } & 0.187 & 0.183 & & & & & & \\
\hline & $(0.004)$ & $(0.010)$ & & & & & & \\
\hline \multirow[t]{2}{*}{ BoS index (Kcal) } & & & 0.195 & 0.195 & & & & \\
\hline & & & $(0.003)$ & $(0.009)$ & & & & \\
\hline \multirow[t]{2}{*}{ BoS index (Fat) } & & & & & 0.201 & 0.205 & & \\
\hline & & & & & $(0.002)$ & $(0.006)$ & & \\
\hline \multirow[t]{2}{*}{ BoS index (Protein) } & & & & & & & 0.188 & 0.184 \\
\hline & & & & & & & $(0.005)$ & (0.014) \\
\hline \multirow[t]{2}{*}{ Soil suitability } & 0.247 & 0.304 & 0.246 & 0.301 & 0.248 & 0.304 & 0.245 & 0.300 \\
\hline & $(0.000)$ & $(0.000)$ & $(0.000)$ & $(0.000)$ & $(0.000)$ & $(0.000)$ & $(0.000)$ & $(0.000)$ \\
\hline \multirow[t]{2}{*}{ EEZ area } & 0.133 & 0.103 & 0.135 & 0.106 & 0.139 & 0.111 & 0.131 & 0.100 \\
\hline & $(0.274)$ & $(0.403)$ & $(0.267)$ & $(0.391)$ & $(0.255)$ & $(0.370)$ & $(0.283)$ & $(0.417)$ \\
\hline \multirow[t]{2}{*}{ land area } & -0.197 & -0.209 & -0.192 & -0.204 & -0.191 & -0.204 & -0.192 & -0.203 \\
\hline & $(0.061)$ & $(0.068)$ & $(0.068)$ & $(0.074)$ & $(0.070)$ & $(0.075)$ & $(0.069)$ & $(0.076)$ \\
\hline \multirow[t]{2}{*}{ Yrs since Neolithic } & 0.351 & 0.296 & 0.353 & 0.298 & 0.356 & 0.301 & 0.350 & 0.294 \\
\hline & $(0.000)$ & $(0.001)$ & $(0.000)$ & $(0.001)$ & $(0.000)$ & $(0.001)$ & $(0.000)$ & $(0.001)$ \\
\hline \multirow[t]{2}{*}{ Latitude (abs) } & -0.525 & -0.385 & -0.542 & -0.404 & -0.554 & -0.419 & -0.530 & -0.391 \\
\hline & $(0.000)$ & $(0.000)$ & $(0.000)$ & $(0.000)$ & $(0.000)$ & $(0.000)$ & $(0.000)$ & $(0.000)$ \\
\hline \multirow[t]{2}{*}{ landlocked } & 0.074 & & 0.077 & & 0.076 & & 0.076 & \\
\hline & $(0.278)$ & & $(0.262)$ & & $(0.265)$ & & $(0.270)$ & \\
\hline \multirow[t]{2}{*}{ Land near waterways (\%) } & 0.215 & 0.184 & 0.218 & 0.185 & 0.220 & 0.186 & 0.217 & 0.186 \\
\hline & (0.014) & $(0.040)$ & $(0.012)$ & $(0.037)$ & $(0.011)$ & $(0.037)$ & $(0.012)$ & $(0.037)$ \\
\hline Continental FE's & Yes & Yes & Yes & Yes & Yes & Yes & Yes & Yes \\
\hline Sample & Full & No landlock & Full & No landlock & Full & No landlock & Full & No landlock \\
\hline Observations & 150 & 113 & 150 & 113 & 150 & 113 & 150 & 113 \\
\hline R-squared & 0.661 & 0.702 & 0.662 & 0.702 & 0.662 & 0.703 & 0.661 & 0.701 \\
\hline
\end{tabular}

Notes: Standardized regressions coefficients; $p$-values in paranthesis. BoS (Kcal) provides a weighted average of the survival probability for the selected fish species, with weights reflecting the calorie content. BoS (Fat) and BoS (protein) are analogous with weights reflecing fat and protein per edible gram of meat. 
Table A6. Bounty of the Sea and Pre-Industrial Development: Alternative Specifications

$\begin{array}{llllllllllllllll}\text { (1) } & (2) & (3) & (4) & (5) & \text { (6) } & \text { (7) } & \text { (8) } & \text { (9) } & \text { (10) } & \text { (11) } & \text { (12) } & \text { (13) }\end{array}$

Dep. Var.: $(\log )$

Population density 1500 C.E.

\begin{tabular}{|c|c|c|c|c|c|c|c|c|c|c|c|c|c|}
\hline BoS index & $\begin{array}{c}0.265 \\
(0.000)\end{array}$ & $\begin{array}{c}0.158 \\
(0.017)\end{array}$ & $\begin{array}{c}0.139 \\
(0.035)\end{array}$ & $\begin{array}{c}0.147 \\
(0.012)\end{array}$ & $\begin{array}{c}0.119 \\
(0.045)\end{array}$ & $\begin{array}{c}0.144 \\
(0.017)\end{array}$ & $\begin{array}{c}0.140 \\
(0.014)\end{array}$ & $\begin{array}{c}0.176 \\
(0.002)\end{array}$ & $\begin{array}{c}0.214 \\
(0.001)\end{array}$ & & & & \\
\hline Bos index, top fish & & & & & & & & & & $\begin{array}{c}0.120 \\
(0.045)\end{array}$ & $\begin{array}{c}0.106 \\
(0.148)\end{array}$ & & \\
\hline Bos index, $10 \mathrm{~km}$ buffer & & & & & & & & & & & & $\begin{array}{c}0.214 \\
(0.001)\end{array}$ & $\begin{array}{c}0.249 \\
(0.001)\end{array}$ \\
\hline EEZ area & $\begin{array}{l}-0.257 \\
(0.018)\end{array}$ & $\begin{array}{c}-0.212 \\
(0.043)\end{array}$ & $\begin{array}{l}-0.165 \\
(0.100)\end{array}$ & $\begin{array}{c}-0.157 \\
(0.064)\end{array}$ & $\begin{array}{l}-0.100 \\
(0.201)\end{array}$ & $\begin{array}{c}-0.109 \\
(0.144)\end{array}$ & $\begin{array}{c}-0.034 \\
(0.635)\end{array}$ & $\begin{array}{c}-0.022 \\
(0.758)\end{array}$ & $\begin{array}{l}-0.027 \\
(0.727)\end{array}$ & $\begin{array}{c}-0.054 \\
(0.473)\end{array}$ & $\begin{array}{c}-0.089 \\
(0.263)\end{array}$ & & \\
\hline Buffer area & & & & & & & & & & & & $\begin{array}{l}-0.077 \\
(0.085)\end{array}$ & $\begin{array}{l}-0.087 \\
(0.128)\end{array}$ \\
\hline Genetic diversity & $\begin{array}{c}9.314 \\
(0.000)\end{array}$ & $\begin{array}{c}5.510 \\
(0.091)\end{array}$ & $\begin{array}{c}8.699 \\
(0.009)\end{array}$ & $\begin{array}{c}4.067 \\
(0.186)\end{array}$ & $\begin{array}{c}7.313 \\
(0.016)\end{array}$ & $\begin{array}{c}7.245 \\
(0.013)\end{array}$ & $\begin{array}{c}6.022 \\
(0.037)\end{array}$ & $\begin{array}{c}6.131 \\
(0.024)\end{array}$ & $\begin{array}{c}8.244 \\
(0.008)\end{array}$ & $\begin{array}{c}4.642 \\
(0.067)\end{array}$ & $\begin{array}{c}6.818 \\
(0.014)\end{array}$ & $\begin{array}{c}6.110 \\
(0.018)\end{array}$ & $\begin{array}{c}8.702 \\
(0.003)\end{array}$ \\
\hline Genetic diversity sq & $\begin{array}{l}-8.972 \\
(0.000)\end{array}$ & $\begin{array}{l}-5.390 \\
(0.083)\end{array}$ & $\begin{array}{l}-8.672 \\
(0.006)\end{array}$ & $\begin{array}{c}-3.835 \\
(0.186)\end{array}$ & $\begin{array}{l}-7.166 \\
(0.012)\end{array}$ & $\begin{array}{l}-7.187 \\
(0.009)\end{array}$ & $\begin{array}{c}-5.629 \\
(0.040)\end{array}$ & $\begin{array}{c}-5.854 \\
(0.023)\end{array}$ & $\begin{array}{l}-7.859 \\
(0.008)\end{array}$ & $\begin{array}{c}-4.495 \\
(0.065)\end{array}$ & $\begin{array}{c}-6.635 \\
(0.014)\end{array}$ & $\begin{array}{l}-5.726 \\
(0.019)\end{array}$ & $\begin{array}{c}-8.160 \\
(0.004)\end{array}$ \\
\hline Roughness & & & & & & $\begin{array}{c}0.142 \\
(0.034)\end{array}$ & & $\begin{array}{c}0.181 \\
(0.001)\end{array}$ & $\begin{array}{c}0.191 \\
(0.002)\end{array}$ & $\begin{array}{c}0.156 \\
(0.006)\end{array}$ & $\begin{array}{c}0.160 \\
(0.009)\end{array}$ & $\begin{array}{c}0.129 \\
(0.025)\end{array}$ & $\begin{array}{c}0.109 \\
(0.083)\end{array}$ \\
\hline Yrs since Neolithic (log) & & & $\begin{array}{c}0.410 \\
(0.001)\end{array}$ & & $\begin{array}{c}0.450 \\
(0.000)\end{array}$ & $\begin{array}{c}0.422 \\
(0.000)\end{array}$ & $\begin{array}{c}0.465 \\
(0.000)\end{array}$ & $\begin{array}{c}0.411 \\
(0.000)\end{array}$ & $\begin{array}{c}0.387 \\
(0.000)\end{array}$ & $\begin{array}{c}0.421 \\
(0.000)\end{array}$ & $\begin{array}{c}0.415 \\
(0.000)\end{array}$ & $\begin{array}{c}0.404 \\
(0.000)\end{array}$ & $\begin{array}{c}0.401 \\
(0.000)\end{array}$ \\
\hline Areable land (log) & & & & $\begin{array}{c}0.334 \\
(0.000)\end{array}$ & $\begin{array}{c}0.322 \\
(0.000)\end{array}$ & $\begin{array}{c}0.348 \\
(0.000)\end{array}$ & $\begin{array}{c}0.344 \\
(0.000)\end{array}$ & $\begin{array}{c}0.339 \\
(0.000)\end{array}$ & $\begin{array}{c}0.294 \\
(0.000)\end{array}$ & $\begin{array}{c}0.362 \\
(0.000)\end{array}$ & $\begin{array}{c}0.322 \\
(0.000)\end{array}$ & $\begin{array}{c}0.351 \\
(0.000)\end{array}$ & $\begin{array}{c}0.315 \\
(0.000)\end{array}$ \\
\hline Latitude (abs) & & & & $\begin{array}{c}-0.324 \\
(0.000)\end{array}$ & $\begin{array}{l}-0.270 \\
(0.000)\end{array}$ & $\begin{array}{c}-0.282 \\
(0.000)\end{array}$ & $\begin{array}{l}-0.045 \\
(0.628)\end{array}$ & $\begin{array}{c}-0.075 \\
(0.394)\end{array}$ & $\begin{array}{c}0.042 \\
(0.627)\end{array}$ & $\begin{array}{l}-0.063 \\
(0.496)\end{array}$ & $\begin{array}{c}0.049 \\
(0.600)\end{array}$ & $\begin{array}{l}-0.095 \\
(0.253)\end{array}$ & $\begin{array}{c}0.008 \\
(0.906)\end{array}$ \\
\hline Soil suitability (log) & & & & $\begin{array}{c}0.146 \\
(0.153)\end{array}$ & $\begin{array}{c}0.197 \\
(0.021)\end{array}$ & $\begin{array}{c}0.121 \\
(0.189)\end{array}$ & & & & & & & \\
\hline Temperature (log) & & & & & & & $\begin{array}{c}0.238 \\
(0.001)\end{array}$ & $\begin{array}{c}0.292 \\
(0.000)\end{array}$ & $\begin{array}{c}0.311 \\
(0.000)\end{array}$ & $\begin{array}{c}0.205 \\
(0.016)\end{array}$ & $\begin{array}{c}0.182 \\
(0.077)\end{array}$ & $\begin{array}{c}0.241 \\
(0.003)\end{array}$ & $\begin{array}{c}0.261 \\
(0.008)\end{array}$ \\
\hline Percipitation (log) & & & & & & & $\begin{array}{c}0.288 \\
(0.000)\end{array}$ & $\begin{array}{c}0.200 \\
(0.012)\end{array}$ & $\begin{array}{c}0.232 \\
(0.010)\end{array}$ & $\begin{array}{c}0.185 \\
(0.022)\end{array}$ & $\begin{array}{c}0.203 \\
(0.030)\end{array}$ & $\begin{array}{c}0.194 \\
(0.013)\end{array}$ & $\begin{array}{c}0.219 \\
(0.013)\end{array}$ \\
\hline Continent FE & No & Yes & Yes & Yes & Yes & Yes & Yes & Yes & Yes & Yes & Yes & Yes & Yes \\
\hline Sample & Full & Full & Full & Full & Full & Full & Full & Full & No Landlock & Full & No Landlock & Full & No Landlock \\
\hline Observations & 146 & 146 & 146 & 146 & 146 & 146 & 146 & 146 & 111 & 146 & 111 & 146 & 111 \\
\hline R-squared & 0.343 & 0.416 & 0.472 & 0.640 & 0.705 & 0.718 & 0.734 & 0.754 & 0.787 & 0.740 & 0.767 & 0.768 & 0.806 \\
\hline
\end{tabular}

Notes: Standardized regressions coefficients; $p$-values in paranthesis. The underlying standard deviations are robust to HSC. The specifications replicate

Ashraf and Galor (2013, Table 3) 


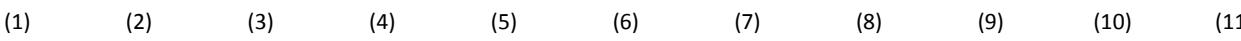

Dep. Var.: $(\log )$

Population density 1500

\begin{tabular}{|c|c|c|c|c|c|c|c|c|c|c|c|}
\hline Bos index & $\begin{array}{c}0.187 \\
(0.004)\end{array}$ & $\begin{array}{c}0.188 \\
(0.004)\end{array}$ & $\begin{array}{c}0.230 \\
(0.000)\end{array}$ & $\begin{array}{c}0.185 \\
(0.010)\end{array}$ & $\begin{array}{c}0.174 \\
(0.030)\end{array}$ & $\begin{array}{c}0.191 \\
(0.004)\end{array}$ & $\begin{array}{c}0.187 \\
(0.004)\end{array}$ & $\begin{array}{c}0.190 \\
(0.003)\end{array}$ & $\begin{array}{c}0.149 \\
(0.044)\end{array}$ & $\begin{array}{c}0.182 \\
(0.013)\end{array}$ & $\begin{array}{c}0.204 \\
(0.022)\end{array}$ \\
\hline Soil suitability & $\begin{array}{c}0.247 \\
(0.000)\end{array}$ & $\begin{array}{c}0.249 \\
(0.000)\end{array}$ & $\begin{array}{c}0.212 \\
(0.001)\end{array}$ & $\begin{array}{c}0.302 \\
(0.000)\end{array}$ & $\begin{array}{c}0.308 \\
(0.000)\end{array}$ & $\begin{array}{c}0.249 \\
(0.000)\end{array}$ & $\begin{array}{c}0.247 \\
(0.000)\end{array}$ & $\begin{array}{c}0.248 \\
(0.000)\end{array}$ & $\begin{array}{c}0.252 \\
(0.000)\end{array}$ & $\begin{array}{c}0.329 \\
(0.000)\end{array}$ & $\begin{array}{c}0.278 \\
(0.003)\end{array}$ \\
\hline EEZ area & $\begin{array}{c}0.133 \\
(0.274)\end{array}$ & $\begin{array}{c}0.135 \\
(0.276)\end{array}$ & $\begin{array}{c}0.083 \\
(0.484)\end{array}$ & $\begin{array}{c}0.107 \\
(0.389)\end{array}$ & $\begin{array}{c}0.102 \\
(0.413)\end{array}$ & $\begin{array}{c}0.122 \\
(0.268)\end{array}$ & $\begin{array}{c}0.132 \\
(0.282)\end{array}$ & $\begin{array}{c}0.131 \\
(0.283)\end{array}$ & $\begin{array}{c}0.143 \\
(0.247)\end{array}$ & $\begin{array}{c}0.101 \\
(0.395)\end{array}$ & $\begin{array}{c}0.047 \\
(0.710)\end{array}$ \\
\hline Land area & $\begin{array}{c}-0.197 \\
(0.061)\end{array}$ & $\begin{array}{l}-0.197 \\
(0.063)\end{array}$ & $\begin{array}{c}-0.166 \\
(0.114)\end{array}$ & $\begin{array}{l}-0.210 \\
(0.069)\end{array}$ & $\begin{array}{c}-0.209 \\
(0.068)\end{array}$ & $\begin{array}{c}-0.192 \\
(0.055)\end{array}$ & $\begin{array}{l}-0.189 \\
(0.102)\end{array}$ & $\begin{array}{c}-0.196 \\
(0.062)\end{array}$ & $\begin{array}{l}-0.202 \\
(0.060)\end{array}$ & $\begin{array}{c}-0.207 \\
(0.063)\end{array}$ & $\begin{array}{c}-0.293 \\
(0.035)\end{array}$ \\
\hline Yrs since Neolithic & $\begin{array}{c}0.351 \\
(0.000)\end{array}$ & $\begin{array}{c}0.348 \\
(0.000)\end{array}$ & $\begin{array}{c}0.325 \\
(0.000)\end{array}$ & $\begin{array}{c}0.290 \\
(0.001)\end{array}$ & $\begin{array}{c}0.296 \\
(0.001)\end{array}$ & $\begin{array}{c}0.364 \\
(0.000)\end{array}$ & $\begin{array}{c}0.349 \\
(0.000)\end{array}$ & $\begin{array}{c}0.350 \\
(0.000)\end{array}$ & $\begin{array}{c}0.365 \\
(0.000)\end{array}$ & $\begin{array}{c}0.300 \\
(0.001)\end{array}$ & $\begin{array}{c}0.266 \\
(0.011)\end{array}$ \\
\hline Latitude (abs) & $\begin{array}{c}-0.525 \\
(0.000)\end{array}$ & $\begin{array}{c}-0.533 \\
(0.000)\end{array}$ & $\begin{array}{c}-0.505 \\
(0.000)\end{array}$ & $\begin{array}{l}-0.388 \\
(0.000)\end{array}$ & $\begin{array}{c}-0.380 \\
(0.000)\end{array}$ & $\begin{array}{l}-0.527 \\
(0.000)\end{array}$ & $\begin{array}{c}-0.521 \\
(0.000)\end{array}$ & $\begin{array}{c}-0.525 \\
(0.000)\end{array}$ & $\begin{array}{l}-0.497 \\
(0.000)\end{array}$ & $\begin{array}{c}-0.392 \\
(0.000)\end{array}$ & $\begin{array}{c}-0.273 \\
(0.016)\end{array}$ \\
\hline Landlocked & $\begin{array}{c}0.074 \\
(0.278)\end{array}$ & $\begin{array}{c}0.069 \\
(0.355)\end{array}$ & $\begin{array}{c}0.014 \\
(0.861)\end{array}$ & & & $\begin{array}{c}0.073 \\
(0.283)\end{array}$ & $\begin{array}{c}0.080 \\
(0.281)\end{array}$ & $\begin{array}{c}0.068 \\
(0.328)\end{array}$ & $\begin{array}{c}0.064 \\
(0.363)\end{array}$ & & \\
\hline Land near waterways (\%) & $\begin{array}{c}0.215 \\
(0.014)\end{array}$ & $\begin{array}{c}0.216 \\
(0.013)\end{array}$ & $\begin{array}{c}0.216 \\
(0.009)\end{array}$ & $\begin{array}{c}0.185 \\
(0.040)\end{array}$ & $\begin{array}{c}0.183 \\
(0.043)\end{array}$ & $\begin{array}{c}0.201 \\
(0.021)\end{array}$ & $\begin{array}{c}0.208 \\
(0.018)\end{array}$ & $\begin{array}{c}0.206 \\
(0.020)\end{array}$ & $\begin{array}{c}0.204 \\
(0.020)\end{array}$ & $\begin{array}{c}0.157 \\
(0.069)\end{array}$ & $\begin{array}{c}0.283 \\
(0.002)\end{array}$ \\
\hline Ocean biodiversity & & $\begin{array}{c}-0.011 \\
(0.903)\end{array}$ & & & & & & & & & $\begin{array}{c}0.064 \\
(0.491)\end{array}$ \\
\hline Shelf area (\% of eez) & & & $\begin{array}{c}-0.151 \\
(0.060)\end{array}$ & & & & & & & & $\begin{array}{c}-0.216 \\
(0.030)\end{array}$ \\
\hline Estuary & & & & $\begin{array}{c}0.030 \\
(0.471)\end{array}$ & & & & & & & $\begin{array}{c}0.056 \\
(0.194)\end{array}$ \\
\hline Tide $(\mathrm{m})$ & & & & & $\begin{array}{c}0.019 \\
(0.743)\end{array}$ & & & & & & $\begin{array}{c}-0.016 \\
(0.776)\end{array}$ \\
\hline Small island & & & & & & $\begin{array}{c}0.041 \\
(0.601)\end{array}$ & & & & & $\begin{array}{c}-0.009 \\
(0.899)\end{array}$ \\
\hline Distance to coast or river & & & & & & & $\begin{array}{c}-0.019 \\
(0.807)\end{array}$ & & & & $\begin{array}{c}0.179 \\
(0.064)\end{array}$ \\
\hline Coastline to land area & & & & & & & & $\begin{array}{c}0.042 \\
(0.052)\end{array}$ & & & $\begin{array}{c}-0.211 \\
(0.041)\end{array}$ \\
\hline Inland waterways to land area & & & & & & & & & $\begin{array}{c}0.078 \\
(0.110)\end{array}$ & & $\begin{array}{c}0.085 \\
(0.092)\end{array}$ \\
\hline Natural ports/area & & & & & & & & & & $\begin{array}{c}0.059 \\
(0.460)\end{array}$ & $\begin{array}{c}0.180 \\
(0.062)\end{array}$ \\
\hline Continental FE's & Yes & Yes & Yes & Yes & Yes & Yes & Yes & Yes & Yes & Yes & Yes \\
\hline Observations & 150 & 150 & 150 & 113 & 113 & 150 & 150 & 150 & 150 & 113 & 113 \\
\hline R-squared & 0.661 & 0.661 & 0.670 & 0.702 & 0.702 & 0.662 & 0.661 & 0.663 & 0.665 & 0.704 & 0.745 \\
\hline
\end{tabular}

Notes: standardized regressions coefficients reported; p-values in paranthesis. 
Table A8. The Ancestral Bounty of the Sea and Contemporary Development: Alternative BoS indices

(1)

(2)

(3)

(4)

(5)

(6)

(7)

(8)

Dep. Var.: (log)

GDP per capita 2005

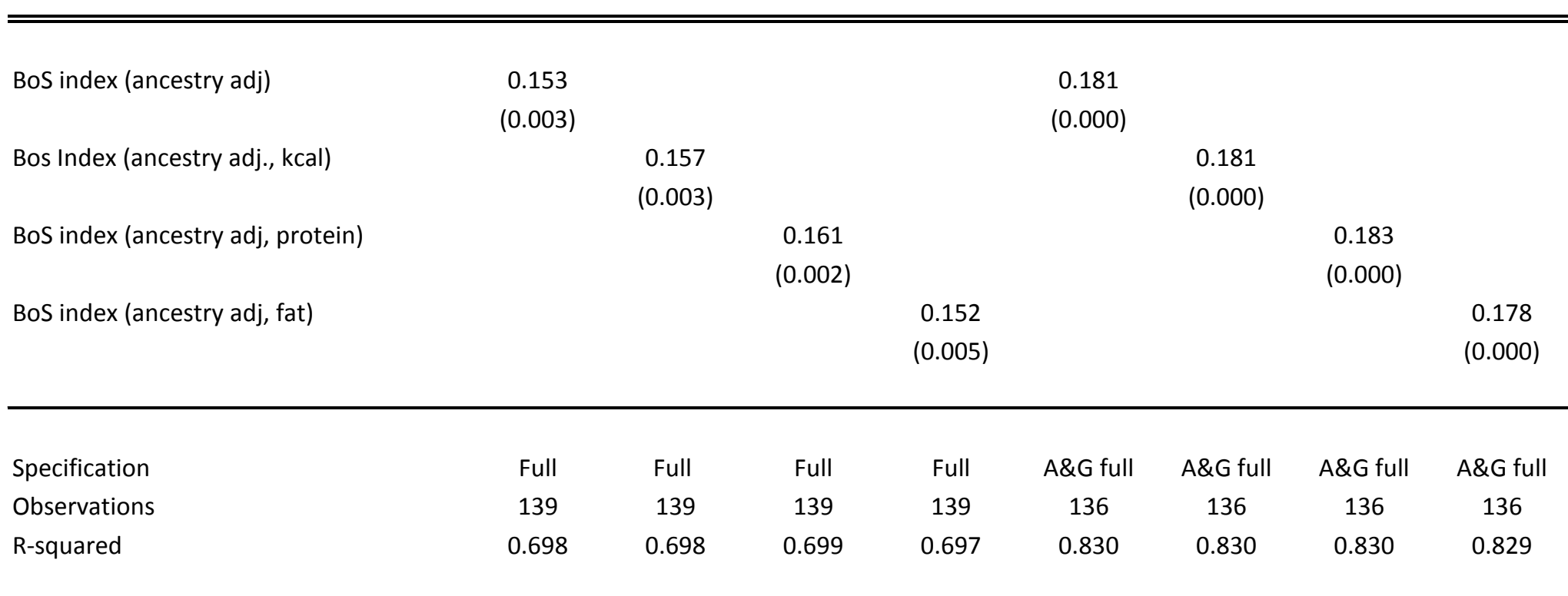

Notes: Standardized regressions coefficients; p-values in paranthesis. BoS (Kcal) provides a weighted average

of the survival probability for the selected fish species, with weights reflecting the calorie content. BoS (Fat) and

BoS (protein) are analogous with weights reflecing fat and protein per edible gram of meat. In the first four cls

we control for our full baseline set of variables; see Table X column 5. In the last four cls we include the set of controls

adopted by Ashraf and Galor (2013, Table 7), except for Social Infrastructure. Hence the controls are those present in

Table A9, column 10 


$\begin{array}{llllllllll}\text { (1) } & \text { (2) } & \text { (3) } & \text { (4) } & \text { (5) } & \text { (6) } & \text { (7) } & \text { (8) } & \text { (9) } & \text { (10) }\end{array}$

Dep. Var.: (log)

GDP per capita 2005

\begin{tabular}{|c|c|c|c|c|c|c|c|c|c|c|c|}
\hline BoS index (ancestry adj) & $\begin{array}{c}0.158 \\
(0.002)\end{array}$ & $\begin{array}{c}0.162 \\
(0.002)\end{array}$ & $\begin{array}{c}0.167 \\
(0.006)\end{array}$ & $\begin{array}{c}0.200 \\
(0.001)\end{array}$ & $\begin{array}{c}0.215 \\
(0.005)\end{array}$ & $\begin{array}{c}0.157 \\
(0.004)\end{array}$ & $\begin{array}{c}0.154 \\
(0.002)\end{array}$ & $\begin{array}{c}0.161 \\
(0.002)\end{array}$ & $\begin{array}{c}0.201 \\
(0.001)\end{array}$ & $\begin{array}{c}0.210 \\
(0.000)\end{array}$ & $\begin{array}{c}0.213 \\
(0.010)\end{array}$ \\
\hline Soil suitability (ancestry adj) & $\begin{array}{c}-0.213 \\
(0.000)\end{array}$ & $\begin{array}{l}-0.205 \\
(0.001)\end{array}$ & $\begin{array}{c}-0.218 \\
(0.000)\end{array}$ & $\begin{array}{l}-0.260 \\
(0.001)\end{array}$ & $\begin{array}{c}-0.263 \\
(0.001)\end{array}$ & $\begin{array}{l}-0.213 \\
(0.000)\end{array}$ & $\begin{array}{c}-0.218 \\
(0.000)\end{array}$ & $\begin{array}{c}-0.214 \\
(0.000)\end{array}$ & $\begin{array}{l}-0.217 \\
(0.000)\end{array}$ & $\begin{array}{c}-0.234 \\
(0.003)\end{array}$ & $\begin{array}{l}-0.215 \\
(0.004)\end{array}$ \\
\hline EEZ area & $\begin{array}{c}0.137 \\
(0.109)\end{array}$ & $\begin{array}{c}0.154 \\
(0.054)\end{array}$ & $\begin{array}{c}0.127 \\
(0.140)\end{array}$ & $\begin{array}{c}0.157 \\
(0.165)\end{array}$ & $\begin{array}{c}0.175 \\
(0.135)\end{array}$ & $\begin{array}{c}0.138 \\
(0.103)\end{array}$ & $\begin{array}{c}0.129 \\
(0.136)\end{array}$ & $\begin{array}{c}0.135 \\
(0.117)\end{array}$ & $\begin{array}{c}0.127 \\
(0.139)\end{array}$ & $\begin{array}{c}0.171 \\
(0.126)\end{array}$ & $\begin{array}{c}0.244 \\
(0.063)\end{array}$ \\
\hline Land area & $\begin{array}{c}-0.053 \\
(0.512)\end{array}$ & $\begin{array}{l}-0.054 \\
(0.507)\end{array}$ & $\begin{array}{c}-0.047 \\
(0.554)\end{array}$ & $\begin{array}{l}-0.078 \\
(0.453)\end{array}$ & $\begin{array}{c}-0.083 \\
(0.431)\end{array}$ & $\begin{array}{c}-0.053 \\
(0.509)\end{array}$ & $\begin{array}{c}0.012 \\
(0.884)\end{array}$ & $\begin{array}{c}-0.053 \\
(0.516)\end{array}$ & $\begin{array}{l}-0.049 \\
(0.538)\end{array}$ & $\begin{array}{c}-0.082 \\
(0.434)\end{array}$ & $\begin{array}{c}0.134 \\
(0.303)\end{array}$ \\
\hline Yrs since Neolithic (ancestry adj) & $\begin{array}{c}0.169 \\
(0.021)\end{array}$ & $\begin{array}{c}0.141 \\
(0.077)\end{array}$ & $\begin{array}{c}0.166 \\
(0.026)\end{array}$ & $\begin{array}{c}0.245 \\
(0.004)\end{array}$ & $\begin{array}{c}0.231 \\
(0.009)\end{array}$ & $\begin{array}{c}0.168 \\
(0.024)\end{array}$ & $\begin{array}{c}0.154 \\
(0.041)\end{array}$ & $\begin{array}{c}0.167 \\
(0.022)\end{array}$ & $\begin{array}{c}0.153 \\
(0.028)\end{array}$ & $\begin{array}{c}0.231 \\
(0.008)\end{array}$ & $\begin{array}{c}0.144 \\
(0.084)\end{array}$ \\
\hline Latitude (abs) & $\begin{array}{c}0.390 \\
(0.000)\end{array}$ & $\begin{array}{c}0.335 \\
(0.001)\end{array}$ & $\begin{array}{c}0.395 \\
(0.000)\end{array}$ & $\begin{array}{c}0.366 \\
(0.001)\end{array}$ & $\begin{array}{c}0.351 \\
(0.002)\end{array}$ & $\begin{array}{c}0.390 \\
(0.000)\end{array}$ & $\begin{array}{c}0.424 \\
(0.000)\end{array}$ & $\begin{array}{c}0.389 \\
(0.000)\end{array}$ & $\begin{array}{c}0.366 \\
(0.000)\end{array}$ & $\begin{array}{c}0.345 \\
(0.001)\end{array}$ & $\begin{array}{c}0.148 \\
(0.309)\end{array}$ \\
\hline Landlocked & $\begin{array}{c}0.013 \\
(0.833)\end{array}$ & $\begin{array}{l}-0.023 \\
(0.770)\end{array}$ & $\begin{array}{c}-0.001 \\
(0.993)\end{array}$ & & & $\begin{array}{c}0.013 \\
(0.834)\end{array}$ & $\begin{array}{c}0.058 \\
(0.408)\end{array}$ & $\begin{array}{c}0.008 \\
(0.906)\end{array}$ & $\begin{array}{c}0.022 \\
(0.734)\end{array}$ & & \\
\hline Land near waterways (\%) & $\begin{array}{c}0.182 \\
(0.058)\end{array}$ & $\begin{array}{c}0.193 \\
(0.050)\end{array}$ & $\begin{array}{c}0.181 \\
(0.064)\end{array}$ & $\begin{array}{c}0.146 \\
(0.130)\end{array}$ & $\begin{array}{c}0.148 \\
(0.136)\end{array}$ & $\begin{array}{c}0.183 \\
(0.083)\end{array}$ & $\begin{array}{c}0.130 \\
(0.186)\end{array}$ & $\begin{array}{c}0.173 \\
(0.075)\end{array}$ & $\begin{array}{c}0.193 \\
(0.048)\end{array}$ & $\begin{array}{c}0.106 \\
(0.291)\end{array}$ & $\begin{array}{l}-0.010 \\
(0.929)\end{array}$ \\
\hline Ocean biodiversity & & $\begin{array}{l}-0.085 \\
(0.349)\end{array}$ & & & & & & & & & $\begin{array}{c}-0.270 \\
(0.012)\end{array}$ \\
\hline Shelf area (\% of eez area) & & & $\begin{array}{c}-0.031 \\
(0.723)\end{array}$ & & & & & & & & $\begin{array}{c}0.054 \\
(0.603)\end{array}$ \\
\hline Estuary & & & & $\begin{array}{l}-0.112 \\
(0.003)\end{array}$ & & & & & & & $\begin{array}{l}-0.132 \\
(0.007)\end{array}$ \\
\hline Tides $(\mathrm{m})$ & & & & & $\begin{array}{c}-0.014 \\
(0.832)\end{array}$ & & & & & & $\begin{array}{c}0.043 \\
(0.509)\end{array}$ \\
\hline Small island & & & & & & $\begin{array}{c}-0.002 \\
(0.976)\end{array}$ & & & & & $\begin{array}{c}-0.032 \\
(0.708)\end{array}$ \\
\hline Distance to coast or river & & & & & & & $\begin{array}{l}-0.154 \\
(0.040)\end{array}$ & & & & $\begin{array}{l}-0.345 \\
(0.013)\end{array}$ \\
\hline Coastline/area & & & & & & & & $\begin{array}{c}0.039 \\
(0.075)\end{array}$ & & & $\begin{array}{c}0.130 \\
(0.160)\end{array}$ \\
\hline Indland waterways/area & & & & & & & & & $\begin{array}{c}-0.080 \\
(0.095)\end{array}$ & & $\begin{array}{l}-0.058 \\
(0.206)\end{array}$ \\
\hline Natural ports/area & & & & & & & & & & $\begin{array}{c}0.096 \\
(0.009)\end{array}$ & $\begin{array}{c}0.022 \\
(0.734)\end{array}$ \\
\hline Continental FE's & yes & Yes & Yes & Yes & Yes & Yes & Yes & Yes & Yes & Yes & Yes \\
\hline Observations & 139 & 139 & 139 & 102 & 102 & 139 & 139 & 139 & 139 & 102 & 102 \\
\hline R-squared & 0.702 & 0.704 & 0.702 & 0.712 & 0.700 & 0.702 & 0.711 & 0.703 & 0.706 & 0.707 & 0.764 \\
\hline
\end{tabular}

Notes: Standardized regression coefficients; p-values in paranthesis. 
Table A10. Ancestral Bounty of the Sea and Comparative Development: Alternative Specification

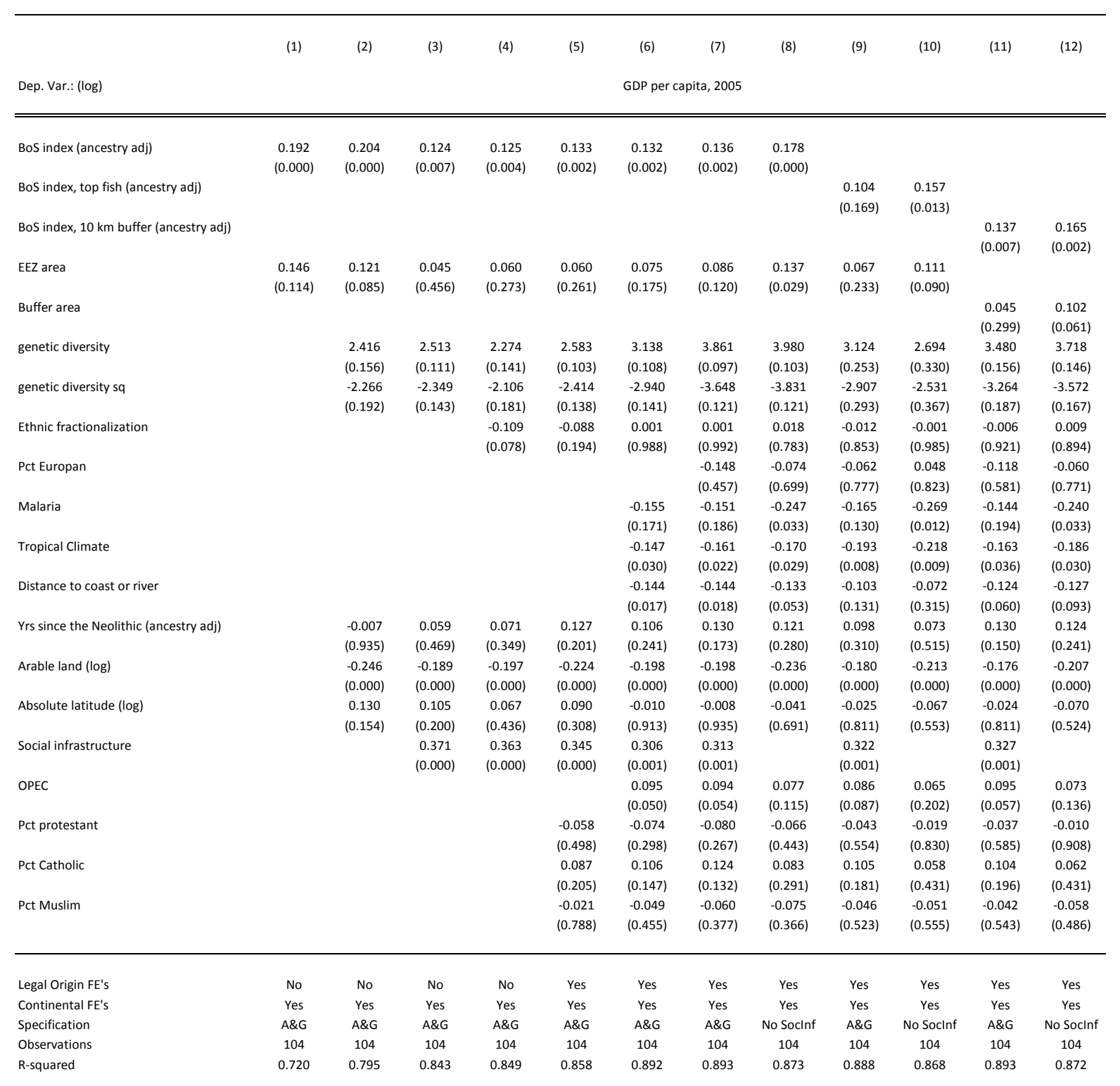

Notes: standardized regression coefficients; $\mathrm{p}$ values in paranthesis. Underlying standard errors robust to heteroscedasticity. In columns marked "No Soclnf" we omit social infrastructure from the model.

The specifications replicate Ashraf and Galor (2013, Table 7). Legal origins include: British, French, Scandinavian and German 
Dep. Var.: (log)

\begin{tabular}{|c|c|c|c|c|c|c|c|c|c|c|c|c|}
\hline BoS index (ancestry adj) & $\begin{array}{l}0.332 \\
(0.034)\end{array}$ & $\begin{array}{l}0.347 \\
(0.006)\end{array}$ & $\begin{array}{c}0.143 \\
(0.172)\end{array}$ & $\begin{array}{l}0.169 \\
(0.089)\end{array}$ & $\begin{array}{c}0.173 \\
(0.105)\end{array}$ & $\begin{array}{l}0.279 \\
(0.012)\end{array}$ & $\begin{array}{c}0.273 \\
(0.024)\end{array}$ & $\begin{array}{l}0.399 \\
(0.001)\end{array}$ & & & & \\
\hline \multirow{2}{*}{ Bos index } & -0.146 & -0.148 & -0.020 & -0.044 & -0.039 & -0.145 & -0.135 & -0.225 & & & & \\
\hline & $(0.328)$ & $(0.170)$ & $(0.818)$ & $(0.586)$ & $(0.645)$ & $(0.106)$ & $(0.186)$ & $(0.046)$ & & & & \\
\hline Bos index, top fish (ancestry adj) & & & & & & & & & $\begin{array}{l}0.171 \\
0.2121\end{array}$ & $\begin{array}{l}0.234 \\
0.0571\end{array}$ & & \\
\hline \multirow[t]{2}{*}{ Bos index, top fish } & & & & & & & & & -0.078 & -0.089 & & \\
\hline & & & & & & & & & $(0.477)$ & $(0.426)$ & & \\
\hline BoS index, 10 km buffer (ancestry adj) & & & & & & & & & & & $\begin{array}{c}0.196 \\
(0.051)\end{array}$ & $\begin{array}{c}0.252 \\
(0.013)\end{array}$ \\
\hline Bos index, $10 \mathrm{~km}$ buffer & & & & & & & & & & & $\begin{array}{l}-0.060 \\
(0.418)\end{array}$ & $\begin{array}{l}-0.090 \\
(0.282)\end{array}$ \\
\hline \multirow[t]{2}{*}{ EEZ area } & 0.132 & 0.108 & 0.044 & 0.057 & 0.058 & 0.069 & 0.078 & 0.117 & 0.068 & 0.112 & & \\
\hline & $(0.155)$ & $(0.151)$ & $(0.475)$ & $(0.306)$ & $(0.286)$ & $(0.200)$ & $(0.159)$ & $(0.050)$ & $(0.234)$ & $(0.089)$ & & \\
\hline Buffer area & & & & & & & & & & & 0.040 & $\begin{array}{c}0.093 \\
1.088\end{array}$ \\
\hline \multirow[t]{2}{*}{ Genetic diversity } & & 2.700 & 2.550 & 2.352 & 2.648 & 3.366 & 3.917 & 4.059 & 3.370 & 2.979 & 3.455 & $\begin{array}{l}3.0801 \\
3.681\end{array}$ \\
\hline & & $(0.114)$ & $(0.111)$ & $(0.134)$ & $(0.100)$ & $(0.089)$ & $(0.095)$ & $(0.102)$ & $(0.205)$ & $(0.277)$ & $(0.159)$ & $(0.149)$ \\
\hline \multirow[t]{2}{*}{ Genetic diversity sq } & & -2.553 & -2.387 & -2.184 & -2.477 & -3.158 & -3.699 & -3.893 & -3.147 & -2.808 & -3.244 & -3.540 \\
\hline & & $(0.142)$ & $(0.143)$ & $(0.171)$ & $(0.133)$ & $(0.118)$ & $(0.119)$ & $(0.120)$ & $(0.242)$ & $(0.311)$ & $(0.190)$ & $(0.169)$ \\
\hline \multirow{2}{*}{ Ethnic fractionalization } & & & & -0.112 & -0.090 & -0.007 & -0.007 & 0.003 & -0.007 & 0.004 & -0.007 & 0.008 \\
\hline & & & & $(0.075)$ & $(0.188)$ & $(0.914)$ & $(0.918)$ & $(0.960)$ & (0.914) & $(0.948)$ & (0.919) & $(0.902)$ \\
\hline \multirow{2}{*}{ Pct Europan } & & & & & & & -0.117 & -0.031 & -0.065 & 0.044 & -0.111 & $\begin{array}{l}0.0021 \\
-0.051\end{array}$ \\
\hline & & & & & & & (0.584) & $(0.878)$ & $(0.765)$ & $(0.839)$ & $(0.615)$ & $(0.811)$ \\
\hline \multirow[t]{2}{*}{ Malaria } & & & & & & -0.127 & -0.125 & $\begin{array}{l}0.191 \\
-0.192\end{array}$ & -0.152 & $\begin{array}{l}0.0373 \\
-0.253\end{array}$ & -0.129 & $\begin{array}{l}-0.218 \\
-0.218\end{array}$ \\
\hline & & & & & & $(0.278)$ & $(0.288)$ & $(0.108)$ & $(0.187)$ & $(0.020)$ & $(0.280)$ & $(0.067)$ \\
\hline \multirow{2}{*}{ Tropical climate } & & & & & & -0.176 & -0.185 & -0.209 & -0.203 & -0.228 & -0.175 & -0.203 \\
\hline & & & & & & $(0.013)$ & $(0.010)$ & $(0.009)$ & $(0.007)$ & $(0.006)$ & $(0.026)$ & $(0.019)$ \\
\hline \multirow{2}{*}{ Distance to coast or river } & & & & & & -0.165 & -0.164 & -0.168 & -0.117 & -0.088 & -0.132 & -0.138 \\
\hline & & & & & & $(0.010)$ & $(0.012)$ & $(0.021)$ & $(0.102)$ & $(0.242)$ & $(0.050)$ & $(0.075)$ \\
\hline \multirow{2}{*}{ Yrs since Neolithic (ancestry adj) } & & 0.009 & 0.061 & 0.075 & 0.130 & 0.117 & 0.136 & 0.131 & 0.105 & 0.081 & 0.138 & 0.135 \\
\hline & & $(0.921)$ & $(0.466)$ & $(0.332)$ & $(0.201)$ & $(0.196)$ & $(0.152)$ & $(0.226)$ & $(0.283)$ & $(0.476)$ & $(0.135)$ & $(0.211)$ \\
\hline \multirow{2}{*}{ Arable land (log) } & & -0.243 & -0.189 & -0.198 & -0.224 & -0.194 & -0.194 & & & & & -0.201 \\
\hline & & $(0.000)$ & $(0.000)$ & $(0.000)$ & $(0.000)$ & $(0.000)$ & $(0.000)$ & $(0.000)$ & $(0.000)$ & $(0.000)$ & $(0.000)$ & $(0.000)$ \\
\hline \multirow{2}{*}{ Absolute latitude (log) } & & 0.127 & 0.104 & 0.065 & 0.090 & -0.024 & -0.022 & -0.060 & -0.039 & -0.083 & -0.031 & $\begin{array}{l}0.0080 \\
-0.080\end{array}$ \\
\hline & & $(0.161)$ & $(0.203)$ & $(0.449)$ & $(0.311)$ & $(0.793)$ & $(0.820)$ & $(0.552)$ & $(0.715)$ & $(0.462)$ & $(0.753)$ & $(0.458)$ \\
\hline \multirow[t]{2}{*}{ Social infrastructure } & & & 0.368 & 0.356 & 0.338 & 0.282 & 0.289 & & 0.321 & & 0.324 & \\
\hline & & & $(0.000)$ & $(0.000)$ & $(0.000)$ & $(0.002)$ & $(0.003)$ & & $(0.001)$ & & $(0.001)$ & \\
\hline \multirow[t]{2}{*}{ OPEC } & & & & & & 0.096 & 0.096 & 0.082 & 0.087 & 0.066 & 0.096 & 0.075 \\
\hline & & & & & & $(0.045)$ & $(0.049)$ & $(0.088)$ & $(0.083)$ & $(0.191)$ & $(0.058)$ & $(0.129)$ \\
\hline \multirow{2}{*}{ Pct Protestant } & & & & & -0.062 & -0.084 & -0.089 & -0.082 & -0.048 & -0.025 & -0.034 & -0.006 \\
\hline & & & & & $(0.474)$ & $(0.240)$ & $(0.226)$ & $(0.330)$ & (0.526) & $(0.788)$ & $(0.619)$ & $(0.946)$ \\
\hline Pct Catholic & & & & & 0.087 & 0.110 & 0.124 & 0.087 & 0.107 & 0.061 & 0.106 & 0.065 \\
\hline Pli lationit & & & & & $\begin{array}{l}(0.208) \\
(108)\end{array}$ & (0.125) & $\begin{array}{l}(0.125) \\
(124)\end{array}$ & $(0.245)$ & $(0.165)$ & $\begin{array}{l}.0 .009) \\
(0.49\end{array}$ & $\begin{array}{l}.0 .185) \\
(0)\end{array}$ & $(0.414)$ \\
\hline Pct Muslim & & & & & -0.023 & -0.055 & -0.063 & -0.079 & -0.040 & -0.045 & -0.040 & -0.055 \\
\hline & & & & & $(0.772)$ & $(0.381)$ & $(0.334)$ & $(0.310)$ & (0.573) & $(0.601)$ & $(0.559)$ & $(0.503)$ \\
\hline al ori & № & No & No & No & Yes & Yes & Yes & Yes & Yes & Yes & Yes & Yes \\
\hline $\operatorname{tin} \epsilon_{-1}$ & Yes & Yes & Yes & Yes & Yes & Yes & Yes & Yes & Yes & Yes & Yes & Yes \\
\hline cific: & $A \& G$ & $A \& G$ & A\&G & $A \& G$ & A\&G & $A \& G$ & A\&G & No Socinf & A\&G & No Soclinf & $A \& G$ & lo Socinf \\
\hline ervation & 104 & 104 & 104 & 104 & 10 & 104 & 104 & n & 10 & 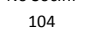 & 104 & 1 \\
\hline R-squared & 0.723 & 0.798 & 0.843 & 0.849 & 0.858 & 0.894 & 0.895 & 0.879 & 0.889 & 0.869 & 0.893 & 0.873 \\
\hline
\end{tabular}

Notes: standardized regression coefficients; p values in paranthesis. Underlying standard errors robust to heteroscedasticity. All specifications involve a constant. In columns 